\title{
TÉCNICA CULTURAL PARA O CONTROLE DA PODRIDÃO-ABACAXI EM CANA-DE-AÇÚCAR E MODELO PARA ESTIMATIVA DE PERDAS
}

\author{
ANTONIO CARLOS A. GHELLER \\ Engenheiro Agrônomo
}

Orientador : Prof. Dr. Antonio Luiz Fancelli

Tese apresentada à Escola Superior de Agricultura "Luiz de Queiroz", da Universidade de São Paulo, para obtenção do título de Doutor em Agronomia, Área de Concentração: Fitotecnia.

PIRACICABA

Estado de São Paulo - Brasil

Julho - 1995 
Sheller, Antonio Carlas A.

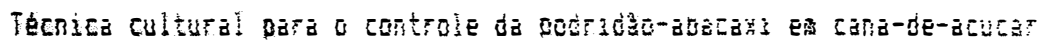
e modelo odra estimativa de perdas. Firacicata. 19g5.

135.

TESE - ESALE

Gibijogratia.

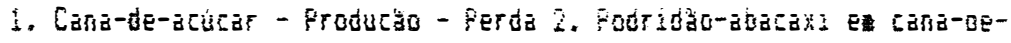
acucar - Controle i. Funoo fitudatooenica l. Eecola Superiar de Aoracultura luiz de Bueiroz. Fisacacaba 


\title{
TÉCNICA CULTURAL PARA O CONTROLE DA PODRIDÃO-ABACAXI EM CANA-DE-AÇÚCAR E MODELO PARA ESTIMATIVA DE PERDAS
}

\author{
ANTONIO CARLOS A. GHELLER \\ Engenheiro Agrônomo
}

Aprovada em : 04 de Setembro de 1995

Comissão julgadora:

Prof. Dr. Antonio Luiz Fancelli

ESALQ / USP

Prof. Dr. Hasime Tokeshi

ESALQ / USP

Prof. Dr. Sizuo Matsuoka

ESALQ / USP

Prof. Dr. Rubismar Stolf

CCA / UFSCar

Prof. Dr.José Carlos Casagrande

CCA / UFSCar

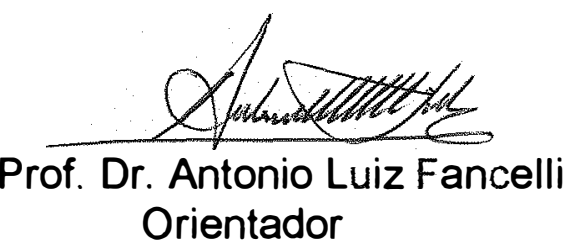


Aos meus pais Antonio (em memória) e Almehy, pelo exemplo e ensinamentos que orientaram nossos passos, como também os dos manos José, Paulo, Miriam e Valentim, cuja amizade e solidariedade tive sempre ao lado

À Christina e às garotas

Christiane,

Carolina e

Fernanda,

a motivação para seguir adiante 


\section{AGRADECIMENTOS}

À Universidade Federal de São Carlos, pelo amparo institucional que permitiu a continuidade das atividades de pesquisa estruturadas para 0 setor canavieiro, e consequentemente, da nossa carreira profissional.

Ao IAAPLANALSUCAR, na evocação daqueles que 0 construiram, pela oportunidade de participar do desenvolvimento tecnológico canavieiro do País.

Ao IAAPLANALSUCAR, no obscurantismo daqueles que 0 destruiram, prejudicado pela miopia de alguns dos seus dirigentes e do setor público ao qual estava vinculado, por nos proporcionar a grata satisfação de constatar que, apesar de tudo, o trabalho fundamentado, estruturado em equipe, administrado com zelo e dedicação, jamais será destruido. A realidade do setor canavieiro atual, na forma de aplicação de tantas tecnologias geradas pelo IAAPLANALSUCAR, como notadamente, as VARIEDADES RB, testemunham concretamente tal fato; a continuidade de alguns dos seus objetivos, evitou prejuizo maior ao produtor canavieiro, o que não foi levado em consideração por aqueles que conduziram a sua extinção.

Ao colega, amigo e companheiro de tantas batalhas, Prof. Dr. Sizuo Matsuoka, pelas oportunidades e colaboração no desenvolvimento de nossa vida profissional, e pela profunda visão das questões técnico-científicas.

Ao amigo e ex colega de trabalho, Eng. Agr. Alonso Keese Dodson, incentivador pertinaz do início de nossa qualificação profissional, com o sentimento de ter realizado com este trabalho, parte daquilo que um dia the furtaram. 
À ESALQ/USP, notadamente ao Departamento de Agricultura, pela acolhida em tantos anos de convivio, e pela condição proporcionada à toda a nossa formação profissional.

Ao Prof. Dr. Antonio Luiz Fancelli, nosso orientador, pelo exemplo de profissionalismo e desprendimento pessoal na sua atuação junto à ESALQ/USP, e por possibilitar o desenvolvimento dos nossos objetivos de pesquisa, acreditando que poderiamos cumprir os encargos acadêmicos.

Aos Técnicos- Agricolas José Ciofi, Luiz Carlos Dizeró, Antonio Paulo Mazon Marchetti e Nobuyoshi Ojima, da equipe de Melhoramento do IAA/PLANALSUCAR- COSUL, o reconhecimento pela colaboração na condução do trabalho de campo.

À Bibliotecária Ana Maria Zaia Gheller, pela orientação na revisão de literatura e referenciação bibliográfica.

À Prof. Dra. Marineide Mendonça Aguillera, pelas colaborações e incentivo na elaboração descritiva deste trabalho de tese.

À colaboradora Sonia A. Fachini, pela competência, e pela dedicação na elaboração de mais um trabalho técnico.

À Prof. Sonia M. S. Piedade, do Departamento de Matemática e Estatística da ESALQ/USP, pelas análises e interpretações dos dados produzidos.

Aos companheiros, Eng. Agr. Antonio Augusto Franco Garcia,e Mat. Gustavo Henrique Rosalén dos Santos, pelas colaborações e sugestões na discussão deste trabalho. 


\section{INNICE}

Página

LISTA DE TABELAS ............................................................. i

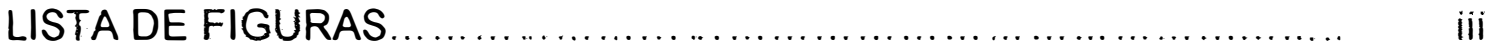

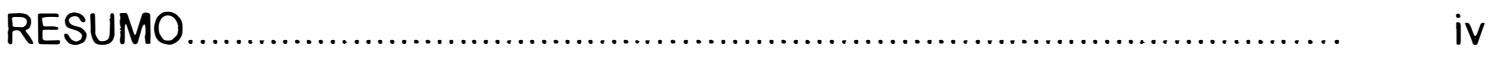

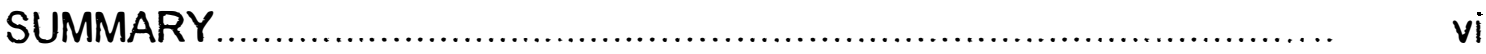

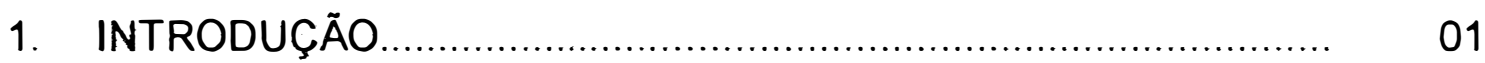

2. REVISÃO DE LITERATURA ................................................. 04

2.1. Controle da podridão-abacaxi ...................................... 07

2.2. Influência do comprimento dos toletes no plantio da canade-açúcar.............................................. 09

2.3. Critérios para o estudo das relações entre doenças de plantas e suas respectivas perdas.

2.4. Terminologia aplicada à caracterização da ocorrência de doenças em plantas

2.5. Metodologias para a avaliação das relacões doençasperdas em plantas............................................

2.6. Modelos para estimar perdas de produção agrícola causadas por doenças......................................

2.7. Avaliação de modelos para estimar perdas por doenças de plantas...................................................... 29

2.8. Teste de modelos de perdas de produção 33 agricola.

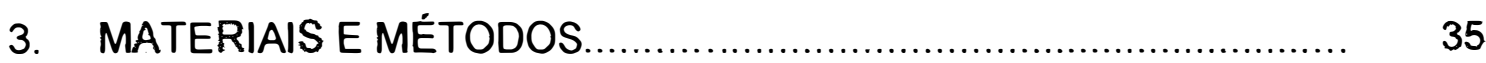

3.1. Local................................................................ $\quad 35$

3.2. Época de plantio....................................................... 36

3.3. Variedades de cana-de-açúcar selecionadas..................... 36

3.4. Indução de diferentes niveis de intensidade de $C$. paradoxa.............................................................. 36

3.5. Delineamento experimental...................................... 37

3.6. Tamanho das sub-parcelas...................................... 38

3.7. Parâmetros avaliados .............................................. 38 
4. RESULTADOS E DISCUSSÃO ............................................ 40

4.1. Avaliação da intensidade de ocorrência de podridãoabacaxi....................................................................... 40

4.2. Brotação inicial aos 50 dias do plantio................................ 45

4.3. Número de perfilhos aos 100, 200 e 310 dias após o

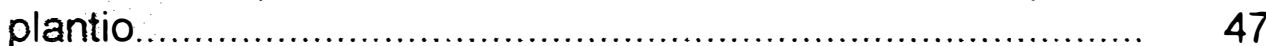

4.4. Número de falhas de plantio........................................... 49

4.5. Comprimento total das falhas de plantio............................. 52

4.6. Número de colmos industrializáveis.................................. 56

4.7. Rendimento agrícola ................................................... 58

4:8. Ajuste de dados para exprimir as relaçōes de intensidade (\%) de ocorrência de podridão-abacaxi com o rendimento agrícola e as perdas de produção agrícola da cana-deaçúcar

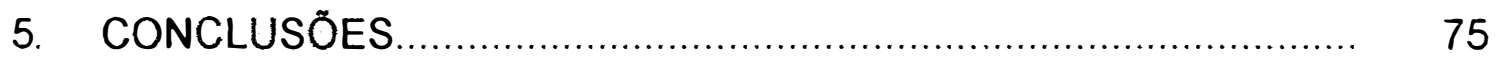

\section{REFERÊNCIAS BIBLIOGRÁFICAS}

\section{APÊNDICES}




\section{LISTA DE TABELAS}

Tabela 1 - Intensidade (\%) de podridão-abacaxi - Frequência (\%) de notas observadas no ensaio de campo e número de toletes examinados em cada parcela experimental .

Tabela 2 - Frequência (\%) de notas e intensidade (\%) de ocorrência de podridão-abacaxi observada por variedade, e intensidade média geral (\%) aos 70 dias após o plantio.

Tabela 3 - Brotação inicial aos 50 dias após o plantio ( número de brotos por 50 metros lineares de sulco ).

Tabela 4 - Número de perfilhos observados aos 110,200 e 310 dias após o plantio ( número de perfilhos por 50 metros lineares de sulco ).

Tabela 5 - Número de falhas entre touceiras formadas, em 50 metros lineares de sulco, nas classes de $50-80 \mathrm{~cm}, 81-120 \mathrm{~cm}$ e maiores que $120 \mathrm{~cm}$, em cana-planta ( dados transformados para $\sqrt{x+1}$, exceto para número total de falhas ).

Tabela 6 - Comprimento das falhas maiores que $50 \mathrm{~cm}$ entre touceiras formadas, nas classes de $50-80 \mathrm{~cm}, 81-120 \mathrm{~cm}$ e maiores que $120 \mathrm{~cm}$, em cana-planta (dados transformados para $\sqrt{x+1}$, exceto para comprimento total de falhas .

Tabela 7 - Ocorrência porcentual de falhas ( $F \%$ ) superiores a $50 \mathrm{~cm}$, e classificação segundo STOLF ( 1986 ).

Tabela 8 - Número de colmos industrializáveis ( número de colmos por 50 metros lineares de sulco ) em cana-planta e cana-soca .

Tabela 9 - Rendimento agrícola ( peso médio das parcelas - kg. ) em cana-planta e cana-soca .

Tabela 10 - Rendimento agricola em toneladas por hectare (t/ha ) em cana-planta e cana-soca . 
Tabela 11 - Rendimento agricola ( $t /$ ha ), perdas ( tha ) e intensidade (\%) de podridão-abacaxi aos 70 dias do plantio (INT \%), obtidos em canaplanta e cana-soca para as variedades NA56-79, RB725828 e RB735275 .

Tabela 12 - Estudo de regressão para a correspondência dos dados de rendimento agricola ( $\mathrm{t} / \mathrm{ha}$ ) e intensidade ( $\%$ ) de podridão-abacaxi aos 70 dias do plantio .

Tabela 13 - Rendimento agricola ( tha ), perdas (t/ha ) e intensidade (\%) de podridão-abacaxi aos 70 dias do plantio ( INT \% ), obtidos para canaplanta e cana-soca .

Tabela 14 - Equações de regressão para os dados conjuntos de rendimento agricola ( $t /$ ha ) das variedades utilizadas, em cana-planta e canasoca, e as respectivas intensidades ( $\%$ ) de podridão-abacaxi aos 70 dias do plantio. 


\section{LISTA DE FIGURAS}

Figura 1 - Avaliação de perdas por podridão-abacaxi em cana-planta.

Figura 2 - Avaliação de perdas por podridão-abacaxi em cana-soca.

Figura 3 - Teste do modelo de previsão de perdas por podridão-abacaxi em cana-planta.

Figura 4 - Teste do modelo de previsão de perdas por podridão-abacaxi em cana-soca. 


\title{
TÉCNICA CULTURAL PARA O CONTROLE DA PODRIDÃO- ABACAXI EM CANA-DE AÇÚCAR E MODELO PARA ESTIMATIVA DE PERDAS
}

\author{
Autor: ENG ${ }^{\circ}$ AGR ${ }^{\circ}$ ANTONIO CARLOS A. GHELLER \\ Orientador: PROF. DR. ANTONIO LUIZ FANCELLI
}

\section{RESUMO}

O estudo quantitativo das perdas provocadas por $C$. paradoxa, agente causal da podridão-abacaxi em cana-de-açúcar, e a sua expressão através de modelo empírico para estimar sua influência na produção agrícola, foram os objetivos básicos deste trabalho. Como decorrência do seu planejamento e como metodologia de desenvolvimento do modelo, foram analisados diferentes métodos de plantio da cana-de-açúcar, como técnica cultural para o controle da doença.

Foram aplicados na instalação do ensaio de campo, cinco tratamentos :a) cana seccionada em toletes de 3 gemas; b) cana seccionada em toletes de 3 gemas com aplicação do fungicida Benomyl (Benlate), na concentração de $0,7 \mathrm{~g}$ do p. c. por litro d'água, através de imersão; c) cana seccionada em toletes de 6 gemas; d) cana seccionada apenas em seu terço superior; e) cana inteira.

O delineamento experimental foi o de blocos casualizados com parcelas subdivididas, com 4 repetições (blocos), nos quais foram distribuidas as variedades NA56-79, RB725828 e RB735275 ( parcelas ), e os tratamentos ( sub-parcelas ). O ensaio foi instalado em solo Latossolo Roxo distrófico, na Estação Experimental de Cana-de Açúcar de Araras/SP, antes pertencente ao IAA/PLANALSUCAR, e atualmente sede do Centro de Ciências Agrárias da Universidade Federal de São Carlos-CCA/UFSCar. 
A medida da intensidade (\%) de podridão-abacaxi, efetuada aos 70 dias após a instalação do ensaio, representando a severidade da infecção do fungo $C$. paradoxa nos tecidos dos colmos plantados, foi sistematizada através da escala de notas : 1-início ou ausência de infecção; 2infecção em $1 / 3$ da extensão do tolete; 3 -infecção superior a 1/2 do tolete, e 4infecção em toda a extensão do tolete.

A análise dos dados obtidos permitiu concluir que a podridão-abacaxi, em condições de clima favoráveis à sua ocorrência, infecciona severamente os toletes de cana-de-açúcar plantados, caso tenham sido seccionados à maneira convencional (3 gemas), diminuindo sua intensidade (\%) de infecção à medida que se aumenta o tamanho do tolete plantado, de valores próximos a $100 \%$ (toletes de 3 gemas) para valores ao redor de $38 \%$ (cana plantada inteira). O efeito da doença foi maior na canaplanta, e os maiores rendimentos agrícolas ocorreram nos tratamentos com menor número de seccionamentos dos colmos plantados. Demonstrou-se que adequado controle da podridão-abacaxi em cana-de-açúcar, se obtém com a utilização de toletes de 12 a 18 gemas, isto é, procedendo-se a apenas um seccionamento, ou nenhum, em colmos de no máximo 12 meses de idade, o que proporcionou, além de ganhos no rendimento agrícola ( $t / h a)$, melhor qualidade de plantio, comparado ao sistema tradicional.

A avaliação da redução da produção agrícola em relação à intensidade (\%) de podridão-abacaxi, pode ser estimada pela aplicação do modelo empírico de regressão considerando um ponto crítico na ocorrência da podridão-abacaxi, aos 70 dias do plantio, resultando na relação representada pela equação $y=0,46(x-44,59)$, com coeficiente de determinação $r 2=0,837$, onde " $y$ " é a redução da produção de cana-de açúcar em toneladas por hectare e " $x$ " a intensidade (\%) da doença, equação válida para valores de intensidade (\%) acima de $44,59 \%$. 


\title{
CULTURAL TECHNIQUE FOR CONTROLLING PINEAPPLE DISEASE ON SUGARCANE AND MODEL FOR ESTIMATING LOSSES
}

\author{
Author: ENG ${ }^{\circ}$ AGR ${ }^{\circ}$ ANTONIO CARLOS A. GHELLER \\ Adviser: PROF. DR. ANTONIO LUIZ FANCELLI
}

\section{SUMMARY}

The assessment of losses caused by Ceratocystis paradoxa, the causal agent of pineapple disease on sugarcane, as well as its expression through an empiric model for estimating the effects on yield were the main objectives of this research. As a consequence of the processes of planning and determining the methodology on which the model was established, different systems of sugarcane planting aiming at to control that disease were analysed.

A field experiment was set with five treatments: a) stalk cut into 3-bud seedpieces; b) stalk cut into 3-bud seedpieces plus Benlate (Benomyl) application at the concentration of $0.7 \mathrm{~g}$ of the commercial product per liter of water by immersion; c) stalk cut into 6-bud seedpieces; d) stalk cut at its upper third; e) whole stalk.

The experimental design consisted of randomized blocks with sub-plots and four replications (blocks) in which the varieties NA56-79, RB725828, and RB735275 (plots) and five treatments were analised. The experiment was set in a dystrophic Dusk-Red Latosol at the Estação Experimental de Cana-de-Açúcar located in Araras, SP, formerly belonging to IAAJPLANALSUCAR and presently housing the Centro de Ciências Agrárias, Universidade Federal de São Carlos -- CCAUUFSCar. 
Pineapple disease incidence was evaluated 70 days after the experiment was set, and represents infection severity of the fungus $C$. paradoxa on the planted seedpieces tissues. Pineapple disease infection was arranged according to the following grade system: 1 - initial or no infection; $2-1 / 3$ seedpiece lenght infected; 3 - more than $1 / 2$ seedpiece infected; 4 - whole seedpiece infected.

Data analyses allowed to conclude that pineapple disease, under favorable conditions to its incidence, can severely affect planted sugarcane seedpieces, if these are cut into 3-bud cuttings as usual. Disease intensity decreases as the seedpiece lenght is increased, from about $100 \%$ in 3-bud seedpieces to circa $38 \%$ in whole stalk. Yield was more affected in plant cane and was higher in those treatments in which a smaller number of cuts was done. It can be concluded that proper control of pineapple disease is obtained by planting 12-18-bud seedpieces. This means that one or even no cutting should be executed in the stalk if the cane is no older than 12 months. This practice allows best planting quality and increases in yield, as compared to traditional planting system.

Evaluation of yield losses as related to pineapple disease intensity (\%) can be estimated by applying the empirical model of regression considering incidence of the disease at 70 days after planting as the critical point, thus resulting in the equation $y=0.46(x-44.59)$, with a coefficient of determination $r^{2}=0.837$, where " $y$ " represents sugarcane yield decrease in tons per hectare and " $x$ " the disease intensity. This equation can be used for intensity (\%) values above $44.59 \%$. 


\section{INTRODUÇÃO}

A cultura da cana-de-açúcar assumiu, nestas duas décadas finais do século $X X$, importância econômica e estratégica para ○ Brasil, superior àquela que já representou nos tempos do Brasil colônia. De fato, a significativa participação de seus produtos e sub-produtos na economia brasileira, notadamente o açúcar tradicional e o álcool como integrante definitivo da matriz energética nacional, ao lado da crescente alcoolquímica, vem acompanhada de abertura de novas frentes de desenvolvimento tecnológico tanto para a indústria como para a agricultura.

No setor agricola, a cultura de cana-de-açúcar é participante ativa da economia de todos os Estados brasileiros, estendendo-se por área superior a 4 milhões de hectares. No Estado de São Paulo concentra-se cerca de $42 \%$ da cultura, respondendo por $56 \%$ do açúcar e $68 \%$ do álcool produzidos em cada safra canavieira do Brasil. Para isso, somente em São Paulo, são plantados anualmente algo ao redor de 250.000 hectares de novos canaviais, apenas em regime de renovação, cujas produtividades e longevidades dependerão da implantação adequada destes canaviais, um dos pontos críticos para o sucesso desta cultura como de qualquer outra.

Plantada normalmente de setembro/outubro até março/abril no Centro-Sul brasileiro, e por vezes adentrando até nos meses do final do outono 
e todo o inverno em algumas regiões onde existam condições minimas de temperatura e umidade para isso, a cana-de-açúcar fica sujeita a situações delicadas e até críticas para desenvolver sua brotação inicial e consequente formação das futuras touceiras, que serão exploradas intensivamente por quatro até seis ou mais cortes sucessivos. Nesta fase é comum a ocorrência de podridão nos toletes com reflexos imediatos na formação da lavoura. Dentre as podridões que ocorrem nos toletes de cana-de-açúcar recém plantados, destaca-se a podridão-abacaxi, conhecida em todo o mundo canavieiro sob esta designação, como também é relatado ocorrendo onde outras plantas hospedeiras são cultivadas (TOKESHI, 1980; WISMER, 1961).

A Podridão Abacaxi dos toletes, é doença cuja ocorrência remonta ao final do século passado, quando foi descrita ocorrendo na cana-deaçúcar, e é causada pelo fungo Ceratocystis paradoxa (Dade) Moreau. É importante doença nas regiōes tropicais, sendo particularmente mais prejudicial em plantios realizados em épocas de temperatura amena e solo com baixa ou excessiva umidade, condições que restringem a brotação inicial rápida das gemas dos toletes da cana-de-açúcar.

Pelo fato de ser polifago, o fungo $C$. paradoxa ocorre em todas as regiōes onde a cana-de-açúcar é cultivada, sendo sua importância econômica variável conforme as condiçōes de umidade do solo, temperatura e velocidade de brotação dos toletes. As irregularidades climáticas das regiões Nordeste e Leste do Brasil predispõem a ocorrência da doença em larga escala. No Sul do pais, as condições que favorecem a doença aparecem nos meses de março a agosto, quando períodos de seca ou umidade excessiva, associados a temperaturas baixas, e quando o cobrimento dos toletes da canade-açúcar com terra é demasiado, provocam o retardamento da brotação dos toletes (TOKESHI, 1980; HUGHES, 1976).

Relatos de perdas na produção final da cana-de-açúcar causados pela Podridão Abacaxi são bastante expressivos. TOKESHI (1980) 
referiu-se a alguns casos onde foi observado queda superior a $30 \%$, devido a deficiências na brotação inicial dos toletes. WISMER \& BAILEY (1989) relatam que perdas economicamente significativas são registradas na Austrália, Brasil, Havai, Mauritius, África do Sul e Taiwan, embora não quantificadas.

A situação endêmica do fungo $C$. paradoxa pressupõe uma potencial fonte de prejuizos à cultura canavieira, embora sua ocorrência seja economicamente importante somente em determinadas situações edafoclimáticas. O controle preventivo com produtos químicos não é prática usual, o que permite a ocorrência de surtos epidêmicos, cuja conseqüência maior é referida como perdas devido à doença. Em muitas outras situações, as falhas na formação do canavial são atribuidas às más condições de brotação inicial, não se determinando as causas especificas, uma das quais, geralmente, é a podridão-abacaxi. Porém, a avaliação crescente da incidência do fungo,é registrada na literatura apenas em conclusões preliminares de MATSUOKA \& GHELLER (1984), não havendo, porém, conhecimento da interação relativa de niveis de incidência de $C$. paradoxa e perdas associadas, numa forma modelar que permita a extrapolação futura de possiveis perdas numa determinada incidência da doença. Este é o objetivo básico deste trabalho que propõe uma metodologia de avaliação de perdas causadas pela podridão-abacaxi dos toletes em cana-de-açúcar e o estabelecimento de um modelo de interpetação e aplicação prática dos niveis de incidência da doença no campo.

Também, como suporte metodológico à investigação proposta e busca de métodos de plantio de cana-de-açúcar que permitam algum controle sobre a incidência de podridão-abacaxi, foram avaliadas hipóteses de aplicarse um processo cultural de defesa contra a infecção por $C$. paradoxa, através da utilização de diferentes tamanhos de toletes de cana-de-açúcar na implantação de novas lavouras. 


\section{REVISÃO DE LITERATURA}

A podridão-abacaxi em cana-de-açúcar é essencialmente uma doença relacionada ao solo e aos toletes utilizados na formação inicial da lavoura, sendo encontrada onde quer que a cana-de-açúcar seja cultivada. Seu agente causal, segundo WISMER \& BAILEY (1989) é um fungo cuja forma perfeita é denominada Ceratocystis paradoxa (Dade) Moreau; a forma imperfeita, denominada Thielaviopsis paradoxa (de Seynes) V. Hohn, é a que aparece atacando a cana-de-açúcar (McMARTIN, 1944), sendo o estágio conidial do fungo, cuja esporulação é intensa na presença de $\mathrm{O}_{2}$. HUGHES (1976) admitiu que o agente causal $C$. paradoxa cresce facilmente na matéria orgânica do solo e produz abundância de esporos de longa sobrevivência. Sua transmissão é usualmente a partir do solo para os toletes, mas às vezes colmos em pé podem ser infectados por esporos levados pelo vento, entrando pelos ferimentos ou por infecção vindo dos restolhos (rizomas).

Condições específicas de temperatura e umidade do solo após o plantio são os fatores que condicionam as infecções severas de C. paradoxa. Para brotação satisfatória das gemas, temperatura do solo acima de $21^{\circ} \mathrm{C}$ é requerida, sendo ótimo os valores entre 33 e $37^{\circ} \mathrm{C}$, existindo resposta diferencial das variedades de cana-de-açúcar à temperatura de brotação inicial 
(Clements', citado por BURR et al. (1957); CAMARGO, (1970). De modo geral, pode ser afirmado que a temperatura abaixo de $21^{\circ} \mathrm{C}$ o desenvolvimento das gemas é bastante lento e acima de $21^{\circ} \mathrm{C}$ aumenta progressivamente até um ótimo entre 31 e $36^{\circ} \mathrm{C}$ (VAN DILLEWIJN, 1948).

A sensibilidade dos toletes de cana à temperatura é ilustrado pelo fato de que a queda da temperatura do solo de $25,5^{\circ} \mathrm{C}$ para $22^{\circ} \mathrm{C}$, adiciona dez dias no tempo de brotação inicial das gemas na variedade H32-8560, segundo Das ${ }^{2}$, referido em BURR et al. (1957).

Toletes sadios de cana-de-açúcar postos a brotar em condições normais de solo produzirão rapidamente raizes e brotações das gemas, estabelecendo satisfatória população de perfilhos. Entretanto, se o solo está muito frio, ou muito úmido, ou seco, ou a cobertura de terra dos toletes está espessa demais, a brotação das gemas é lenta, o que proporcionará tempo para o fungo se estabelecer e impedir o desenvolvimento de outras brotações, de acordo com afirmaçōes de HUGHES (1976). BOYD \& GALLI (1966) verificaram que o fungo causador da podridão-abacaxi somente começa a exercer influência nas gemas que brotam depois de 16 dias, e que 15 dias em condições normais é o período necessário para a brotação inicial das gemas. BOYD \& ALLISON (1968) definiram que a brotaçảo inicial da cana é uma corrida contra o tempo entre a gema em crescimento e o patógeno invasor, e embora o fungo seja capaz de matar a gema, esta tem pequena ou nenhum efeito direto no desenvolvimento do fungo.

TOKESHI (1980) observou canaviais em área superior a 50 hectares totalmente perdidos após três plantios sucessivos devido à presença intensa de $C$. paradoxa no solo. Este mesmo autor considerou ser o retardamento da brotação das gemas como o fator mais importante para o

\footnotetext{
${ }^{1}$ CLEMENTS, H.F. Factors affecting the germination of sugar cane. Hawaiian Planter's Record, Honolulu, 44:117-146, 1940.

2 DAS, V.K. Hawaiian Planter's Record, Honolulu, 40:103-104, 1935.
} 
aparecimento da doença, cujas causas são definidas como solo seco ou encharcado, falta de oxigênio, gemas velhas, enterrio em demasia dos toletes, e temperaturas abaixo de $20^{\circ} \mathrm{C}$.

Note-se que as condições citadas por HUGHES (1978) e TOKESHI (1980), são facilmente encontradas em diversas regiões canavieiras do Nordeste e Leste brasileiros, assim como nos plantios tardios das regiões Sul e Sudeste do País, notadamente quando a cana-de-açúcar é explorada em rotação com outras culturas, o que impõe um certo atraso nas operações de plantio das novas lavouras. SORDI (1983a) considerou que existem casos em que todo o plantio de cana-de-açúcar necessita ser refeito devido ao exagero das falhas existentes e causadas pela podridão-abacaxi. Quando a brotação inicial é prejudicada, fatalmente irão ocorrer prejuizos em todos os cortes do canavial, fato não devidamente mensurado. Acrescentou que tal prejuizo não se resume apenas às falhas de plantio, mas também no desenvolvimento das plantas, devido a toxinas produzidas pelo fungo, fato este que pode se manifestar inclusive nas soqueiras. Considerou grandes os danos de brotação inicial observado nas variedades NA56-79 e RB725828. WISMER \& BAILEY (1989) admitiram que sob condições que favoreçam seu desenvolvimento, a Podridão Abacaxi causa substancial perda de produção em cana-de-açúcar, através das falhas na brotação das gemas e a partir da morte dos brotos novos de toletes atacados. C. paradoxa apresenta inibição na emissão de raizes dos toletes infectados, e isto é devido a componentes voláteis produzidos pelo fungo (Byther $\&$ Moore, 1974$)^{3}$. Além das perdas diretas pelo efeito danoso na população de perfilhos, a Podridão Abacaxi pode exigir replantios na área afetada e aumentar os custos de controle de plantas daninhas pelo atraso imposto ao desenvolvimento das plantas.

\footnotetext{
${ }^{3}$ BYTHER, R.S. \& MOORE, P.H. Inhibition of sugarcane rooting by C. paradoxa. Canadian Journal of Botany, 52:761-766, 1974.
} 
A inibição da brotação inicial dos toletes de cana-de-açúcar é causada, segundo BYTHER \& STEINER (1970), pelo acetato etilico produzido por $C$. paradoxa. Altos niveis deste composto inibiu o enraizamento e quando isto ocorreu, foi detectado a presença de etileno. Foi proposto que um componente volátil produzido pelo patógeno estimula a planta a produzir etileno, o qual inibe o enraizamento, que seria um possivel fator de redução da brotação inicial e vigor dos toletes infectados por C. paradoxa. Também KUO et al. (1969) identificaram o acetato etílico como substância fitotóxica capaz de inibir a brotação das gemas da cana-de-açúcar.

O fungo C. paradoxa é incapaz de penetrar por seus próprios meios em tecidos integros ou através das aberturas naturais da planta de canade-açúcar, o que não ocorre nos toletes utilizados no plantio, os quais são seccionados transversalmente com o intuito de se evitar a dominância apical entre as gemas do colmo e favorecer a brotação da maior parte delas. É de longo tempo conhecido que tais seccionamentos constituem as portas de entrada para o fungo (WISMER,1961 e TOKESHI, 1980). Observações recentes têm mostrado que o uso de colhedoras mecânicas de cana picada para abastecimento das plantadoras mecânicas de cana-de-açúcar, tem provocado, em plantios atrasados no Estado de São Paulo, maiores incidências de podridão-abacaxi, quando comparado ao plantio e corte manual das mudas, provavelmente devido à maior danificação dos toletes com abertura de novas portas de entrada para o fungo causador da doença.

\subsection{Controle da podridão-abacaxi}

HUGHES (1978) citou ser o controle de C. paradoxa efetivo, prático e de menor custo, quando comparado a outros custos das operações de plantio da cana-de-açúcar. Este controle feito através da aplicação de 
fungicida diretamente nos toletes destinados ao plantio, deve ser prática rotineira em regiões onde a ocorrência do fungo é epidêmica.

Trabalhos conduzidos no Havai por HILTON et al. (1971) recomendaram o uso do Benlate (Benomyl) para o controle químico de C. paradoxa, na dosagem de 0,6 g/litro, em tratamento por água fria e 0,3 g/litro em conjunto com o tratamento térmico curto $\left(50 / 52^{\circ} \mathrm{C}\right.$ por $30 / 20$ minutos) ou longo $\left(50 / 51^{\circ} \mathrm{C}\right.$ por 2 horas).

No Brasil testou-se 18 fungicidas em substituição aos produtos mercuriais disponiveis até então, destacando-se a eficiência dos fungicidas conhecidos comercialmente como Benlate, Captam 50 e Cycosin. O uso do Benlate nas concentrações de $65 \mathrm{~g}$ e $35 \mathrm{~g}$ por 100 litros de água para tratamento a frio e a quente, respectivamente, foi recomendado para o controle da podridão-abacaxi da cana-de-açúcar, como sendo o mais eficiente dos fungicidas testados (IAA/PLANALSUCAR, 1972 e 1974), que passou a ser recomendação para todo o Brasil (IAAMPLANALSUCAR; 1975). SORDI (1983b) testando dois fungicidas para controle da podridão-abacaxi na variedade NA56-79, concluiu pela maior eficiência do Benlate.

WISMER(1961) e WISMER \& BAILEY (1989) consideraram que a podridão-abacaxi é controlada evitando-se as condições que favoreçam o desenvolvimento da doença, e pelo uso protetor de fungicidas. Os toletes jovens favorecem rápida brotação, e uma vez que a podridão evolui das extremidades em direção ao centro dos toletes, e é temporariamente mais lenta nos nós, o uso de toletes com ao menos três nós (gemas) aumenta a probabilidade de brotação das gemas da parte central.

Comentários de VAN DILLEWIJN (1952) abordam as influências do tamanho do tolete na brotação das gemas e relataram o uso de toletes com uma, duas ou no máximo três gemas para plantios realizados comumente em diversos paises; entretanto, independente de associação com podridões dos toletes, considerou que em condições de plantio menos 
favoráveis, o comprimento dos toletes deve ser adequadamente aumentado, destacando que sob condições severas de crescimento é preferível plantar toletes de cana-de-açúcar com 4 e 6 gemas que de menores comprimentos.

Este comentário distante de VAN DILLEWIJN (1952) foi reativado, ao menos no Brasil, no final da década dos anos 80 , quando se passou a discutir a diminuição do seccionamento dos colmos de cana plantados, de maneira bastante drástica, com os estudos de plantio de colmos inteiros, objetivando diminuir os custos da mão-de-obra desta operação (LEE, 1984; LEE et al., 1986 e BRITO, 1988). Com isso, aventou-se a hipótese, então não avaliada, de que se estava reduzindo as portas de entrada do fungo causador da podridão-abacaxi (MATSUOKA \& GHELLER, 1984) e que isso provavelmente surtiria efeito na produção da cultura, independente de qualquer efeito aditivo ou não provocado pelo tamanho do tolete posto a brotar. Também, e obviamente, permitiu considerar que o seccionamento do colmo para plantio em dimensões intermediárias entre 3 gemas e cana inteira poderia ter vantagens e evitaria dificuldades no manuseio do colmo inteiro, fundamentando a proposta de técnica cultural de controle da podridão-abacaxi ora em avaliação.

\subsection{Influência do comprimento dos toletes no plantio da cana-de- açúcar}

O seccionamento dos colmos em toletes de 3 gemas foi recomendação e aplicação tradicional no Brasil,como também em todo o mundo canavieiro, fundamentado no efeito da dominância apical existente entre as gemas distribuídas ao longo do colmo da cana. VAN DILLEWIJN (1952) abordou em seu tratado "The Botany of Sugar Cane", as questões da brotação inicial nos toletes, citando que quando se planta toletes de mais de 
uma gema, entra em jogo um fator adicional na forma da dominância apical. Tal fator é ativo nos colmos inteiros e em qualquer secção de colmo com mais de uma gema, casos em que a gema apical mais jovem brotará rapidamente e ao mesmo tempo retardará, e até inibirá, o desenvolvimento das gemas inferiores, dando como resultado uma \% de brotação média menor quando comparado com toletes mais curtos.

ARCENEAUX (1948) em ensaios conduzidos na Louisiana (USA), comprovou que toletes de 5 gemas são os que melhores rendimentos de produção proporcionam no plantio de outono. Estas afirmações foram confirmadas por CHOW (1949) em Formosa, onde observou que em caso de severas condições de crescimento, toletes de 4 a 6 gemas são preferiveis àqueles mais curtos.

Ainda VAN DILLEWIJN (1952) comentou ser o comprimento mínimo dos toletes determinado principalmente pela qualidade da muda e pelas condições de crescimento. Em Java onde tais fatores são favoráveis, utiliza-se toletes com duas ou apenas uma gema desenvolvida. Em regiões com condiçōes menos favoráveis, o comprimento dos toletes tem que ser aumentado adequadamente, como nos plantios de outono nas regiões temperadas, onde as condiçōes de brotação são ruins.

Clements $^{4}$, citado por HUMBERT (1974) concluiu que toletes de mais de três gemas são um desperdício de gemas extras. Toletes de três gemas são usados no Hawai e em muitos outros paises. Toletes de uma só gema brotam, porém, o desenvolvimento da planta é reduzido, com diâmetro dos brotos menor comparado aos do tolete de três gemas.

LONDSDALE (1977) em trabalho conduzido na Rodésia, concluiu que, quanto ao número de falhas no plantio, existiu vantagens para o uso de toletes de três gemas, se eles fossem mergulhados antes do plantio em

4 CLEMENTS, H.F. Factors affecting the germination of sugar cane. Hawaiian Planter's Record, Honolulu, 44:117-146, 1940. 
solução de fungicida e inseticida. Plantio com toletes de 3 gemas tratadas foi superior aos tratamentos com 1, 5 ou 7 gemas em relação a falhas de plantio, resultando numa emergência mais uniforme. Entretanto, para a produção em toneladas de cana por hectare, não houve diferenças significativas entre plantio em toletes de 3 gemas (tratadas com fungicida e inseticida ou não), toletes de 5 a 7 gemas e mesmo cana inteira seccionada no sulco, cana inteira sem seccionamentos e com e sem palha. Este fato indica a habilidade da cana-de-açúcar em compensar falhas existintes no plantio.

KANWAR et al. (1975) considerou que toletes com 2, 3, 4 e 5 gemas proporcionaram melhor brotação e perfilhamento que toletes de 6 gemas, e canas inteiras. Não houve, entretanto, diferenças significativas na produção de colmos por hectare e na população dos colmos entre os tratamentos citados. Para o plantio de colmos inteiros, observou-se menores rendimentos por área, tanto em cana planta como cana soca.

Nota-se que a grande tendência na conclusão dos trabalhos sobre a brotação inicial da cana-de-açúcar, é considerar-se preferível o seccionamento do colmo em toletes não maiores que 3 gemas. Algumas informaçōes, entretanto, sinalizavam para a oportunidade de utilizar-se toletes maiores (LONDSDALE, 1977; CHOW, 1949; ARCENEAUX, 1948; VAN DILLEWIJN, 1952). LONDSDALE (1977) também considerou que agricultores rodesianos, num esforço de economizar mão-de-obra, plantaram canas em colmos inteiros, obtendo boas brotaçōes iniciais.

YANG et al. (1981) não encontraram diferença significativa no número de colmos e comprimentos dos colmos, entre plantas crescidas a partir de plantio de canas inteiras e em toletes de duas gemas.

MA (1980) sugeriu que o uso de colmos inteiros ao invés de toletes com duas gemas, tem as seguintes vantagens:

- economia de mão-de-obra; 
- redução da deficiente "germinação" induzida por alta precipitação e alto nivel de umidade no solo;

- perfilhamento precoce com benefício para o crescimento da planta em estágio posterior;

- aumento no número de colmos industrializáveis;

- redução dos custos de plantio.

Entretanto, cuidados devem ser atendidos para a qualidade das mudas, tais como:

- controle fitossanitário;

- é mais aplicável para canas eretas e com 8-10 meses ou 10-12 gemas por colmo.

Em experimentação no Estado de São Paulo, LEE (1984) avaliou o sistema de plantio convencional (toletes de 3 gemas), comparando-o ao plantio com cana inteira com e sem pontas e com e sem palha, realizado no mês de setembro. Concluiu serem os rendimentos de cana e açúcar semelhantes nos dois métodos de plantio estudados, e que não houve influência na qualidade tecnológica da cana produzida a partir de plantio de canas inteiras. A \% de falhas foi maior nos plantios de cana inteira (plantadas na razão de 12 gemas por metro linear), porém sem afetar o rendimento final observado, situando-se tais falhas entre $8-9,6 \%$ para canas inteiras contra $3,4 \%$ para o tratamento convencional de 3 gemas. Mesmo assim, esse indice de falhas inferior a $10 \%$ (das falhas maiores que $50 \mathrm{~cm}$ ) é classificado por STOLF (1983) como de excelente qualidade de plantio.

A avaliação das falhas no plantio e sua relação com a produção final da cana-de-açúcar foi analisada por STOLF $(1983 ; 1986)$ e STOLF et al. (1986 e 1991) em cana planta e socas, propondo-se a avaliação da qualidade do plantio em relação às falhas da seguinte forma: 


\begin{tabular}{cc}
\hline$\%$ Falha $>0,5 m$ & Avaliação do Plantio \\
\hline $0-10$ & Excelente $^{\star}$ \\
$11-20$ & Bom $^{\star \star}$ \\
$21-35$ & Médio \\
$36-50$ & Ruim \\
$>50$ & Péssimo
\end{tabular}

(*) Para 15 gemas por metro linear e condiçōes excepcionais de brotação

$\left.{ }^{\star \star *}\right)$ Normal - tipo mais encontrado

Noutro grupo de experimentos conduzidos em diversas localidades do Estado de São Paulo, LEE et al. (1986) confrontaram o plantio convencional de cana picada e com o plantio de canas inteiras e recomendaram o seguinte procedimento para a utilização da cana inteira no plantio:

- utilizar mudas com 8-10 meses de idade para cana planta, e no máximo 9 meses caso utilizar-se de cana soca;

- não descartar o palmito da muda, mantendo-se todas as bainhas das folhas do palmito, para evitar-se o levantamento de pontas;

- plantar as canas com pé e ponta bem cruzados;

- evitar a cobertura da cana com muita terra, sendo $5 \mathrm{~cm}$ a quantidade ideal;

- utilizar variedades que se apresentem eretas quando da coleta de mudas.

BRITO (1988) estudando o plantio convencional (3-4 gemas/tolete) com os sistemas de meia cana com e sem desponte e cana inteira com e sem desponte, nas variedades NA56-79 e CB45-3 em plantio feito em março, concluiu que não foram afetados o rendimento agrícola e as características tecnológicas da cana-de-açúcar, nos sistemas analisados. 
Também, observou que houve diferenças significativas para os parâmetros número de colmos colhidos por hectare, peso médio dos colmos, diâmetro médio dos colmos, arqueamento das mudas e \% de área falhada nos diferentes sistemas de plantio, que entretanto, não influenciaram a produção de canas por área (tha) e açúcar por área (t açúcar/ha). Informou com tais observações, ser possivel sugerir-se a utilização de colmos inteiros no plantio da cana-deaçúcar.

Provavelmente as conclusões de BRITO (1988), tenham sentido se considerarmos a grande capacidade de compensação existente na população dos colmos da cana-de-açúcar, quando, dentro de limites, altera-se a sua distribuição no campo, embora em seu trabalho, apenas o tratamento Cana Inteira com desponte foi inferior e diferente estatisticamente dos demais. Necessário seria conduzir as observações para cortes mais avançados, onde são normais alterações na população de colmos e na sua distribuição, causada principalmente por problemas na colheita e nos cultivos mecânicos.

Segundo o mesmo trabalho de BRITO (1988) a qualidade de plantio foi considerada excelente para o sistema convencional, e média para os sistemas com meia cana e canas inteiras despontadas ou não. Para a análise de $\%$ de falhas, observou-se pela metodologia proposta por STOLF et al. (1986) que houve falhas ao redor de $2,6 \%$ para o sistema convencional contra 20-31\% para os demais sistemas de plantio estudados. Estes dados divergem um pouco daqueles de LEE (1984), que encontrou qualidade excelente de plantio com canas inteiras, porém em plantio de ano, com falhas na ordem de $10 \%$ apenas. Considere-se que em ambos os trabalhos, utilizou-se um número de gemas plantadas por metro linear de sulco inferior aos plantios comerciais (20-25 gemas/metro), o que ajudaria a minimizar o fato.

Quanto ao arqueamento das mudas e consequente levantamento das pontas, BRITO (1988) concluiu não haver diferença significativa entre o sistema convencional (3-4 gemas) e os sistemas de meia 
cana e cana inteira sem desponte. Analisou-se que a presença da gema apical mais o efeito mecânico das folhas deva ter contribuido para reduzir o arqueamento. Para os sistemas de meia cana e cana inteira com desponte, houve diferenças significativas para os demais tratamentos no arqueamento das mudas plantadas. Estas conclusões estão em acordo com as observações de LEE (1984) e ambos autores definiram não ter havido comprometimento dos rendimentos agricolas e industrial pelo fato de ter ocorrido diferentes niveis de arqueamento das mudas.

Observa-se que, apesar do uso intensivo do seccionamento do colmo destinado ao plantio, comprimentos maiores podem ser vantajosos para determinadas épocas de plantio, principalmente quando houver condições predisponentes à ocorrência de C. paradoxa. Prejuizos advindos dos problemas relativos à dominância apical entre as gemas dos toletes de diversos tamanhos não são, atualmente, impedimento à sua utilização prática. A associação deste procedimento, que pode ser, provavelmente, um método cultural de controle da podridão-abacaxi, além de ser um procedimento técnico para avaliaçāo de perdas em diferentes intensidades de doença, é proposta a ser analisada neste trabalho.

\subsection{Critérios para o estudo das relaçōes entre doenças de plantas e suas respectivas perdas}

Basicamente, o problema de avaliação de perdas causadas por doenças em plantas consiste em medir a intensidade da doença e interpretá-la perante as perdas provocadas (CHESTER, 1950).

Durante a década de 1960, passou a haver maior interesse em avaliação de perdas por doenças de plantas, devido à necessidade de 
desenvolvimento de mais sofisticados métodos de administração das doenças que justifiquem e racionalizem o uso de fungicidas (JAMES, 1974).

ZADOKS (1987) considerou a administração de pragas e doenças como um conjunto de disciplinas de biologia e economia; é necessário ao produtor conhecer quando é econômico tratar sua plantação e quando não o é. Entretanto, quando a situação da doença ou praga atinge um grau no qual a necessidade de tratamento venha a ser óbvia, a lavoura pode estar perdida. Esta situação pode ser evitada com a previsão da possivel ocorrência.

Outros autores tem se referido ao problema de quantificar com maior rigor a ocorrência de doenças de plantas e sua relação com as perdas conforme o seu indice de ataque. LARGE (1966) considerou que o principal propósito do trabalho de medida da doença de plantas é melhorar a forma de seus registros, fazendo isso não somente de forma qualitativa, mas também quantitativa. JAMES (1974) afirmou que as doenças de plantas foram inicialmente estudadas devido às perdas que causam, e é paradoxal que ainda existam poucas estimativas confiáveis destas perdas.

A perda ocasionada por doença em plantas deve ser necessariamente quantificada, para que se decida pela adoção de técnica de controle adequada, cuja estratégia pode ser simples, sem altos investimentos, mas com retorno às vezes surpreendente em termos de produção (BERGAMIN $F^{\circ} \&$ AMORIM, 1991).

Qualquer agente biológico que danifique a plantação é chamada "um organismo nocivo". Três conceitos essencialmente diferentes podem ser distinguidos para caracterizar tal situação: Produtividade (yield) é o produto mensurável de valor econômico de uma plantação; Injúria (injury) significa qualquer sintoma visível e mensurável causado por um organismo nocivo, e equivalente ao obsoleto termo "crop damage"; Dano (damage) seria qualquer redução em quantidade elou qualidade da produção, e equivalente ao termo "crop loss"; Perda (loss) seria a redução em retorno financeiro por 
unidade de área devido à ação de organismos nocivos. Injuria pode levar a dano, e consequentemente à perda, posto que os mecanismos de ação nos preços podem interferir. A demanda por produtos agricolas é geralmente "inelástica", com os preços caindo quando o mercado está saturado e subindo caso haja escassez do produto (CHIARAPPA, et al., 1971; ZADOKS, 1987).

Também é de ZADOKS (1987) a conceituação de que a densidade de população de um organismo nocivo pode ser determinada diretamente (presença de insetos por exemplo), ou indiretamente através da avaliação da injúria provocada, como é o exemplo com patógenos foliares. A função dano relaciona dano com injúria $-D=f(I)$, e a função perda relaciona perda com dano $-P=f(D)$. A equação matemática que descreve a "função dano" pode ser estabelecida com razoável precisão para qualquer patossistema, num contexto de um sistema definido de produção. Os parâmetros variarão de acordo com o cultivar, o local, o tipo de solo e muitos outros fatores. A "função perda" é mais difícil de se determinar pois depende da situação financeira do local e da época.

BERGAMIN F' (1995) considerou a existência dos fenômenos de compensação intraplanta e compensação interplanta, quando se estabelece uma produção contrabalanceada à ação de um determinado agente causal; admitiu também a ocorrência de uma produção residual mesmo em campos severamente infestados. Entre os limites da compensação de produção e o limite da produção residual situa-se a faixa de alta correlação injúria-produção, numa analogia direta à relação injúria-dano.

Para o estudo ora proposto onde serão analisadas as interferências de um patógeno na cultura da cana-de-açúcar, e dada às características da comercialização deste produto, altamente estabilizada, e aos fatores agroclimatológicos variáveis conforme as regiōes e épocas do ano, permitindo equilibrio de produção global, permite-se que a relação injúria-dano seja diretamente relacionada à relação injúria-produção ou injúria-perda. 


\subsection{Terminologia aplicada à caracterização da ocorrência de doenças em plantas}

A diagnose e a avaliação das doenças de plantas são funções importantes de fitopatogistas. Diagnose das doenças mais comuns é baseada na identificação do patógeno e/ou sintomas, usando métodos universalmente conhecidos e aceitos. Por comparação, métodos de avaliação de doenças tem recebido muito menos atenção, e muitos métodos publicados são tão difíceis de aplicar com uniformidade que não são largamente aceitos (JAMES, 1974).

A medida de intensidade da doença de plantas desempenha 0 mesmo papel para o pesquisador que a sua diagnose. Sem quantificação da doença, nenhum estudo em epidemiologia, nenhuma avaliação de perdas de produção e nenhuma inspeção de doença em plantas e suas aplicações, seria possível. A intensidade da doença pode ser expressa como incidência (ou frequência) ou severidade, sendo a incidência representada pela \% de plantas (KRANZ, 1988). Diversos autores tem destacado especial interesse na utilização apropriada da terminologia científica na avaliação de doenças de plantas. Tehon e Stout ${ }^{5}$, citados por CHESTER (1950), distinguiram dois componentes na intensidade de doença, limitando o termo "intensidade" à quantidade de doença em plantas individuais e associaram-na com o termo "prevalência" que significaria a \% de plantas atacadas, para dar o índice da doença como medida da quantidade presente. Assim quando CHESTER (1950) colocou que avaliar perdas por doença consiste em medir sua intensidade e transferi-la às perdas, definiu intensidade como a quantidade de doença presente na planta, no campo ou numa região geográfica, sem referência ao dano causado. CHIARAPPA (1971) definiu o termo intensidade para cobrir incidência da doença ou a severidade como foi posteriormente

\footnotetext{
5 TEHON, L.R. \& STOUT, G.L. Epidemic diseases of fruit trees in Illinois. Bull. Illinois Dept.
} Registr. and Educ. Div. Nat. Hist. Surv., 17(3):415-502, 1930. 
definida. JAMES (1974), TENG (1985) e KRANZ (1988) definiram incidência da doença como o número de plantas ou parte delas infectadas, expressas como uma \% do número total de unidades analisadas (\% de plantas doentes ou folhas, etc.); consideraram também o termo "severidade" da doença como a área de tecido da planta afetada pela doença, expresso em \% da área total. $\mathrm{O}$ uso de diferentes termos, segundo JAMES (1974), usados para definir medidas de doenças em plantas, resultam em infindáveis e infrutiferas discussões que normalmente ocorrem a respeito do significado dos termos.

GAUNT (1987) conceituou os diversos termos usados para definir aspectos de medição de doenças, como prevalência, incidência, severidade e intensidade. Prevalência é a proporção de unidades de produção na qual ao menos alguma doença ou patógeno pode ser encontrada e é usada em trabalhos de inspeção ou raramente em outros tipos de investigação; incidência é a proporção de plantas ou parte de plantas infectadas, sendo usada mais largamente para patógenos e monitoramento de doenças para diversos propósitos; severidade refere-se à quantidade de tecido danificado sendo o mais usado e a mais diferente forma de medição de doença. Intensidade de doença é usada como um termo geral para a quantidade de doença presente, frequentemente baseada em incidência e/ou severidade.

KRANZ (1988) admitiu que a intensidade de doença pode ser expressa como incidência (ou frequência) ou severidade. A escolha entre a evolução da doença de plantas de acordo com sua incidência ou severidade, depende grandemente do tipo de doença e do objetivo da sua avaliação. Severidade parece ser mais apropriado para doenças como ferrugem, manchas foliares e semelhantes, onde, salvo citações de outra forma, a severidade refere-se ao número de lesões e ao total de área afetada. A avaliação da intensidade da doença conforme sua incidência, é adequada para muitas doenças nos estágios iniciais da sua epidemia, aplicando-se quando elas afetam totalmente a planta. A incidência da doença pode ser avaliada pela 
simples contagem de amostras (unidades doentes e sadias) sendo menos embaraçoso e sujeito a erros que a avaliação de severidade da doença. Unidades de amostra é definida como doente somente se a severidade da doença está além de um certo nivel (limiar de dano fisiológico), e então avaliada como incidência.

Esta terminologia também é analisada por AMORIM (1995), em acordo com as conceituaçōes já mencionadas, considerando, também, que a utilização do termo intensidade, que pode ser expresso como incidência ou severidade, deve ser esclarecido previamente.

No caso presente utilizou-se o critério de intensidade de ocorrência de podridão-abacaxi, significando esta intensidade a extensão dos sintomas de $C$. paradoxa ao longo dos toletes de cana-de-açúcar postos a brotar, conforme a quantidade de tecido atacado, ou seja, conforme a severidade da ocorrência da doença nos tecidos dos toletes.

\subsection{Metodologias para avaliação das relações doenças - perdas em plantas}

CHESTER (1950) em seu trabalho sobre perdas por doenças de plantas acrescentou que, para serem mais úteis, os métodos de avaliação de doenças devem reunir certos requerimentos. Particularmente eles devem se relacionar com as perdas e não apenas com a intensidade da doença, seguindo as seguintes qualificaçōes:

- devem medir a intensidade da doença e relacioná-la com as perdas de colheita;

- devem ser compreensivos;

- devem ter graus práticos de exatidão; 
- devem ser comparáveis a partir de um pesquisador, um local ou de um ciclo para outro da cultura;

- devem ser objetivos;

- devem envolver todas as formas de perdas pela doença em análise.

O método de medição da doença de plantas, conforme as indicações de LARGE (1966), deve variar de acordo com a natureza da doença. Se, porém, um sistema de medição de doença é para ser aplicado em inspeções e estimativas de perdas, então há uma estratégia a seguir, cujos requerimentos são: a) estudo cuidadoso da morfologia e curso do desenvolvimento da cultura em questão, considerando plantas sadias, desde a semeadura até a colheita; b) estudo similar do curso da doença nas plantas no campo, em todos os níveis de ataque; c) esboço de um padrão para avaliação da doença, e depois um simplificado padrão de campo adaptado para uso por outros observadores; d) condução de testes de campo, em diversos anos, nos quais a curva de progresso da doença é comparada com o padrão de campo, registrando-se as produçōes encontradas, para situações onde a doença foi permitida e onde foi controlada por qualquer meio; e) escolha de um particular meio de avaliação da doença, que melhor servirá para definir o ataque quando empregado em trabalhos de inspeção, e calibração destas avaliações em termos de redução da produção.

Após a determinação da intensidade de plantas doentes, é necessário estabelecer a conexão que exista entre esta intensidade da doença e a consequente perda verificada, o que constitui o segundo maior passo em avaliação de doenças de plantas. Para isso, existem vários métodos experimentais que podem ser usados na determinação dos efeitos da doença na produção das plantas, os quais são variações de três pontos básicos: a) produzir ou estimular a doença, comparando estas plantas doentes com plantas sadias tomadas como padrão; b) prevenir a doença e comparar com 
plantas naturalmente infectadas; c) encontrar plantas sadias e doentes e comparar suas produções (CHESTER, 1950).

A meta nesta fase é medir a doença e desenvolver um confiável método de correlação com as perdas provocadas; neste contexto, perda é definida como uma medida de redução em produção elou qualidade, embora nem sempre econômica. Experimentos de campo são mais dificeis de conduzir que aqueles em casa de vegetação, mas são os únicos métodos disponiveis para estudar os efeitos de uma doença na produção em condições de campo. No seu trabalho sobre avaliação de perdas por doenças em plantas, JAMES (1974) considerou que a estratégia geral para isso foi descrita por CHESTER (1950), LARGE (1966) e pela FAO (1971) e envolve duas fases: a) experimento de campo para caracterizar as conexões entre a doença e as perdas no campo, de forma que um método confiável pode ser desenvolvido para estimar as perdas associadas com uma determinada quantidade de doença. Esta fase envolve estudos da doença durante o ciclo de desenvolvimento, e monitoramento das populações das plantas sadias e doentes. Padrōes de desenvolvimento para os diferentes estágios da planta são preparados, e métodos de avaliação são desenvolvidos para medir a doença. Independente de que método de avaliação é usado, os padrões definidos devem designar nos vários registros, valores similares para a mesma cultura doente. Uma série de ensaios é conduzido, e em cada ensaio a doença é permitida em alguns blocos e controlada em outros. O passo final é desenvolver um confiável método para estimar as perdas de produção para uma dada quantidade de doença ou uma dada curva de seu progresso. Para uso prático, um método deve ser aplicável sob determinadas condições, e exceções devem ser anotadas para que as necessárias correçōes sejam feitas; b) a segunda fase envolve a avaliação da doença em inspeção numa série de campos, usando o método desenvolvido na primeira fase. Pelo conhecimento da conexão 
quantitativa entre doença e a produção verificada, a perda pode ser calculada a partir dos dados de doença registrados na inspeção.

Para a geração de dados básicos para a construção de modelos de avaliação de perdas por doenças, SHANE \& TENG (1987) definiram que entre todas as técnicas relatadas na literatura, a de parcelas experimentais utilizando um delineamento padrão, são as mais comuns. Juntamente com SAH \& MACKENZIE (1987), e JAMES \& TENG (1979), descreveram diversas formas de obtenção de diferentes niveis de doença no campo entre os quais a utilização de produtos químicos, resistência diferencial do hospedeiro e práticas culturais, sendo o número de repetiçōes aplicados em experimentos pareados ou múltiplos de no mínimo três.

\subsection{Modelos para estimar perdas de produção agrícola causadas por doenças}

As informações de JAMES (1974) conduzem a análise das relações doença-produção-perdas de forma bastante objetiva. Segundo ele, no contexto de avaliação de perdas, doenças são estimadas somente como um meio de medir e prevenir perdas. O mais simples método de avaliação da doença é usualmente o menos propenso a erro.

A grande quantidade de dados gerados em experimentos de avaliação de perdas provocadas por doenças em plantas, é difícil de ser interpretada e usada, a menos que tais dados possam ser sintetizados numa relação quantitativa chamada de modelo (JAMES \& TENG, 1979).

Modelos são convenientes meios de sumarizar dados numa forma prática e concisa, comumente uma equação. A equação simplifica o cálculo de perdas a partir de conhecidas quantidades de doença, num 
especifico estádio de desenvolvimento da planta, e facilita a racionalização dos processos biológicos essenciais (Gaunt ${ }^{6}$, citado por TENG, 1981).

Existindo um modelo que capture a essência de como a doença afeta a produção e suas perdas, é possivel promover outros objetivos como a formulação de limites econômicos para o controle. A complexidade da relação doença-perda é aumentada com múltiplas doenças, ou quando outras pragas e efeitos ambientais são incluídos como variáveis de explicação das perdas de produçāo (TENG, 1987). Este mesmo autor considerou que, enquanto muitos métodos estatísticos estejam disponíveis para quantificar as relações doençaperdas, é importante que a biologia básica da conjunção doença-perdas não seja sacrificada por razões estatísticas. Um modelo pode ser considerado a representação de um sistema definido numa forma diferente do original. Modelos simbólicos, que representam um sistema ou sintetizam dados sobre um sistema, usando matemática, são os mais comuns em proteção de plantas. Quando uma certa e conhecida "entrada" é feita, a maioria dos modelos são capazes de prognosticar uma "saida", com limites conhecidos de confiança. Em avaliação de perdas "entradas" são comumente parâmetros da doença e "saídas" as produções ou perdas.

JAMES (1974) e JAMES \& TENG (1979) admitiram que modelos matemáticos de conexão entre a doença e as perdas de produção provocadas podem ser divididos em dois grupos: a) Modelo do Ponto Crítico proporciona estimativa de perda para um dado nível da doença num dado momento, ou num determinado tempo quando uma quantidade particular da doença é atingida; b) Modelo de Múltiplos Pontos - estima perdas para uma curva de progresso da doença, consistindo em várias avaliações desta doença. Um terceiro tipo de modelo relacionando a Área sob a Curva de Progresso da

${ }^{6}$ GAUNT, R.E. Crop physiology; diseases effects and crop loss. In: APPS WORKSHOP ON EPIDEMIOLOGY AND CROP LOSS ASSESSMENTS, Lincoln College, 1977. Proceedings. p.9.1-9.12. 
Doença (AUDPC) com as perdas é admitido, e considerado como sendo um misto entre o Modelo do Ponto Crítico e o Modelo de Múltiplos Pontos. O Modelo do Ponto Crítico consiste em equações obtidas por regressões lineares, onde a variável independente é a medida da doença e a porcentagem de perdas na produção é a variável dependente, enquanto no Modelo de Múltiplos Pontos a doença é avaliada durante sua epidemia, como forma de suprir a limitação da avaliação em um único ponto chamado "crítico".

Modelo é a representação de um sistema que reproduz uma parte da realidade (Teng e Zadocks ${ }^{7}$ citados por BERGAMIN F' \& AMORIM, 1991). Citações destes autores consideraram que os "principais modelos matemáticos que estabelecem uma relação direta entre doenças e perdas são: Modelo do Ponto Crítico (JAMES, 1974), Modelo de Múltiplos Pontos (JAMES, 1974). Área sob a Curva de Progresso da Doença - AUDPC (VANDERPLANK, 1963) e Modelo de Superfície-Resposta (MAIN, 1978)", conforme informações derivadas de $\mathrm{Kranz}^{8}$.

TENG (1981) assentiu que a maioria dos modelos de perdas por doenças são modelos empíricos de regressão, onde $y=f(x)$, com a variável dependente $(y)$ sendo uma função da variável independente. $O$ valor de $Y$, comumente \% de perdas, é uma função de um ou mais valores de $x$, normalmente \% de intensidade da doença. Os modelos de regressão são representaçōes estatísticas do efeito da doença na produção, mas não podem ser consideradas evidências de afinidades causais. Análises de regressão Isão análises lineares multivariadas, cuja limitação poderia ser identificada uma vez que muitos processos biológicos não são lineares. A transformação da variável independente numa regressão, para aperfeiçoar o modelo ajustado

\footnotetext{
7 TENG, P.S. \& ZADOCKS, J.C. Computer simulation of plant disease epidemics. In: YEARBOOK of Science and Tecnology. New York, McGraw - Hill, 1980. p.23-31.

8 KRANZ, J. The role and scope of mathematical analysis and modeling in epidemiology. In: KRANZ, J. ed. Epidemics of plant diseases; mathematical analysis and modeling. Berlin, Springer-Verlag, 1974. p.7-54.
} 
aos dados, como numa regressão polinomial, não muda a natureza inerentemente linear da análise de regressão múltipla.

É também de TENG (1981) a confirmação que todo modelo de regressão doença-perda pode ser incluído em uma das três categorias: a) Modelo do Ponto Crítico ou Único; b) Modelo de Pontos Múltiplos e c) Modelo da Área sob a Curva de Progresso da Doença. Para os três modelos, a variável dependente, isto é, a variável para a qual as estimativas são requeridas, é a perda de produção, comumente expressa como uma \%. Com o Modelo do Ponto Único, a perda é estimada a partir da intensidade da doença num estádio de crescimento; no Modelo de Pontos Múltiplos, a perda é estimada usando-se diversas determinações da doença, feitas sequencial e progressivamente nos estádios de crescimento da planta; o Modelo da Área sob a Curva de Crescimento da Doença, estima as perdas a partir da área debaixo da curva citada.

TENG (1985) relacionando trabalho anterior de sua autoria, sugeriu que modelos de previsão de perdas podem ser categorizados em empíricos, explanatório ou explicativo e conceitual. Empíricos têm sido aplicados largamente para avaliação de perdas e são desenvolvidos a partir de dados de experimentos de campo; modelos de simulação de perdas por doença requerem um modelo explicativo de produção para previsão do efeito de uma doença, e modelo conceitual utiliza o conhecimento da fisiologia da produção e os efeitos das doenças na produção para propor prováveis respostas de perdas. Os modelos empíricos são os seguintes: ponto único (ou crítico), múltiplos pontos, área sob a curva de progresso da doença, superfícieresposta, sinecológico e integral. Além dos modelos já mencionados anteriormente, foram adicionalmente citados o modelo superfície-resposta que estima perda de produção a partir de dois diferentes tipos de "entrada" de dados a partir da epidemia ou do hospedeiro, segundo a equação geral $y=f(x$, t) onde $x$ é a severidade da doença e t o estádio de desenvolvimento do 
hospedeiro; o modelo Integral define as perdas a partir da "entrada" de variáveis que representam a doença para uma definida duração da epidemia, como a área sob a curva de progresso da doença (AUDPC); o modelo sinecológico, termo este introduzido por Stynes $^{9}$, estima perdas de produção as quais incorporam todas as variáveis independentes numa equação, e permite a construção de modelos para múltiplos fatores limitantes da produção, bióticos ou abióticos (TENG \& JOHNSON, 1988; BERGAMIN Fo, 1995).

Segundo TENG (1987) os modelos de prognóstico único são melhor aplicados para doenças de curta duração, que afetam somente um componente da produção como peso dos grãos. Estes modelos admitem que as perdas podem ser estimadas pelo conhecimento da quantidade de doença em um ponto no crescimento da planta, implicando que o curso da epidemia antes e depois deste ponto, é estável e prognosticável entre ciclos da cultura. Alguns autores consideraram que há uma fase na vida da plantação em que ela é particularmente sensível à doença - um ponto crítico (JAMES, 1974).

TENG (1987) analisando modelos empíricos lineares admitiu que em modelos de prognóstico único, há uma variável independente " $x$ ", a partir da qual a perda é prevista. A variável " $x$ " tem sido representada de três modos:

a) como intensidade da doença em um único ponto crítico, do ciclo da cultura; b) como o número de dias livres da doença antes de um pré-definido e crítico limite de injúria alcançado, e

c) como um valor integral de unidades da doença através de específico periodo (área sob a curva de progresso da doença). O primeiro tipo de modelo de prognóstico único é exemplificado pela equação que estima perdas causadas por bruzone em arroz: $y=0,57 x$, onde $x$ é a porcentagem de nós atacados 30 dias após a floração e y é a porcentagem de perda na produção, equação esta

\footnotetext{
${ }^{9}$ STYNES, B.A. A synoptic study of wheat. Adelaide, 1975. (Ph.D. - University of Adelaide).
} 
obtida por Katsube e Koshimizu ${ }^{10}$ e citado também por JAMES (1974). O segundo tipo de modelo de prognóstico único é exemplificado pela equação para estimar perdas causadas pela requeima na batata, $y=234,0+1,706 x$, onde $x$ é o número de dias livres da doença e y é a produção de batatas em tha, conforme trabalho de Olofson ${ }^{11}$ citado igualmente em JAMES (1974) e TENG (1985). O terceiro tipo de modelo com variável $x$ única é exemplificado como o modelo da área sob a curva de progresso (AUDPC) da ferrugem do talo do trigo, inicialmente proposto por Vanderplank ${ }^{12}$. AUDPC é quantificada em unidades dependentes arbitrárias da escala usada para marcar as curvas de progresso da doença.

O Modelo do Ponto Único utiliza uma variável independente para estimar as perdas, variável esta que deve refletir toda a epidemia (TENG \& JOHNSON, 1988). BERGAMIN Fo (1995) analisando este tipo de modelo, considerou que para muitas doenças é possivel identificar um determinado estádio de desenvolvimento do hospedeiro no qual a intensidade da doença presente está altamente correlacionada com o dano futuro. Exemplo clássico deste modelo foi publicado por Romig e Calpouzas ${ }^{13}$, citados por JAMES (1974), TENG (1985) e BERGAMIN Fo (1995), para o sistema trigo - Puccinia graminis f. sp tritici, relacionando injúria com dano: $\%$ Dano $=-25,33+27,17$ $\ln (x)$, onde $x$ é a severidade da doença num determinado estádio. Trabalho semelhante com o sistema milho - Helminthosporium maydis feito por Ayers et al. ${ }^{14}$, citados por BERGAMIN Fo (1995), relacionando injúria com produção:

10 KATSUBE, T. \& KOSHIMIZU, Y. Influence of blast disease on harvests in rice plant; 1. Effect of panicle infection on yield components and quality. Bull. Tohoku Nat. Agr. Expa. Sta., (39):55-96, 1970.

11 OLOFSON, B. Determination of the critical injury threshold for potato blight (Phytophtora infestans) Medd. Waxtskyddsanst, Stockholm, 14:81-93, 1968.

12 VANDERPLANK, J.E. Plant diseases; epidemics and control. New York, Academic Press, 1963. 349p.

13 ROMIG, R.W. \& CALPOUZAS, L. The relationship between stem rust and loss in yield of spring wheat. Phytopathology, 60:1801-5, 1970.

14 AYERS, J.E.; NELSON, R.R.; CASTOR, L.L.; BLANCO, M.H. Yield losses in corn caused by Helminthosporium maydis race T. Plant Disease Reporter, 60:331-335, 1976. 
$P=9,3-0,04 x$, onde $P$ é a produção em toneladas por hectare e $x$ é a severidade da doença aos 73 dias da cultura.

\subsection{Avaliação de modelos para estimar perdas por doenças de plantas}

Segundo JAMES \& TENG (1979), as equações matemáticas usadas para descrever os modelos de perdas de produção, simplificam o cálculo das perdas e facilitam a racionalização biológica do fenômeno envolvido. Antes, porém, de ajustar-se uma equação de regressão deve-se verificar que não há falta de normalidade nos dados.

Da mesma forma, TENG (1981) sugeriu que para um modelo ser ajustado aos dados, deve-se verificar que não haja desvios nesses dados a partir da normalidade. Análises de regressão múltipla, em seu senso estrito, não permitem alguma variação na variável independente, isto é, na mensuração da doença. Em avaliações de perdas por doenças esta regra tem sido desconsiderada, pois é comumente impossivel obter uma medida absoluta da doença. Em consequência disto, tendo notado variação na variável independente, deve-se assegurar que outra regra não é quebrada que a da normalidade.

Koutsoyiannis $^{15}$ citado por TENG (1981), considerou que qualquer modelo de regressão assume que os dados básicos dos quais ele foi derivado tem variação uniforme, uma condição chamada homocedasticidade, sendo ignorado pequeno desvio nesta condição antes de caracterizar a situação alternativa, ou seja, a heterocedasticidade.

JAMES \& TENG (1979) consideraram que para julgar a aceitação da equação de regressão, diversas estatísticas podem ser usadas

15. KOUTSOYIANNIS, A. Theory of econometrics; an introductory exposition of economeric methods. London, Mac Millan, 1973. 
como $r^{2}$ (coeficiente de determinação múltipla), $r$ (coeficiente de correlação), $F$ e $t$ (testes estatisticos) e s (erro padrão da estimativa da variável dependente). Segundo estes autores o coeficiente de determinação $r^{2}$ é, provavelmente, o mais importante indicador da confiabilidade do modelo de regressão. Consideraram que uma equação derivada de um Modelo do Ponto Crítico com baixo $r^{2}$, mostrará grande melhora quando mais avaliaçōes da doença forem adicionadas como variável independente transformando-o num Modelo de Múltiplos Pontos. $O r^{2}$ é calculado através da relação entre a soma dos quadrados da regressão e a soma total dos quadrados, e é considerado a proporção da variação total da variável dependente que é explicado pela variável ou variáveis independentes. Para um $r^{2}=0,90$, por exemplo, a equação de regressão explicaria $90 \%$ da variação total dos valores de $\%$ de perdas de produção em torno da sua média; os $10 \%$ restantes da variação total em perdas da produção não é explicada pelo modelo e devido a erros do acaso ou variáveis indefinidas.

Informações de TENG (1981) admitiram que diversas estatísticas ou testes têm sido usados para avaliação dos modelos de regressão de perdas de produção, tais como:

a) 0 " $r^{2 n}$ estatístico - coeficiente de determinação múltipla;

b) o teste $F$ na análise de variância;

c) $O$ " $s$ " estatístico - erro padrão da estimativa da variável dependente;

d) o " $r$ " estatístico - coeficiente de correlação múltipla, e

e) o teste $t$

A interrelação entre as primeiras quatro estatisticas, pode ser mostrada considerando seu cálculo nas análises de variância para avaliação de regressão múltipla, conforme apresentado a seguir : 


\begin{tabular}{lccc}
\hline $\begin{array}{r}\text { Fonte de } \\
\text { variação }\end{array}$ & $\begin{array}{c}\text { Graus de } \\
\text { liberdade }\end{array}$ & $\begin{array}{c}\text { Soma de } \\
\text { quadrados }\end{array}$ & $\begin{array}{c}\text { Quadrado } \\
\text { Médio }\end{array}$ \\
\hline Regressão & $\mathrm{K}$ & $\mathrm{A}$ & $\mathrm{A} / \mathrm{K}$ \\
Desvio & $n-1-\mathrm{K}$ & $\mathrm{B}$ & $\mathrm{B} /(\mathrm{n}-1-\mathrm{K})$ \\
Total & $n-1$ & $\mathrm{~A}+\mathrm{B}$ & $(\mathrm{A}+\mathrm{B}) /(\mathrm{n}-1)$ \\
\hline
\end{tabular}

$\mathrm{Na}$ representação acima, $\mathrm{n}=$ número de observações, $\mathrm{K}=$ número de variáveis independentes por regressão, e $A$ e $B$ são valores arbitrários usados como exemplo. A base da análise de variância para regressões múltiplas é que a variação total em valores observados da variável ou variáveis dependentes, podem ser divididas em duas fontes: a) variação devida a desvios nos valores de y previstos a partir da média de $y_{;}$e b) variação devido a desvios nos valores de y observados a partir dos valores de y previstos.

Os critérios propostos por TENG (1981) para avaliação dos modelos tem as seguintes definiçōes:

a) $\mathrm{O}$ " $\mathrm{r}^{2 n}$ estatístico, o qual indica a proporção de variação total da variável dependente (\% de perda na produção) que é explicado pela variável independente (quantificação da doença), é provavelmente o mais importante indicador de quão seguro e confiável o modelo é:

$$
r 2=\frac{A}{(A+B)}=\frac{\text { Soma dos Quadrados de Regressao }}{\text { Soma Total de Quadrados }}
$$

O valor real de $r^{2}$ para aceitação do modelo é deixado ao experimentador. Muito embora o $r^{2}$ seja uma estatística importante, ele deve ser usado cuidadosamente. Por exemplo, $r^{2}$ pode ser a unidade (100\%), pelo emprego de $n$ parâmetros selecionados particularmente no modelo, como 
quando $n$ aproxima-se de um ponto de saturação igual ao número de observações (Koutsoyiannis ${ }^{16}$ ). Também o aumento de transformações da mesma variável no modelo, pode dar valores altos de $r^{2}$ enganosamente, e produzir um modelo que é biologicamente insustentável;

b) $O$ " $r$ " estatistico, derivado da raiz quadrada de $r^{2}$, pode ser testado para significância em niveis de probabilidade definidos. Esta é uma estatística adicional, que descreve quanto bons os dados originais ajustam-se à equação;

c) O teste $\mathrm{F}$ em análises de variância é numericamente calculado como:

$$
F=\frac{A / K}{B /(n-1-K)}=\frac{\text { Quadrado Medio da Regressao }}{\text { Quadrado Medio dos Desvios }}
$$

O teste indica que toda a significância do modelo é atribuída aos efeitos combinados de suas variáveis independentes, e pode ser testado a niveis de $5 \%$ ou $1 \%$ de probabilidade. A significância do $\mathrm{F}$ não define um bom modelo de previsão desde que $r^{2}$ pode ser baixo ao mesmo tempo. Isto pode acontecer quando o número de observaçōes, $n$, usado, é grande, como um ensaio sem repetições, resultando num relativamente baixo quadrado médio dos desvios para o cálculo de $F$;

d) 0 " $s$ " estatístico mede a precisão da estimativa da variável dependente (perda de produção) e é calculado como:

$$
s=(\text { quadrado médio dos desvios })^{1 / 2}
$$

Os menores valores de $s$, terão os mais exatos valores previstos pelo modelo, conforme os valores observados. Entretanto, como em $r^{2}$, s pode ser zero pela inclusão de diversos parâmetros;

16 KOUTSOYIANNIS, A. Theory of econometrics; an introductory exposition of econometric methods. London, Mac Millan, 1973. 
e) o teste $t$ é usado para testar a significância de uma parte do coeficiente da regressão, relacionado à sua contribuição com a significância do modelo.

\subsection{Teste de modelos de perdas na produção agrícola}

As afirmações de TENG (1981) consideraram que a capacidade de previsão de um modelo de regressão de perdas por doença, é em parte estabelecido durante o processo de desenvolvimento do modelo. Estatísticas como $r^{2}$ e s, em particular, indicam a exatidão do modelo. Isto é válido somente para os dados básicos usados para a regressão e implicitamente para a extensão da produção e fatores ambientais cobertos pelo experimento de campo. O que não é estabelecido é a capacidade do modelo de fazer aceitáveis estimativas de perdas, usando avaliações da doença que não foram utilizadas como variável independente no desenvolvimento do modelo.

TENG (1987), relatou que modelos de regressão de perdas por doenças são avaliados para significância da sua afinidade usando-se o $F$ estatístico. $O$ coeficiente de determinação $r^{2}$ não é testado para significância, e um valor de $r^{2}=0,80$ é considerado um bom modelo, especialmente se os dados usados para a regressão foram derivados de diversos locais, diferentes cultivares e por dois a três ciclos.

Ainda segundo TENG (1981), duas aproximações podem ser seguidas para o subsequente teste do modelo. Um é usar o modelo como parte de um programa amplo de avaliação de perdas e subsequentemente medir a resposta do modelo em diversas épocas (anos). Uma segunda aproximação é usar testes estatísticos para checar a boa qualidade da adaptação entre o modelo de previsão e dados observados de perdas de 
produção. Uma dificuldade geralmente encontrada é que, para originar a figura de perda de produção, deve-se ter o controle (zero de doença), o que frequentemente não é possivel, exceto em experimentos planejados. Um procedimento simples é locar a estimativa do modelo ( $y^{\prime \prime}$ ) em contraste com os dados de perda observados $(y)$, e efetuar a regressão linear nos dados. A melhor linha de adaptação teórica passa pela origem e tem um gradiente de 1,0 (inclinação de $45^{\circ}$ aos eixos).

KRANZ (1988) considerou que para caracterizar as estimativas individuais, uma regressão linear pode se adaptar às estimativas, sendo o coeficiente de determinação $r^{2}$ usado como medida de adequação ao redor da linha de regressão, sendo que estimativas são precisas se $r^{2}$ estiver próximo a 0,95 .

Pouca pesquisa tem sido conduzida em testes de modelos de perdas por doença em plantas, e em muitos casos, modelos têm sido aceitos para uso até que fique provado que não são confiáveis (TENG, 1981). 


\section{MATERIAL E MÉTODOS}

Para o presente propósito de interpretar a ocorrência da podridão-abacaxi em toletes de cana-de-açúcar, correlacionada com as respectivas perdas provocadas na produção final da cultura, em conformidade com a incidência da doença no período crítico do ciclo da planta e, também avaliar diferentes métodos de plantio como tratamento cultural ao ataque do fungo $C$. paradoxa, planejou-se um ensaio de campo, onde foram provocadas as situaçס̃es que permitissem diferentes niveis da doença nos toletes plantados, a partir dos procedimentos de implantação dos tratamentos projetados.

\subsection{Local}

Escolheu-se para instalar o ensaio de campo, áreas de cultivo da cana-de-açúcar com histórico de ocorrência comprovada de C. paradoxa. Para isto, utilizou-se dos campos experimentais da Estação Experimental de Cana-de-açúcar, pertencente ao ex-IAAPLANALSUCAR e, atualmente, local do Centro de Ciências Agrárias da Universidade Federal de São Carlos CCA/UFSCar, em área de solo Latossolo Roxo distrófico. 
A área experimental está localizada na Latitude de $22^{\circ} 18^{\prime} \mathrm{S}$ e Longitude de $47^{\circ} 23^{\prime} \mathrm{W}$, apresentando altitude média de 617 metros e classificação climática Cwa (Koppen), mesotérmico, caracterizado por verões quentes e úmidos, e invernos secos.

\section{2. Época de plantio}

Os trabalhos de montagem do ensaio de campo foram efetivados em 20 de abril de 1983, portanto em pleno outono, quando as temperaturas médias começam a declinar e a umidade do solo apresenta alternâncias, desde seca relativa até o encharcamento, conforme os índices climatológicos do período (Apêndices 1 e 2).

\subsection{Variedades de cana-de açúcar selecionadas}

Foram utilizadas as variedades NA56-79, RB725828 e RB735275, com o objetivo de se ter diferentes niveis de resistência à Podridão Abacaxi. Esta resistência está associada a diferentes caracteristicas culturais destas variedades, as quais apresentam maior ou menor velocidade de emergência ( brotação inicial) das gemas plantadas, ficando diferentemente expostas ao ataque de C. paradoxa. No caso, a RB735275 apresenta brotação

inicial mais rápida quando comparada às demais, e a RB725828 superior à variedade NA56-79.

\subsection{Indução de diferentes niveis de incidência de $C$. paradoxa}

Para se obter o desejado gradiente de incidência da doença para conexão desta com suas respectivas perdas, conforme estratégia descrita por CHESTER (1950), LARGE (1966), FAO (1971) e JAMES (1974), utilizou- 
se, além das diferentes caracteristicas das variedades escolhidas para o ensaio de campo, de sistemas de plantio que possibilitassem um gradiente de incidência e desenvolvimento do fungo $C$. paradoxa ( MATSUOKA \& GHELLER, 1984 ).

Implementou-se nas parcelas experimentais, cinco tratamentos, com a aplicação de proteção química (HILTON et al., 1971; IAAPLANALSUCAR, 1973; 1974 e 1975; WISMER \& BAILEY, 1989), bem como métodos culturais que possibilitassem maior proteção das gemas, com o uso de toletes de maior comprimento (VAN DILLEWIJN, 1951; WISMER \& BAILEY, 1989). Os tratamentos estipulados foram:

a) Cana picada em toletes de três gemas sem aplicação de fungicidas;

b) Cana picada em toletes de três gemas, com aplicação do fungicida Benlate (Benomyl - $37 \mathrm{~g}$ do i.a. $/ 100$ litros de água) ou $65 \mathrm{~g}$ do produto comercial por 100 litros de água, em imersão durante dez minutos;

c) Cana picada em toletes de seis gemas;

d) Cana picada apenas em seu terço superior, resultando num pedaço com 12 gemas (2/3) e o terço superior com 6 gemas;

e) Cana inteira com 18 gemas.

Para todos os tratamentos utilizou-se de colmos com 18 gemas, distribuindo-se entre 12 e 12,6 gemas por metro linear de sulco plantado.

\subsection{Delineamento Experimental}

O ensaio de campo foi conduzido em parcelas subdivididas, objetivando-se estudar dois tipos de tratamentos (PIMENTEL GOMES, 1970), no caso, variedades e diferentes técnicas culturais de plantio da cana-deaçúcar. Tal delineamento permite ampliar o propósito deste trabalho, 
incorporando a avaliação dos fatores "variedades" e "sistemas de plantio", conjuntamente ( BANZATTO \& KRONKA, 1992 ).

Assim, projetou-se o delineamento em quatro repetições (blocos), onde foram distribuidas as variedades (parcelas) e tratamentos para diferentes niveis de incidência de C. paradoxa (sub-parcelas).

\subsection{Tamanho das sub-parcela}

Foram implantadas sub-parcelas com 6 sulcos de 10 metros de comprimento num espaçamento de $1,40 \mathrm{~m}$, ou $84 \mathrm{~m}^{2}$ por sub-parcela experimental.

\subsection{Parâmetros avaliados}

\subsubsection{Parâmetros para estimar a incidência de C. paradoxa}

Para avaliar a presença de C. paradoxa, conforme seu nivel de ocorrência nos diferentes tratamentos, utilizou-se de um dos seis sulcos de cada sub-parcela, cujos toletes foram arrancados aos 70 dias do plantio, e examinados visualmente quanto à presença de $C$. paradoxa e extensão dos seus danos. Empregou-se uma escala numérica variando de 1 a 4 para as seguintes observações :

1. Ausência ou início de infecção

2. Infecção em até $1 / 3$ da extensão do tolete

3. Infeç̧ão superior a $1 / 2$ da extensão do tolete

4. Infecção em toda a extensão do tolete 


\subsubsection{Parâmetros para estimar as perdas provocadas por C. paradoxa}

Além da avaliação da incidência de $C$. paradoxa aos 70 dias do plantio, coletou-se durante o ciclo da cultura, em cana-planta e cana-soca, outros dados que permitiram caracterizar a produção agrícola para os diferentes tratamentos, quais foram :

- Brotação inicial das gemas plantadas, aos 50 dias do plantio;

- Número de perfilhos existentes aos 110, 200 e 310 dias após o plantio;

- Número de falhas de plantio, anotadas aos 195 dias do plantio;

- Comprimento total das falhas observadas;

- Número de colmos industrializáveis observados à época das colheitas;

- Produção agricola em toneladas por hectare (t/ha).

\subsection{3. Época das colheitas}

Cana-planta em 03 de Setembro de 1984, portanto, aos 16,5 meses após o plantio.

Cana-soca em 24 de Setembro de 1985, aos 12,5 meses após o primeiro corte.

\subsubsection{Análises estatisticas}

Os dados foram processados com auxílio do Departamento de Matemática e Estatística da ESALQ/USP, através do programa SANEST Sistema de Análise Estatística.

A adequação dos dados de produção agrícola e perdas associados à incidência de $C$. paradoxa foram realizadas através do Microsoft Graph 5.0. 


\section{RESULTADOS E DISCUSSÃO}

\subsection{Avaliação da intensidade de ocorrência de podridão-abacaxi}

$\mathrm{Na}$ Tabela 1, são apresentadas as frequências de notas de intensidade de podridão-abacaxi, observadas em todas as parcelas do ensaio de campo. $\mathrm{Na}$ Tabela 2, são apresentadas apenas as frequências de notas relativas a cada tratamento / variedade, seguida da intensidade (\%) calculada, também, para cada tratamento / variedade, e o valor médio geral da intensidade (\%) de podridão-abacaxi incidente nos toletes plantados, para cada tratamento estudado.

A intensidade (\%) pode ser interpretada como a quantidade de tecido afetado pelo fungo $C$. paradoxa, agente causal da podridão-abacaxi, em relação à quantidade total de tecido vegetal (toletes) plantado.

O critério adotado para a transformação da notas aplicadas, em intensidade (\%) de podridão-abacaxi, leva em consideração a severidade dos sintomas observados em cada tolete analisado, segundo a representatividade de cada nota da escala. Assim, para nota 1, -"ausência ou início de infecção"considerou-se severidade de $10 \%$ nos tecidos dos toletes; para nota 2, "infecção em até $1 / 3$ do tolete"-considerou-se severidade de $33 \%$ nos tecidos 


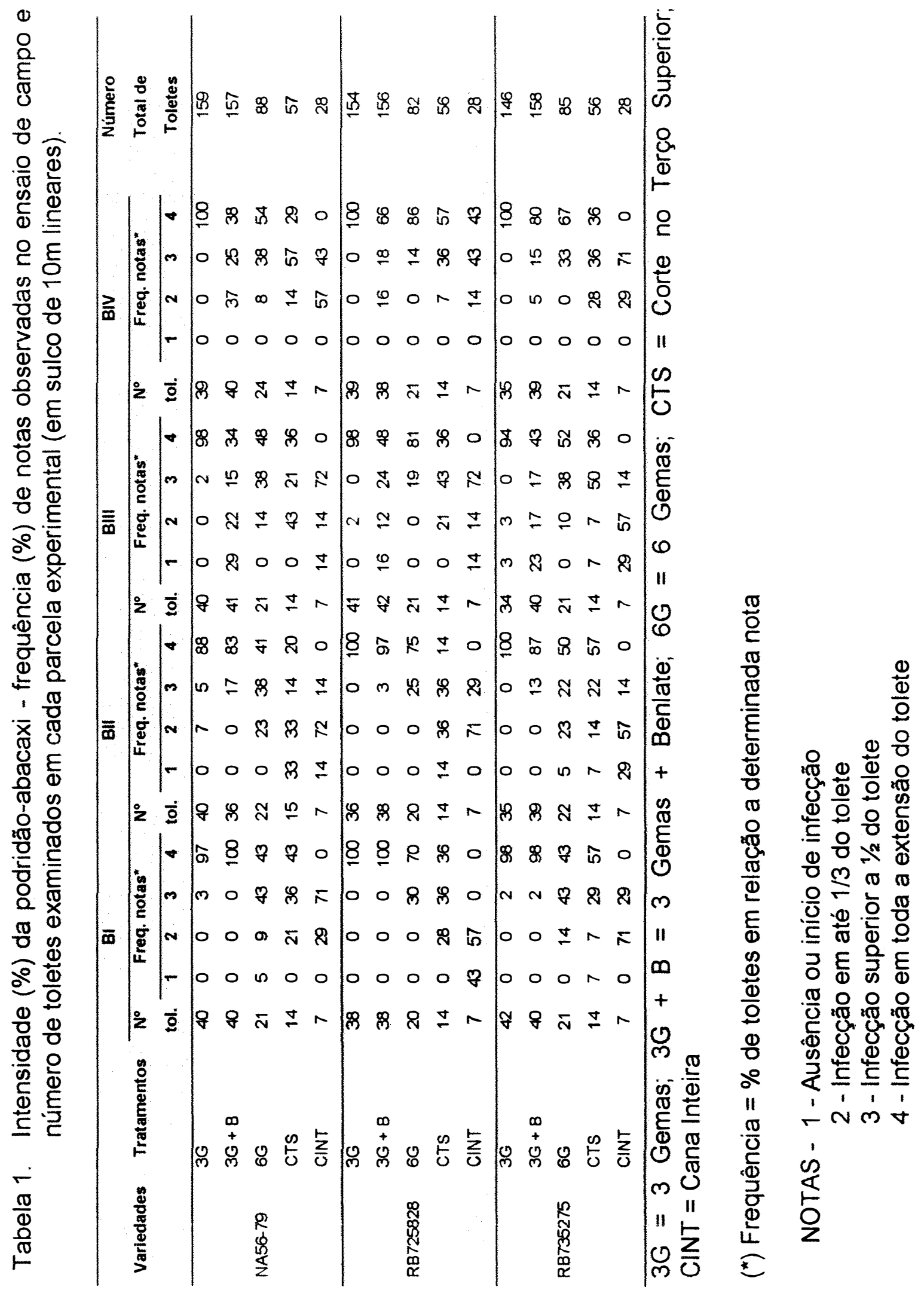




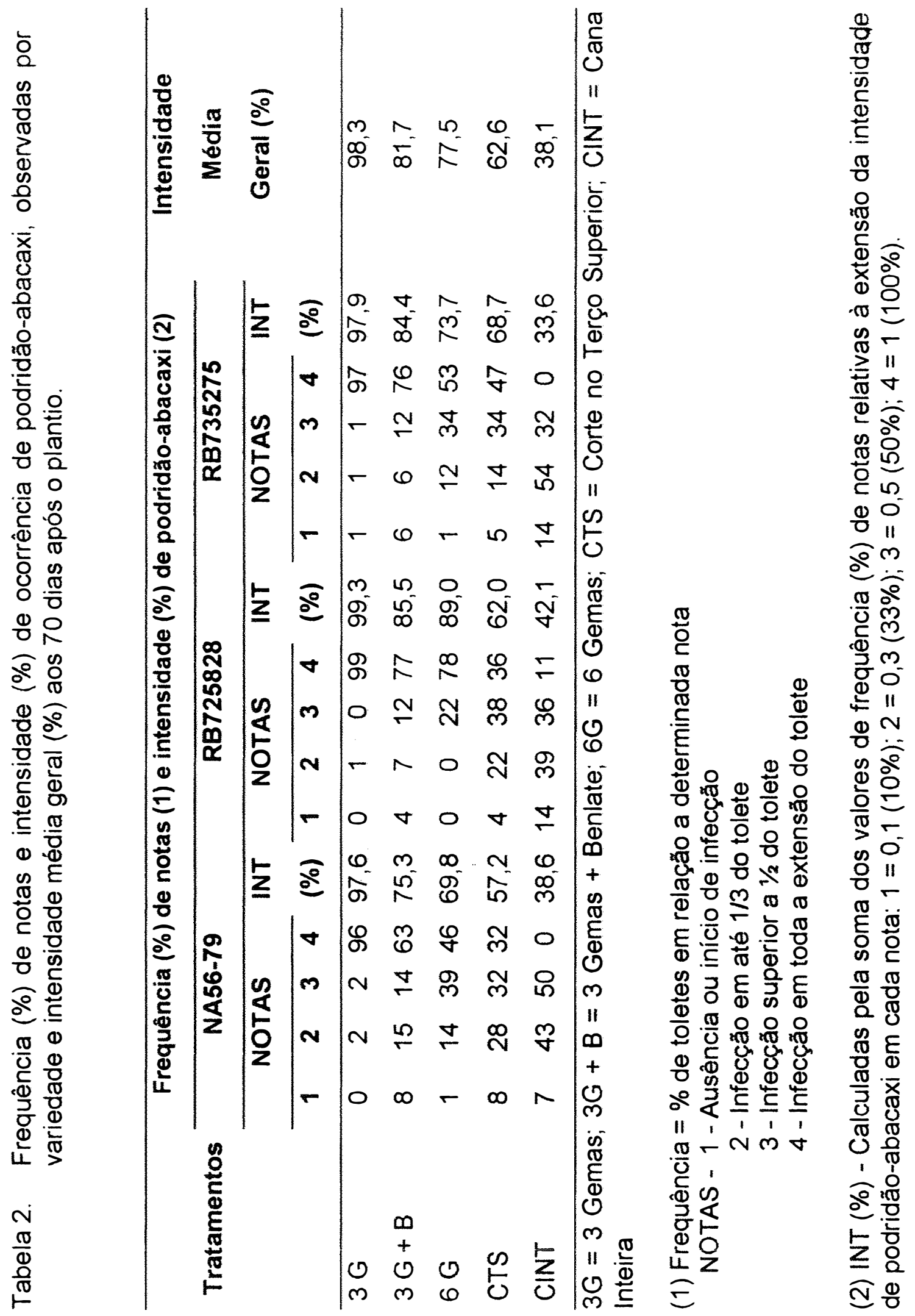


dos toletes; para nota 3, -"infecção superior a $1 / 2$ do tolete"-considerou-se severidade de $50 \%$, e a nota 4 , representou severidade em $100 \%$ dos tecidos dos toletes contaminados, em conformidade com a aplicação visual utilizada na prática, para a avaliação dos sintomas.

Para confirmar a precisão do método aplicado, confrontou-se os resultados de intensidade (\%) de podridão-abacaxi obtidos (Tabela 2 ), com aqueles calculados matematicamente, a partir da relação quantitativa entre áreas de tecido vegetal com e sem sintomas da doença, segundo a severidade que cada nota representa, conforme exemplo a seguir :

\author{
Variedade - NA56-79 \\ Tratamento - Cana Inteira \\ Número de colmos plantados/amostrados - 28 colmos
}

\begin{tabular}{ccccc}
$\begin{array}{c}\text { NOTA Frequência } \\
\text { de Notas }\end{array}$ & $\begin{array}{c}\text { Severidade } \\
\text { atribuida }\end{array}$ & $\begin{array}{c}N^{\circ} \text { de colmos } \\
\text { p/ cada nota }\end{array}$ & $\begin{array}{c}N^{\circ} \text { de colmos } \\
\text { infectados }\end{array}$ \\
\hline 1 & $7 \%$ & $10 \%$ & 2 & 0,20 \\
2 & $43 \%$ & $33 \%$ & 12 & 3,96 \\
3 & $50 \%$ & $50 \%$ & 14 & 7,00 \\
4 & $0 \%$ & $100 \%$ & 0 & 0,00 \\
\multicolumn{2}{l}{ Total } & & 28 & 11,16 \\
\hline
\end{tabular}

Em 28 colmos do tratamento Cana Inteira, variedade NA56-79, observou-se 11,16 colmos totalmente infectados, o que corresponde a $39,86 \%$ de intensidade de podridão-abacaxi. Segundo o método utilizado neste trabalho, a intensidade de infecção foi avaliada em 38,60\% (Tabela 2), portanto bastante próxima daquela calculada teoricamente; a intensidade (\%) 
apresenta-se rigorosamente igual para tratamentos de maior nivel de seccionamento do colmo plantado, portanto com intensidade (\%) maior, comparando-se as duas formas de cálculo para estimar a infecção de $C$. paradoxa.

A ocorrência de outros microrganismos patogênicos nos colmos de cana-de-açúcar plantados, e que poderiam, também, causar danos à brotação inicial das gemas, não interferiu neste estudo, pelo conhecimento dos organismos comumente associados aos toletes em processo de brotação nas diversas regiões canavieiras de Estado de São Paulo, como também, pelo potencial de inóculo de C. paradoxa no solo do local do ensaio. Além disso, a diagnose de campo da podridão-abacaxi, através de seus sintomas caracteristicos, foi facilitada pela avaliação aos 70 dias do plantio, quando o fungo já apresentava intensa esporulação, acompanhado do aroma inconfundivel da doença.

Pela Tabela 2, pode ser observado a tendência de intensidade (\%) podridão-abacaxi ser decrescente no sentido do tratamento 3 Gemas para o tratamento Cana Inteira, ou no sentido dos tratamentos de maior índice de seccionamento dos colmos para os de menor seccionamento. A única exceção desta tendência foi na variedade RB725828 entre os tratamentos 3 Gemas + Benlate e 6 Gemas, onde este último apresentou intensidade (\%) de podridãoabacaxi levemente superior.

Os tratamentos de igual índice de seccionamento, ou seja, o 3 Gemas e o 3 Gemas + Benlate, demonstraram que a barreira quimica oferecida ao desenvolvimento do fungo apresentou efeito positivo, mesmo na avaliação realizada aos 70 dias após o plantio, o que certamente deve ter sido uma proteção essencial à brotação inicial das gemas, como pode ser notado na avaliação deste parâmetro no item 4.2. Estas afirmações atestam a eficiência do produto aplicado para impedir a infecção rápida por $C$. paradoxa, conforme as informações de HILTON et al. (1971), IAAPLANALSUCAR (1975) e SORDI 
(1983b) e, principalmente, no periodo imediatamente após o plantio, quando a possibilidade de danos letais às gemas em brotação é maior (BOYD \& GALLI, 1966).

As condições de temperatura e precipitação pluvial ocorrentes na época do ensaio de campo (Apêndice 1 e 2), possibilitaram situações nas quais a podridão-abacaxi costuma atacar os canaviais recém plantados, proporcionando condições mínimas exigidas para a normal brotação inicial das gemas da cana-de açúcar, conforme as afirmações de CLEMENTS (1940) e VAN DILLEWIJN (1948). Segundo as normais climatológicas do local do ensaio (Apêndice 1), percebe-se que o ano de 1983 possibilitou condições pós-plantio melhores que a média dos últimos 30 anos, permitindo a avaliação da influência das diferentes intensidade (\%) de podridão-abacaxi, com possibilidade de se estender os resultados obtidos para diferentes anos agrícolas.

O gradiente de intensidade (\%) de podridão-abacaxi provocado pelos tratamentos programados atingiu o objetivo de avaliação do comportamento da produção agrícola em diferentes niveis de ocorrência da doença, e que seriam essenciais ao desenvolvimento do estudo ora proposto (CHESTER, 1950; LARGE, 1966; FAO, 1971 e JAMES, 1974).

\subsection{Brotação inicial observada aos 50 dias após o plantio}

Pela avaliação estatística dos dados coletados chegou-se à conclusão que a brotação inicial foi significativamente diferente entre as variedades utilizadas ao nivel de $1 \%$ de probabilidade, com melhor resultado para a RB735275 seguida da RB725828 e por último da NA56-79. Entre os tratamentos aplicados, apenas o 3 Gemas diferiu significativamente dos demais apresentando-se com o menor número de brotação inicial aos 50 dias do plantio (Apêndice 3). 
Em experimentação conduzida também na Estação Experimental de Araras/SP, LEE (1984) observou igual número de brotos por metro entre plantios com toletes de 3 gemas e com canas inteiras, na variedade NA56-79, aos 42 dias do plantio realizado em setembro, portanto, com melhores condições de brotação inicial que os plantios tardios de abril/maio. Isto permite dizer que a podridão-abacaxi influenciou negativamente a brotação inicial do tratamento 3 Gemas no ensaio aqui analisado, em relação aos outros tratamentos que possibilitaram melhores brotações iniciais, mesmo nas condições climáticas adversas da época.

Tabela 3. Brotação inicial aos 50 dias após o plantio (número de brotos por 50 metros lineares de sulco).

\begin{tabular}{|c|c|c|c|c|c|c|c|c|c|c|}
\hline \multirow[t]{2}{*}{ Variedades } & \multicolumn{10}{|c|}{ Tratamentos } \\
\hline & \multicolumn{2}{|c|}{$3 G$} & \multicolumn{2}{|c|}{$3 G+B$} & \multicolumn{2}{|c|}{$6 \mathrm{G}$} & \multicolumn{2}{|c|}{ CTS } & \multicolumn{2}{|c|}{ CINT } \\
\hline NA56-79 & 69 & $\mathrm{Bb}$ & 85 & Bab & 123 & $B a b$ & 141 & Bab & 146 & $\mathrm{Aa}$ \\
\hline RB725828 & 86 & $A B b$ & 156 & Aab & 157 & ABab & 166 & $\mathrm{ABa}$ & 123 & $A a b$ \\
\hline RB735275 & 144 & $\mathrm{Aa}$ & 192 & $\mathrm{Aa}$ & 207 & $\mathrm{Aa}$ & 203 & $\mathrm{Aa}$ & 180 & $\mathrm{Aa}$ \\
\hline $\begin{array}{l}3 G=3 \text { Gemas; } \\
\text { Cana Inteira } \\
{ }_{\Delta(5)}\end{array}$ & & & & 5\%) T & $=75$ & & & & & \\
\hline Médias seguidas & letras & aiüs & iguais & ão d & tht & si par & & & & \\
\hline
\end{tabular}

Observou-se da avaliação da brotação inicial aos 50 dias do plantio, que as diferenças de comportamento varietal esperada com a escolha das três variedades estudadas realmente ocorreram no campo, propiciando boas condições para o desenvolvimento do objetivo pretendido neste trabalho. Entre os tratamentos, nota-se tendências de comportamento inferior do 3 Gemas, mostrando que o tratamento químico aplicado no tratamento 3 Gemas + Benlate surtiu efeito também na brotação inicial das variedades utilizadas, 
como já havia sido identificado na análise da intensidade (\%) de podridãoabacaxi (item 4.1).

\subsection{Número de perfilhos aos 110,200 e 310 dias após o plantio}

As variedades estudadas foram significativamente diferentes entre si, apenas para número de perfilhos contados aos 110 e 200 dias do plantio; quanto aos tratamentos, observou-se diferenças nas três leituras efetuadas após o plantio, ambos ao nível de $1 \%$ de probabilidade (Apêndice 4).

Dentre as variedades, observou-se para número de perfilhos aos 110 dias e 200 dias, o melhor índice apresentado pela RB735275 em relação às demais, que por sua vez não diferiram entre si.

Nos tratamentos aplicados, em relação ao número de perfilhos aos 110 dias e 200 dias, notou-se diferença significativa do 3 Gemas para os demais que foram superiores e não diferiram estatisticamente entre si; aos 310 dias os tratamentos 3 Gemas e 3 Gemas + Benlate foram inferiores aos demais que também não diferiram entre si (Apêndice 4).

As interaçōes variedades e tratamentos apontaram significância apenas nas leituras aos 310 dias do plantio, para número de perfilhos, indicando influência dos tratamentos sobre as variedades e vice versa (Apêndice 4).

Conforme se observa na Tabela 4, no tocante ao número de perfilhos aos 310 dias do plantio, as variedades estudadas não apresentaram diferenças significativas nos tratamentos 3 Gemas, 6 Gemas e Cana Inteira; nos tratamentos 3 Gemas + Benlate e o Corte no Terço Superior, apareceram diferenças apenas entre as variedades NA56-79 e RB725828, com pior comportamento da NA56-79, sendo a RB725828 equivalente à RB735275. Quanto aos tratamentos estudados, não se constatou diferenças significativas nas variedades NA56-79 e RB735275. Porém, na variedade RB725828 o 
tratamento 3 Gemas diferiu estatisticamente dos demais, apresentando-se com o menor indice de número de perfilhos aos 310 dias do plantio.

Tabela 4. Número de perfilhos observados aos 110, 200 e 310 dias após o plantio (Número de perfilhos por 50 metros lineares de sulco).

\begin{tabular}{|c|c|c|c|c|c|c|c|c|c|c|}
\hline \multirow[t]{2}{*}{ Variedades } & \multicolumn{10}{|c|}{ Tratamentos } \\
\hline & \multicolumn{2}{|c|}{$3 G$} & \multicolumn{2}{|c|}{$3 G+B$} & \multicolumn{2}{|c|}{$6 \mathrm{G}$} & \multicolumn{2}{|c|}{ CTS } & \multicolumn{2}{|c|}{ CINT } \\
\hline & \multicolumn{10}{|c|}{110 dias } \\
\hline NA56-79 & 196 & & 233 & & 306 & & 307 & & 344 & \\
\hline RB725828 & 153 & & 248 & & 248 & & 317 & & 227 & \\
\hline \multirow[t]{2}{*}{ RB735275 } & 260 & & 347 & & 375 & & 405 & & 407 & \\
\hline & \multicolumn{10}{|c|}{200 dias } \\
\hline NA56-79 & 628 & & 662 & & 797 & & 759 & & 748 & \\
\hline RB725828 & 461 & & 732 & & 761 & & 807 & & 672 & \\
\hline \multirow[t]{2}{*}{ RB735275 } & 792 & & 861 & & 823 & & 842 & & 851 & \\
\hline & \multicolumn{10}{|c|}{310 dias } \\
\hline NA56-79 & 538 & $\mathrm{Aa}$ & 529 & $\mathrm{Ba}$ & 588 & $\mathrm{Aa}$ & 536 & $\mathrm{Ba}$ & 567 & $\overline{A a}$ \\
\hline RB725828 & 479 & $A b$ & 593 & $\mathrm{Aa}$ & 622 & $\mathrm{Aa}$ & 609 & $\mathrm{Aa}$ & 622 & $\mathrm{Aa}$ \\
\hline RB735275 & 534 & $\mathrm{Aa}$ & 539 & $\mathrm{ABa}$ & 584 & $\mathrm{Aa}$ & 589 & $\mathrm{ABa}$ & 588 & $\mathrm{Aa}$ \\
\hline
\end{tabular}

$3 G=3$ Gemas; $3 G+B=3$ Gemas + Benlate; $6 G=6$ Gemas; $C T S=$ Corte no Terço Superior; CINT = Cana Inteira

$$
\begin{array}{rr}
\Delta(5 \%) V(T)=121(110 \text { dias }) & \Delta(5 \%) T(V)=150(110 \text { dias }) \\
156(200 \text { dias }) & 197(200 \text { dias }) \\
60(310 \text { dias }) & 67(310 \text { dias })
\end{array}
$$

Médias seguidas de letras maiúsculas iguais não diferem entre si para $V(T)$

Médias seguidas de letras minúsculas iguais não diferem entre si para T (V) 
Determinou-se que o número de perfilhos aos 310 dias do plantio foi semelhante entre os tratamentos estudados com apenas uma exceção, do tratamento 3 Gemas na variedade RB725828, com indice inferior aos demais.

Relacionando este parâmetro à avaliação da brotação inicial, pode-se admitir que houve compensação nos tratamentos que apresentaram menor brotação inicial aos 50 dias, com perfilhamento mais acentuado, equilibrando o número de perfilhos anotados aos 310 dias após o plantio. Também, pode se inferir que os tratamentos, mesmo aquele no qual não houve seccionamento do colmo plantado (cana inteira), não alteraram a população de perfilhos aos 310 dias do plantio.

Estes resultados estão em acordo com aqueles apresentados por LEE (1984), que não encontrou diferença em plantios com toletes de 3 gemas e plantios com cana inteira, na variedade NA56-79, em contagens realizadas aos 100, 172, 226 e 350 dias após o plantio feito em setembro, em Araras-SP.

A análise da população de perfilhos aos 310 dias será mais efetiva quando se avaliar a contagem de número de colmos industrializáveis colhidos item 4.6.

\subsection{Número de falhas de plantio}

Em relação ao número de falhas de plantio, observou-se diferenças estatísticas significativas entre tratamentos e as interaçōes variedades com tratamentos para número de falhas superiores a $80 \mathrm{~cm}$, ou seja, nas faixas de $81-120 \mathrm{~cm}$, maiores que $120 \mathrm{~cm}$ e também para o número total de falhas. Não se observaram diferenças significativas entre as variedades utilizadas (Apêndice 5). 
Tabela 5. Número de falhas entre touceiras em 50 metros lineares de sulco, nas classes de $50-80 \mathrm{~cm}, 81$ a $120 \mathrm{~cm}$ e maiores que $120 \mathrm{~cm}$ em cana planta. (Dados transformados para $\sqrt{x+1}$, exceto para número total de falhas).

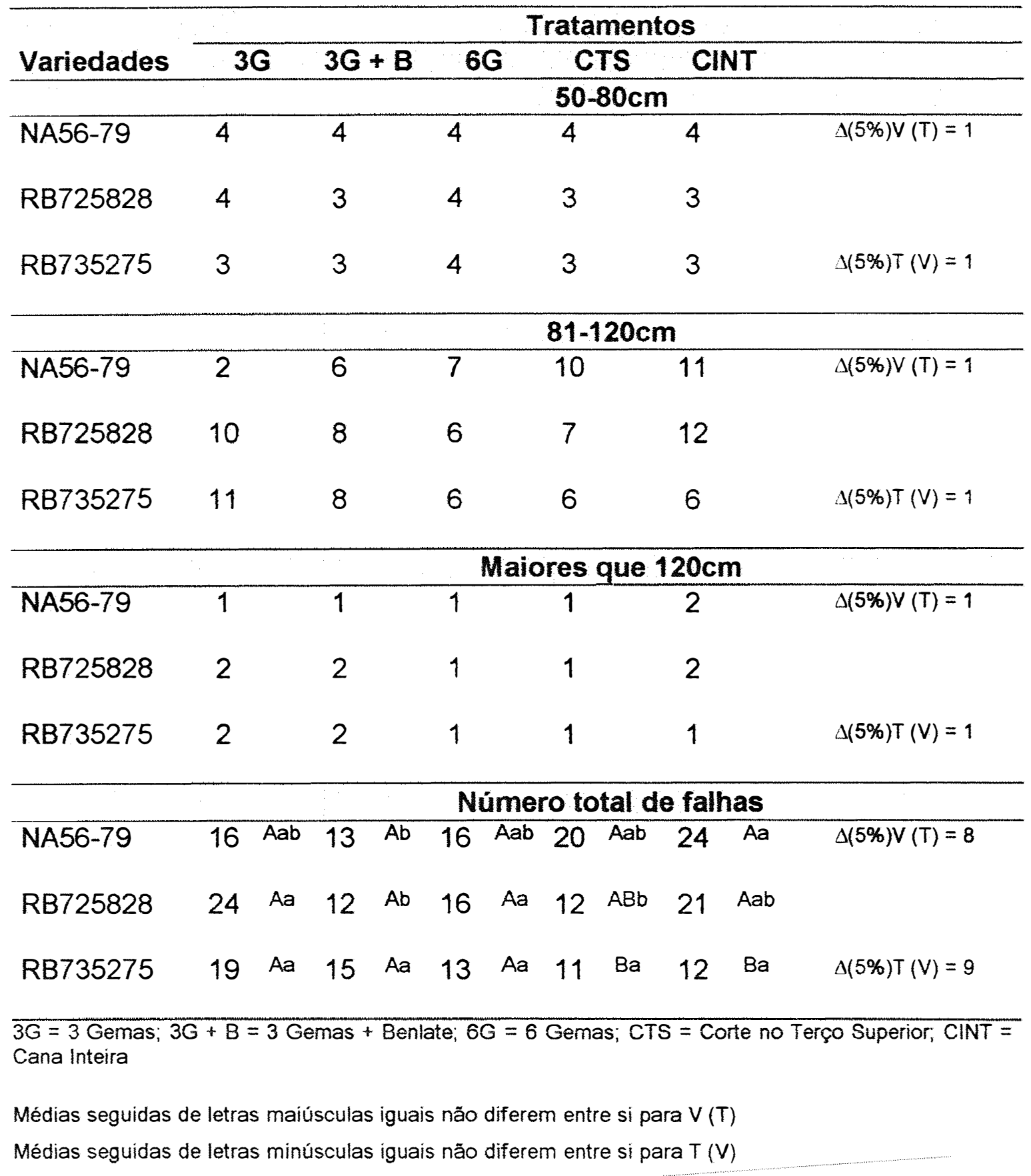


Nas falhas compreendidas entre 81 e $120 \mathrm{~cm}$ houve diferenças significativas entre as variedades, com a NA56-79 diferindo das demais no tratamento 3 Gemas e 3 Gemas + Benlate, sendo que NA56-79 apresentou-se com o menor número de falhas $(81-120 \mathrm{~cm})$. Inversamente porém, no tratamento Corte no Terço Superior, a NA56-79 apresentou maior número de falhas que as demais, assim como no tratamento Cana Inteira, onde NA56-79 e RB725828 igualmente apresentaram-se com maior número de falhas. Entre os tratamentos, o 3 Gemas apresentou menor número de falhas na variedade NA56-79 e, contrariamente, maior número de falhas na RB725828 e RB735275, superando nestas duas últimas variedades, o número de falhas ocorridas em tratamentos de maior seccionamento dos colmos (Tabela 5).

Quanto ao número de falhas maiores que $120 \mathrm{~cm}$, náo se observou diferenças significativas entre variedades e tratamentos (Tabela 5).

No que se refere ao número total de falhas maiores que $50 \mathrm{~cm}$, notouse diferenças significativas das variedades NA56-79 e RB725828 com a RB735275 no tratamento Corte no Terço Superior, onde as primeiras apresentaram maior número. No tratamento Cana Inteira, também as variedades NA56-79 e RB725828 foram as que apresentaram maior número de falhas, e diferentes significativamente da RB735275. Entre os tratamentos aplicados não se apresentaram diferenças significativas nas variedades NA5679 e RB735275; na variedade RB725828, o tratamento 3 Gemas apresentou-se com maior número total de falhas que os tratamentos 3 Gemas + Benlate e Corte no Terço Superior, sendo que os demais tratamentos não diferiram significativamente entre si (Tabela 5).

A análise dos dados coletados para número de falhas entre 81 e $120 \mathrm{~cm}$ permitiu avaliar que a variedade NA56-79 apresentou melhor comportamento nos tratamentos de maior intensidade de seccionamento dos colmos ( $3 G$ e $3 G$ + B) e pior comportamento nos tratamentos de menor seccionamento dos colmos. As variedades RB725828 e RB735275 tiveram melhor comportamento 
nos tratamentos com seccionamento intermediário dos colmos ( $6 \mathrm{G}$ e CTS), com a RB735275 estendendo este melhor comportamento também ao tratamento Cana Inteira. Pode-se verificar que o comportamento das variedades e dos tratamentos foram bastante erráticos, o que no caso do presente estudo tornase interessante e comprova o acerto na escolha das variedades com capacidades diferentes de reação diante dos tratamentos aplicados e das condiçōes reinantes durante o transcorrer das avaliações de campo. Esta mesma análise e observações podem ser estendidas ao conjunto do número total de falhas de plantio observadas e superiores a $50 \mathrm{~cm}$.

\subsection{Comprimento total das falhas de plantio}

No tocante ao comprimento das falhas observadas, houve diferenças significativas entre as variedades estudadas apenas em relação ao comprimento total destas falhas. Entre tratamentos e a interação variedades $x$ tratamentos apareceram diferenças significativas apenas nas falhas superiores a $50-80 \mathrm{~cm}$, ou seja, falhas de $81-120 \mathrm{~cm}$ e maiores que $120 \mathrm{~cm}$, e no comprimento total das falhas existentes (Apêndice 6).

Como a qualidade do plantio é função do comprimento total das falhas observadas, notou-se que na variedade NA56-79 o tratamento Cana Inteira igualou-se estatisticamente ao Corte no Terço Superior e ambos foram significativamente diferentes dos demais, apresentando os maiores comprimentos totais de falhas. Na variedade RB725828 os tratamentos 3 Gemas e Cana Inteira foram estatisticamente iguais e diferentes dos demais, que se apresentaram com menores comprimentos totais de falhas; na variedade RB735275, os tratamentos 3 Gemas, 3 Gemas + Benlate, 6 Gemas e Cana Inteira não apresentaram diferenças estatisticas entre si, e diferiram apenas ao tratamento Corte no Terço Superior, o qual apresentou o menor 
comprimento total de falhas de plantio, conforme pode ser observado na Tabela 6.

Tabela 6. Comprimento das falhas maiores que $50 \mathrm{~cm}$, em 50 metros lineares de sulco, entre touceiras formadas, nas classes de $50-80 \mathrm{~cm}$, $81-120 \mathrm{~cm}$ e maiores que $120 \mathrm{~cm}$, em cana planta (Dados transformados para $\sqrt{x+1}$, exceto para comprimento total de falhas).

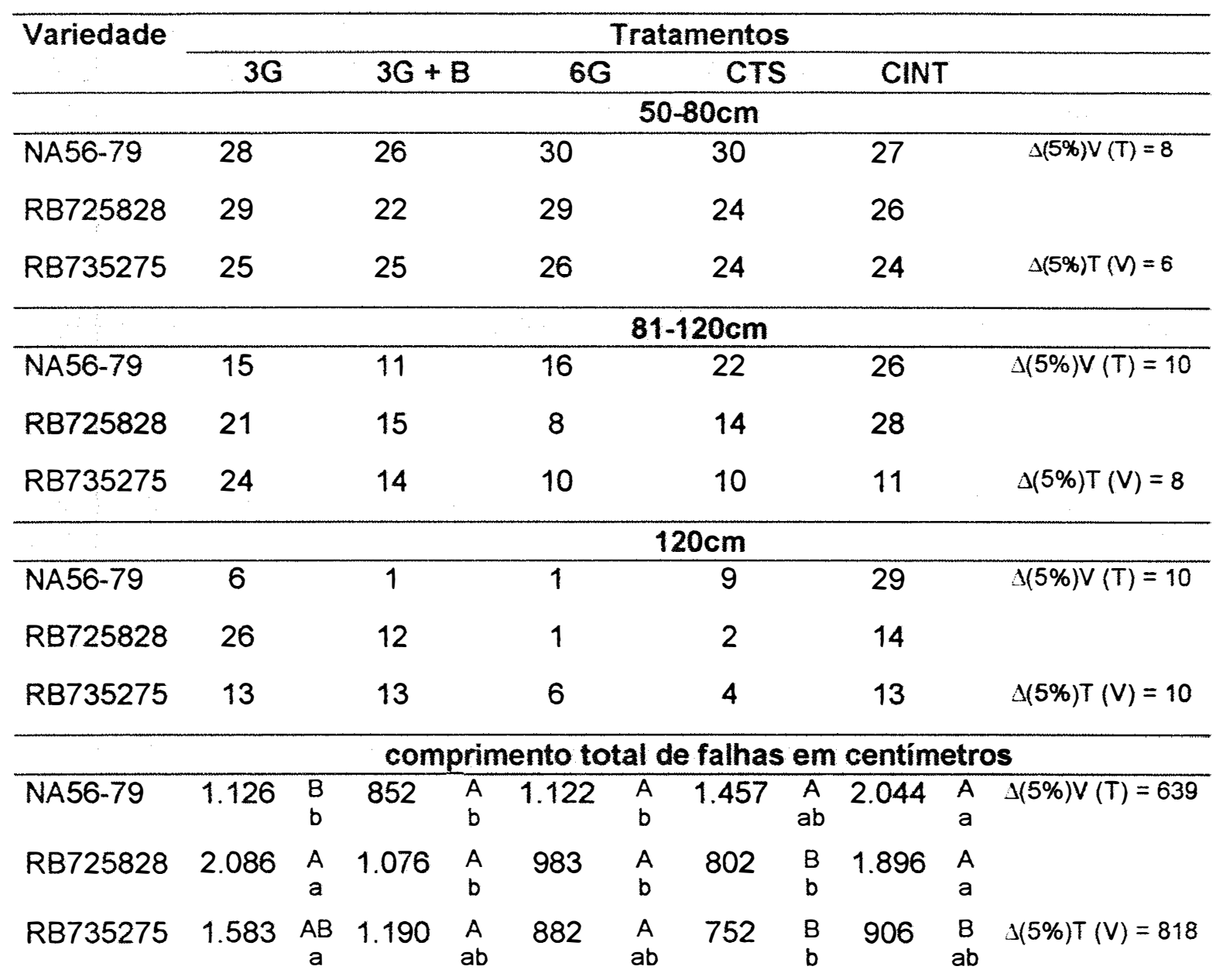

$3 G=3$ Gemas; $3 G+B=3$ Gemas + Benlate; $6 G=6$ Gemas; CTS = Corte no Terço Superior; CINT $=$ Cana Inteira

Médias seguidas de letras maiúsculas iguais não diferem entre si para $V(T)$ Médias seguidas de letras minúsculas iguais não diferem entre si para $T(V)$ 
As variedades utilizadas apresentaram comportamento semelhante nos tratamentos 3 Gemas + Benlate e 6 Gemas; no 3 Gemas a RB725828 e a RB735275 foram estatisticamente iguais, e a NA56-79 apresentou menor comprimento total de falhas; no Corte no Terço Superior, porém, a NA56-79 apresentou maior comprimento total de falhas diferindo significativamente das demais, que se igualaram. No tratamento Cana Inteira, NA56-79 e RB725828 apresentaram o mesmo comportamento, ambas com maior comprimento total de falhas que a RB735275.

Observa-se, também, quanto ao parâmetro comprimento total de falhas, o comportamento alternado das variedades nos tratamentos e vice-versa. Tal detalhe caracteriza a representatividade diferencial das variedades e tratamentos programados, na presença da doença causada por C. paradoxa, oferecendo o suporte necessário para o estudo genérico da cultura da cana-deaçúcar diante dos objetivos propostos neste trabalho.

A Tabela 7, a seguir, mostra a ocorrência de comprimento total de falhas maiores que $50 \mathrm{~cm}$, em porcentagem, conforme metodologia desenvolvida por STOLF (1986).

Tabela 7. Ocorrência porcentual de falhas (F\%) superiores a $50 \mathrm{~cm}$, e classificação segundo STOLF (1986).

\begin{tabular}{|c|c|c|c|c|c|}
\hline \multirow[t]{2}{*}{ Variedades } & \multicolumn{5}{|c|}{ Tratamentos (F\%) } \\
\hline & $3 G$ & $3 G+B$ & $6 \mathrm{G}$ & CTS & CINT \\
\hline NA56-79 & $23 M$ & $17 \mathrm{~B}$ & $22 M$ & $29 M$ & $41 R$ \\
\hline RB725828 & $42 \mathrm{R}$ & $22 M$ & 208 & 16 в & $38 \mathrm{R}$ \\
\hline RB735275 & $32 \mathrm{~m}$ & $24 M$ & 18 в & $15 \mathrm{~B}$ & 18 в \\
\hline Média por Tratamento & $32 M$ & $21 \mathrm{M}$ & $20 \mathrm{~B}$ & $20 \mathrm{~B}$ & $32 \mathrm{M}$ \\
\hline $\begin{array}{l}3 G=3 \text { Gemas; } 3 G+B=3 \mathrm{Ge} \\
\text { cana Inteira }\end{array}$ & & & & & \\
\hline
\end{tabular}


A qualidade do plantio foi ruim apenas na NA56-79 (Cana Inteira), e na RB725828 (3 Gemas e Cana Inteira). Nos demais tratamentos em todas as variedades utilizadas, o plantio foi considerado como médio a bom.

Em razão das características do ensaio projetado seria normal a observação contrastante com resultados de outros trabalhos, normalmente conduzidos em situações que favoreçam o rápido desenvolvimento da brotação inicial e desenvolvimento das plantas de cana-de-açúcar. Mesmo assim, o trabalho de BRITO (1988) apresentou qualidade de plantio média nos sistemas de plantio de meia cana e cana inteira, bastante próximos dos observados na média dos tratamentos propostos no presente ensaio de campo. Já LEE (1984) encontrou excelente qualidade de plantio com canas inteiras, com falhas de $10 \%$ apenas, porém, em plantio realizado em setembro, quando as condições climáticas favorecem o desenvolvimento da brotação inicial da cana-de-açúcar.

A avaliação de qualidade do plantio segundo a \% de falhas observadas, também define o comportamento diferencial das variedades, conforme sua reação à presença de $C$. paradoxa no solo e suas características ante o nivel de seccionamento aplicado, contribuindo para a avaliação conjunta dos tratamentos. $\mathrm{Na}$ análise da média de Falhas (\%) por tratamento, nas variedades, nota-se tendência de qualidade de plantio igual dos tratamentos 3 Gemas e Cana Inteira, sendo ambos inferiores aos demais tratamentos que foram semelhantes. A aparente contradição para maior indice de falhas no tratamento 3 Gemas, levando-o a se igualar ao tratamento Cana Inteira, tem na presença da maior incidência de podridão-abacaxi quando o seccionamento foi intenso (3 Gemas) a explicação adequada, observando-se que o tratamento semelhante, mas com introdução de proteção quimica apresentou-se superior. Quanto ao Cana Inteira, nas quantidades de gemas colocadas no plantio (12 gemas por metro linear), tem-se que a dominância apical contribuiu decisivamente para a referida qualidade de plantio, o que deve ser minimizado se considerarmos que os plantios comuns, e notadamente aqueles mais 
atrasados, são efetuados com densidades maiores, chegando a dobrar o número de gemas por metro linear utilizado neste ensaio de campo.

\subsection{Número de colmos industrializáveis}

A análise de variância para número de colmos industrializáveis anotados à época da colheita, mostraram diferenças entre variedades, tratamentos $e$ para a interação variedades $\times$ tratamentos, a nível de $1 \%$ de probabilidade, em cana-planta. Para cana-soca, variedades e tratamentos apresentaram diferenças significativas a $5 \%$ de probabilidade, enquanto a interação variedades $x$ tratamentos apresentou-se como não significativa (Apêndice 8).

Em cana-planta, as variedades RB725828 e RB735275 apresentaram comportamento semelhante e superiores à NA56-79 para número de colmos industrializáveis; em cana-soca a mesma tendência foi verificada, com recuperação da NA56-79 que apresentou-se semelhante à RB725828 (Apêndice 8).

Para os tratamentos estudados, em cana-planta, o Cana Inteira, o 6 Gemas e o Corte no Terço Superior apresentaram-se semelhantes, e com melhores resultados para número de colmos industrializáveis, diferindo dos tratamentos 3 Gemas + Benlate e 3 Gemas, que por sua vez também diferiram entre si. Em cana soca não houve diferenças significativas entre tratamentos (Apêndice 8).

$\mathrm{Na}$ Tabela 8 , observa-se os resultados da interação variedades $x$ tratamentos em cana-planta; esta Interação não foi significativa em cana-soca. Todos os tratamentos apresentaram comportamento semelhante na NA56-79; na RB725828 apenas o tratamento 3 Gemas foi inferior aos demais, o mesmo ocorrendo na RB735275, onde, a rigor, o 3 Gemas diferiu estatisticamente apenas do Cana Inteira. Para os tratamentos notou-se que o Cana Inteira e o Corte no Terço Superior tiveram resultados semelhantes e superiores nas 
variedades RB725828 e RB735275; no tratamento 6 Gemas as três variedades apresentaram resultado semelhante, enquanto no 3 Gemas + Benlate a RB725828 apresentou-se superior e no 3 Gemas apresentou-se inferior em relação às duas outras variedades.

Tabela 8. Número de colmos industrializáveis - (número de colmos por 50 metros lineares de sulco), em cana-planta e cana-soca.

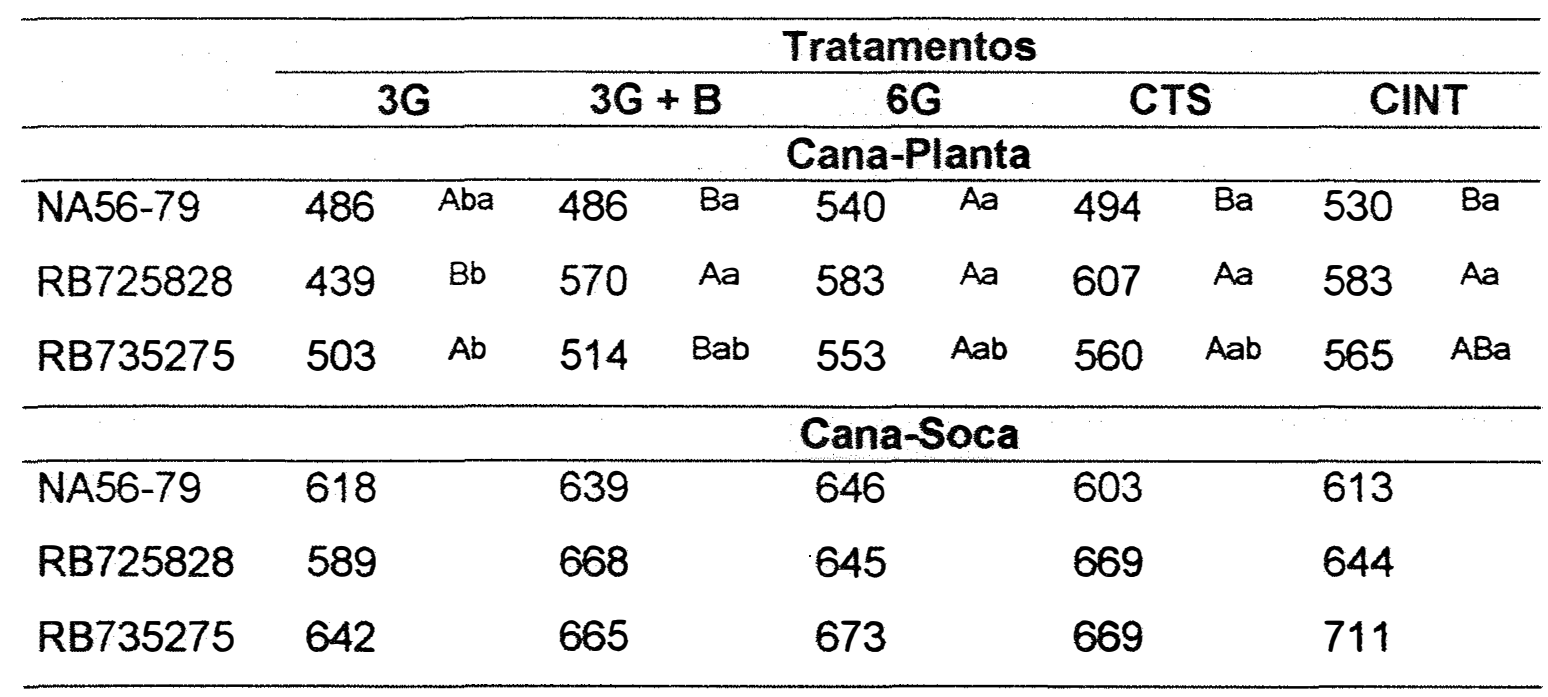

$3 G=3$ Gemas; $3 G+B=3$ Gemas + Benlate; $6 G=6$ Gemas; $C T S=$ Corte no Terço Superior; CINT = Cana Inteira

Cana-planta $-\Delta(5 \%) V(T)=51 ; \quad \Delta(5 \%) T(V)=61$

Cana-soca - V x T não significativa

Médias seguidas de letras maiúsculas iguais não diferem entre si para $V(T)$

Médias seguidas de letras minúsculas iguais não diferem entre si para $T(V)$

Observação evidente se faz na comparação dos tratamentos em cada variedade, onde apenas o 3 Gemas diferiu significativamente dos demais com resultado inferior em número de colmos industrializáveis, com uma única exceção na variedade NA56-79, onde todos os tratamentos foram 
estatisticamente iguais. Isto demonstra que o tratamento 3 Gemas, sem a proteção química do Benlate, foi certamente prejudicado pela ação da podridão-abacaxi presente, da mesma forma como já havia sido observado quando da análise do parâmetro Brotação Inicial aos 50 dias do plantio (item 4.2.). Também em relação à análise do parâmetro número de perfilhos aos 310 dias do plantio (item 4.3), notou-se que houve diminuição do número de perfilhos para colmos industrializáveis obtidos na ocasiāo da colheita (495 dias após o plantio), embora mantendo as tendências verificadas quando desta contagem efetuada aos 310 dias. Estes dados estão em acordo com as conclusões de KANWAR et al. (1975), YANG et al. (1981), LEE (1984) e BRITO (1988), que não encontraram diferenças no número de colmos colhidos por hectare quando se alterou o indice de seccionamento do colmo plantado.

Nota-se, com a semelhança do número de colmos industrializáveis em todos os tratamentos aplicados em diferentes variedades (exceção do tratamento 3 Gemas na RB725828), a grande capacidade de compensação da cultura da cana-de-açúcar, ocupando o espaço disponivel principalmente na linha de plantio. Isto está evidente quando se compara o indice de falhas observadas nas parcelas experimentais (Tabela 7), ressaltando que parcelas com $17 \%$ e $41 \%$ de falhas apresentaram semelhante população de colmos finais (variedade NA56-79), ou, da mesma forma falhas de $16 \%$ e $38 \%$ na variedade $R B 725828$, e $15 \%$ e $32 \%$ na variedade $R B 735275$.

\subsection{Rendimento agricola (t/ha)}

A análise estatistica efetuada nos dados de rendimento agricola das variedades e tratamentos analisados mostram que, tanto em cana planta como em cana soca, houve diferenças significativas para variedades e para tratamentos, a nivel de $1 \%$ de probabilidade. $\mathrm{Na}$ interação variedades e 
tratamentos as diferenças estatísticas situaram-se ao nivel de $5 \%$ de probabilidade (Apêndice 10).

Para o rendimento agricola médio das variedades (Apêndice 10), observou-se o comportamento idêntico das tendências entre elas, com a RB735275 apresentando o maior rendimento, seguida da NA56-79 e por último da RB725828. Em termos estatísticos, para cana planta, as três variedades diferiram significativamente entre si, e em cana soca a RB735275 foi superior às demais, que não apresentaram diferenças significativas entre si.

Entre os tratamentos analisados, o Cana Inteira, o Corte no Terço Superior e o 6 Gemas não diferiram significativamente entre si e foram superiores aos demais, tanto em cana planta como em cana soca. Obviamente para planta e soca, os piores indices de rendimento agricola foram para os tratamentos 3 Gemas e 3 Gemas + Benlate (Apêndice 10).

A Tabela 9 apresenta as relações entre as variedades e os tratamentos analisados. Em cana-planta, na variedade NA56-79, o Cana Inteira, o Corte no Terço Superior e o 6 Gemas foram iguais estatisticamente, sendo superiores e diferentes do 3 Gemas e 3 Gemas + Benlate; na RB725828 apenas o 3 Gemas foi inferior e significativamente diferente dos demais; na RB735275, os tratamentos de maior rendimento agricola foram o Cana Inteira e o Corte no Terço Superior, iguais estatisticamente entre si, com tendência de serem acompanhados pelo 6 Gemas.

Em cana-soca, observa-se a mesma orientação comentada para canaplanta, para a análise do rendimento agricola (Tabelas 9 e 10), com uma relevante alteração: os tratamentos com intenso seccionamento do colmo no plantio, apresentaram melhor comportamento em termos de rendimento agricola, aproximando-se dos demais. Para a NA56-79, os tratamentos foram rigorosamente iguais estatisticamente; na RB725828 apenas o 3 Gemas diferiu dos demais, e com menor produção; na RB735275, o 3 Gemas e 3 Gemas + 
Benlate foram os de menores produções, diferindo estatisticamente, a rigor, apenas do tratamento Cana Inteira.

Tabela 9. Rendimento agricola (peso médio das parcelas - kg ) em canaplanta e cana-soca.

\begin{tabular}{|c|c|c|c|c|c|c|c|c|c|c|}
\hline \multirow{4}{*}{$\begin{array}{l}\text { Variedades } \\
\text { NA56-79 }\end{array}$} & \multicolumn{10}{|c|}{ Tratamentos } \\
\hline & \multicolumn{2}{|c|}{$3 G$} & \multicolumn{2}{|c|}{$3 G+B$} & \multicolumn{2}{|c|}{$6 \mathbf{G}$} & \multicolumn{2}{|c|}{ CTS } & \multicolumn{2}{|c|}{ CINT } \\
\hline & \multicolumn{10}{|c|}{ Cana-Planta } \\
\hline & 675 & $\mathrm{Bb}$ & 673 & $\mathrm{Bb}$ & 806 & $\mathrm{Ba}$ & 751 & $\mathrm{Bab}$ & 828 & $\mathrm{Ba}$ \\
\hline RB725828 & 528 & $\mathrm{Cb}$ & 703 & $\mathrm{Ba}$ & 730 & $\mathrm{Ba}$ & 771 & $\mathrm{Ba}$ & 760 & $\mathrm{Ba}$ \\
\hline RB735275 & 836 & Ac & 821 & $A C$ & 920 & $A b c$ & 980 & Aab & 1040 & $\mathrm{Aa}$ \\
\hline \multicolumn{5}{|c|}{$\Delta(5 \%) V(T)=94$} & \multicolumn{6}{|c|}{$\Delta(5 \%) T(V)=116$} \\
\hline & \multicolumn{10}{|c|}{ Cana-Soca } \\
\hline NA56-79 & 854 & $\mathrm{Ba}$ & 863 & $\mathrm{Aa}$ & 922 & $\mathrm{Ba}$ & 843 & $\mathrm{Ba}$ & 878 & $\mathrm{Ba}$ \\
\hline RB725828 & 749 & $\mathrm{Cb}$ & 863 & $\mathrm{Aa}$ & 871 & $\mathrm{Ba}$ & 91 & $\mathrm{Ba}$ & 891 & $\mathrm{Ba}$ \\
\hline RB735275 & 961 & $A b$ & 928 & $A b$ & 1020 & Aab & 1026 & Aab & 1095 & $\mathrm{Aa}$ \\
\hline \multicolumn{5}{|c|}{$\Delta(5 \%) V(T)=97$} & \multicolumn{6}{|c|}{$\Delta(5 \%) T\langle V\rangle=110$} \\
\hline
\end{tabular}

$3 G=3$ Gemas; $3 G+B=3$ Gemas + Benlate; $6 G=6$ Gemas; $C T S=$ Corte no Terço Superior; CINT $=$ Cana Inteira

Médias seguidas de letras maiúsculas iguais não diferem entre si para $V(T)$

Médias seguidas de letras minúsculas iguais não diferem entre si para T (V) 
Tabela 10. Rendimento agricola em toneladas por hectare (t/ha) em canaplanta e cana-soca.

\begin{tabular}{lccc}
\hline & \multicolumn{3}{c}{ Rendimento agricola (t/ha) } \\
\cline { 2 - 4 } & NA56-79 & RB725828 & RB735275 \\
\hline \multicolumn{4}{c}{ Cana-Planta } \\
\hline 3G & 96,4 & 75,4 & 119,5 \\
6G B & 96,1 & 100,4 & 117,3 \\
CTS & 115,2 & 104,3 & 131,4 \\
CINT & 107,3 & 110,2 & 140,0 \\
\hline \multicolumn{4}{c}{ Cana-Soca } \\
3G & 118,2 & 108,6 & 148,6 \\
3G + B & 122,0 & 123,3 & 137,3 \\
6G & 123,3 & 124,4 & 132,6 \\
CTS & 131,7 & 130,1 & 145,7 \\
CINT & 120,4 & 127,3 & 146,5 \\
\hline
\end{tabular}

$3 G=3$ Gemas; $3 G+B=3$ Gemas + Benlate; $6 G=6$ Gemas; $C T S=$ Corte no Terço Superior; CINT = Cana Inteira

Esta análise está coerente com os dados de número de colmos industrializáveis colhidos (item 4.6), onde a interação variedades e tratamentos não foi significativa em cana-soca. Em cana-planta, porém, a população de colmos industrializáveis semelhantes, não foi suficiente para apresentar rendimentos agricolas também semelhantes. Este fato, conforme analisado no item 4.1- Intensidade (\%) de ocorrência da podridão-abacaxi nos diferentes tratamentos, comprova que niveis mais altos de infecção em tratamentos com maior intensidade de seccionamento dos colmos, interferiram no desenvolvimento dos colmos produzidos. Isto está bastante evidente na NA5679; na RB725828 houve inclusive interferência na população de colmos produzidos, o que na RB735275 ocorreu também, embora com menor influência no resultado final de colmos industrializáveis ou rendimento agrícola.

A associação da intensidade (\%) de ocorrência de podridão-abacaxi com 0 indice de falhas observadas em cada tratamento programado (Tabela 7), 
permite a observação de que a infestação de $C$. paradoxa provocou niveis de falhas consideráveis no tratamento 3 Gemas (exceção da NA56-79), comparáveis aos niveis obtidos no tratamento Cana Inteira, pelo índice médio de Falhas $(\%)$ por tratamento. Apesar disso, o rendimento agricola foi superior no tratamento Cana Inteira comparado ao 3 Gemas em todas as variedades, ressaltando outra vez, a interferência prejudicial da Podridão Abacaxi no desenvolvimento dos colmos, cuja compensação havida no tratamento Cana Inteira não foi obtida no 3 Gemas.

Quanto ao tratamento $3 G$ + Benlate, conclui-se que a proteção química ofereceu condições para a brotação inicial, semelhante aos tratamentos de maior seccionamento dos colmos plantados, porém, tal proteção não foi suficiente para evitar a interferência da podridão-abacaxi no desenvolvimento dos colmos, e consequentemente no rendimento agricola. Quando da avaliação da intensidade (\%) de podridão-abacaxi aos 70 dias do plantio (item 4.1.), já se notava que o fungo incidia sobre a maior parte do tecido dos toletes, embora tivesse proporcionado boa brotação inicial das gemas, permitindo concluir que o fungo $C$. paradoxa exerce ação fitotóxica, prejudicando o desenvolvimento dos colmos que conseguiram sobreviver à fase inicial do ataque, conforme indicavam os comentários de WISMER \& BAILEY (1989), BYTHER \& STEINER (1970) e SORDI (1983a).

Os dados obtidos de rendimento agrícola para os diversos sistemas de plantio utilizados estão de acordo com as informações obtidas de outros autores como ARCENEAUX (1948), KANWAR et alii (1975), LONDSDALE (1977), LEE (1984) e BRITO (1988). 


\subsection{Ajuste de dados para exprimir as relaçōes da intensidade (\%) de ocorrência de podridão-abacaxi com o rendimento agricola e com as perdas de produção agrícola da cana-de-açúcar}

A Tabela 11 apresenta para cada variedade e tratamento estudados, os dados médios de intensidade (\%) de podridão-abacaxi, os rendimentos agricolas (tha) em cana-planta e soca, e os cálculos de perdas na produção agrícola também em t/ha. Para o cálculo de perdas partiu-se do pressuposto que $\circ$ tratamento de menor intensidade (\%) de doença, conseguido pela aplicação das técnicas preconizadas para provocar variação dos niveis de infecção no campo, segundo informações definidas por CHESTER (1950), LARGE (1966), JAMES (1974), JAMES \& TENG (1979), SHANE \& TENG (1987) e SAH \& MACKENZIE (1987), seria considerado como perda nula ou igual a zero.

A partir dos dados da Tabela 11, analisou-se estatisticamente a probabilidade de se representar os dados através de regressão. As análises de variância estão no Apêndice 11, onde se nota que em cana-planta, o valor do teste $F$ para a regressão foi significativo a nivel de $1 \%$ para as três variedades utilizadas. Em cana-soca houve resultado significativo de $F$ apenas na variedade $R B 735275$.

estudo de representação funcional dos dados da Tabela 11 num modelo geral $y=f(x)$, onde " $x$ " seria a variável independente quantidade de doença, no caso intensidade (\%) de podridão-abacaxi aos 70 dias do plantio, e "y" seria o rendimento agricola (t/ha), define a aplicação do Modelo do Ponto Crítico definido por JAMES (1974). A Tabela 12 mostra para as três variedades utilizadas, o modelo matemático empírico representado pelas equações de regressão linear e quadrática, com os respectivos coeficientes de determinação $r^{2}$. 


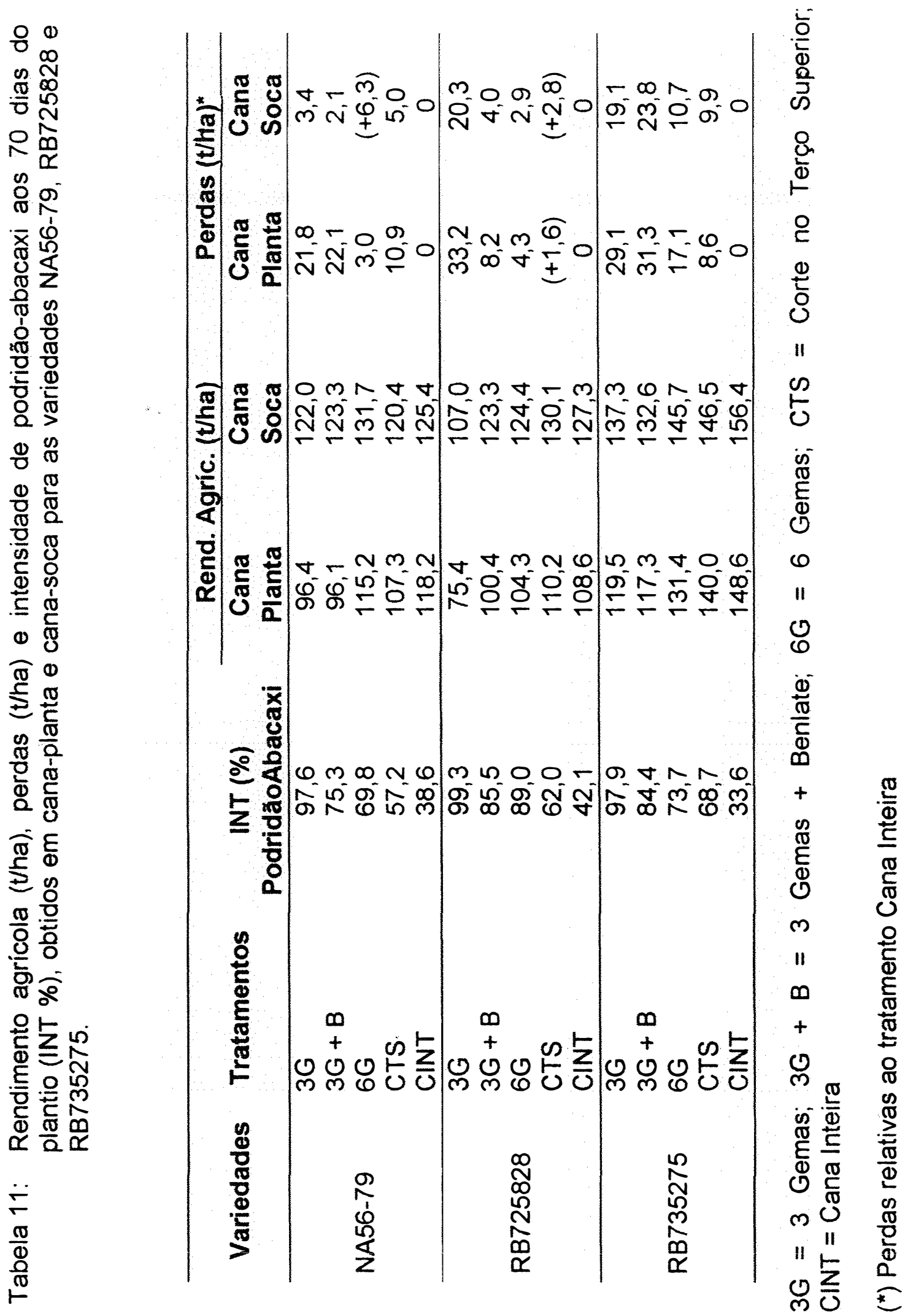


Os valores apresentados da representatividade da equação calculada, através do coeficiente de determinação $r^{2}$, permite observar um ajuste variável da regressão nas três variedades, o que representa na prática, as diferentes respostas varietais em termos de produção agricola, frente ao ataque de $C$. paradoxa nos toletes do plantio. Esta reação diferencial acusada pelas variedades utilizadas, e comentada anteriormente na análise dos fatores de formação do rendimento agricola, permite sustentação para a elaboração de um modelo matemático único para a cultura da cana-de-açúcar, a partir da representação cultural média entre as três variedades, dos parâmetros $x$ e y da função básica $y=f(x)$.

Tabela 12. Estudo de regressão para a correspondência dos dados do rendimento agrícola (tha) e intensidade (\%) de podridão-abacaxi aos 70 dias do plantio.

\begin{tabular}{|c|c|c|c|}
\hline \multirow[b]{2}{*}{ Variedades } & \multicolumn{3}{|c|}{$\begin{array}{l}\text { Ajuste dos dados do rendimento (t/ha) e } \\
\text { intensidade }(\%) \text { de podridão-abacaxi }\end{array}$} \\
\hline & Grau & Equação & $r^{2}$ \\
\hline & \multicolumn{3}{|c|}{ Cana-Planta } \\
\hline NA56-79 & $\begin{array}{l}\mathrm{RL} \\
\mathrm{RQ}\end{array}$ & $\begin{array}{l}y=-0,37 x+131,82 \\
y=0,0008 x^{2}-0,48 x+135,27\end{array}$ & $\begin{array}{l}0.625 \\
0,627\end{array}$ \\
\hline RB725828 & $\begin{array}{l}\mathrm{RL} \\
\mathrm{RQ}\end{array}$ & $\begin{array}{l}y=-0,44 x+133,27 \\
y=-0,02 x^{2}+2,87 x+27,85\end{array}$ & $\begin{array}{l}0,525 \\
0,859\end{array}$ \\
\hline \multirow[t]{2}{*}{ RB735275 } & $\begin{array}{l}\mathrm{RL} \\
\mathrm{RQ}\end{array}$ & $\begin{array}{l}y=-0,51 x+167,68 \\
y=-0,0031 x^{2}-0,1033 x+ \\
156,39\end{array}$ & $\begin{array}{l}0,836 \\
0,850\end{array}$ \\
\hline & \multicolumn{3}{|c|}{ Cana-Soca } \\
\hline NA56-79 & $\begin{array}{l}\mathrm{RL} \\
\mathrm{RQ}\end{array}$ & $\begin{array}{l}y=-0,0271 x+126,4 \\
y=-0,026 x^{2}+0,32 x+115,54\end{array}$ & $\begin{array}{l}0,02 \\
0,09\end{array}$ \\
\hline RB725828 & $\begin{array}{l}\mathrm{RL} \\
\mathrm{RQ}\end{array}$ & $\begin{array}{l}y=-0,28 x+143,55 \\
y=-0,0164 x^{2}+2,01 x+70,55\end{array}$ & $\begin{array}{l}0,515 \\
0,909\end{array}$ \\
\hline RB735275 & $\begin{array}{l}\mathrm{RL} \\
\mathrm{RQ}\end{array}$ & $\begin{array}{l}y=-0,35 x+168,4 \\
y=0,0002 x^{2}-0,3644 x+ \\
168,95\end{array}$ & $\begin{array}{l}0,814 \\
0,814\end{array}$ \\
\hline
\end{tabular}


A Tabela 13 apresenta os dados calculados de intensidade (\%) de podridão-abacaxi, rendimento agricola (t/ha) e perdas de produção agrícola (t/ha), construida a partir dos dados obtidos para cada variedade utilizada na avaliação.

Tabela 13. Rendimento agricola (t/ha), perdas (t/ha) e intensidade (\%) de podridão-abacaxi aos 70 dias do plantio (INT. \%), obtidos para cana-planta e cana-soca.

\begin{tabular}{llccc}
\hline Variedades & Tratamentos & $\begin{array}{c}\text { INT. (\%) } \\
\text { Pod.- Abacaxi }\end{array}$ & $\begin{array}{c}\text { Rendimento } \\
\text { agricola (t/ha) }\end{array}$ & $\begin{array}{c}\text { Perdas } \\
\text { (t/ha) }\end{array}$ \\
\hline \multirow{5}{*}{ Cana-planta } & 3G & 98,3 & 97,1 & 28,0 \\
& GG + B & 81,7 & 104,6 & 20,6 \\
& CTS & 77,5 & 117,0 & 8,2 \\
& CINT & 62,6 & 119,2 & 6,0 \\
Cana-soca & 38,1 & 125,2 & 0 \\
\hline & GG & & 122,1 & 14,3 \\
& GG + B & & 126,4 & 10,0 \\
& CTS & & 133,9 & 2,4 \\
& CINT & & 132,3 & 4,0 \\
\hline
\end{tabular}

$3 G=3$ Gemas; $3 G+B=3$ Gemas + Benlate; $6 G=6$ Gemas; $C T S=$ Corte no Terço Superior; CINT = Cana Inteira

Da mesma forma como procedido em relação às variedades individualmente, efetuou-se o ajuste desses dados num modelo matemático, obtendo-se as equações de regressão e respectivos coeficientes de determinação $r^{2}$ que estão apresentados na Tabela 14. 
Tabela 14. Equações de regressão para os dados conjuntos de rendimento agricola (t/ha) das variedades utilizadas, em cana-planta e canasoca, e as respectivas intensidades (\%) de podridão-abacaxi aos 70 dias do plantio.

\begin{tabular}{|c|c|c|c|}
\hline & \multicolumn{3}{|c|}{$\begin{array}{l}\text { Ajuste dos dados de rendimento (t/ha) e } \\
\text { intensidade (\%) de podridão-abacaxi }\end{array}$} \\
\hline & Grau & Equação & $r^{2}$ \\
\hline \multirow[t]{2}{*}{ Cana-planta } & $\mathrm{RL}$ & $y=-0,46 x+145,78$ & $0,836^{\star \star *}$ \\
\hline & $R Q$ & $y=-0,007 x^{2}+0,48 x+117,23$ & 0,909 \\
\hline \multirow[t]{2}{*}{ Cana-soca } & $\mathrm{RL}$ & $y=-0,22 x+146,25$ & $0,753^{\star \star}$ \\
\hline & $R Q$ & $y=-0,0038 x^{2}+0,29 x+130,58$ & 0,837 \\
\hline
\end{tabular}

INT \% = Intensidade de ocorrència de podridão-abacaxi aos 70 dias do plantio.

RL - Regressão linear $R Q$ - Regressão quadrática

Os ajustes desenvolvidos com os dados de colheita da cana-planta e da cana-soca, refletem a influência da podridão-abacaxi no rendimento agrícola da cana-de-açúcar, nestas duas colheitas sucessivas. Em cana-planta, a análise de variância para regressão, através do teste $F$, apresentou significância ao nivel de $1 \%$ de probabilidade para todas as variedades utilizadas (Apêndice 11). Em cana-soca, a análise de variância para regressão não se mostrou significativa na variedade NA56-79; na RB725828 e na RB735275, o teste $F$ foi significativo a nivel de $5 \%$ e $1 \%$ de probabilidade, respectivamente (Apêndice 11).

A equação de regressão que representa as relações entre os diversos níveis de infecção de podridão-abacaxi, e os rendimentos agrícolas (t/ha), teve excelente ajuste com os dados de cana-planta, quando, também, são mais pronunciados os efeitos prejudiciais da doença. Em cana-soca, comprovou-se que há, ainda, interferência da infecção de $C$. paradoxa ocorrida em cana- 
planta, no rendimento agricola (t/ha), embora tenha sido observado recuperação nesta produção em todos os tratamentos estudados, inclusive naqueles com maior intensidade (\%) de podridão-abacaxi. Também, já era esperado uma diluição dos efeitos da doença na produção da cana-soca, dada a maior capacidade de emissão de perfilhos das soqueiras, não restritas tão somente a uma gema inicial. Observou-se que as perdas calculadas em cana soca, embora o rendimento médio fosse superior àquele produzido em cana planta, foram reduzidas a indices inferiores a $50 \%$ das perdas observadas no corte anterior.

O ajuste mostrado na Tabela 14, apresenta em cana-planta e em canasoca, equações de regressão linear e quadrática com os respectivos coeficientes de determinação. A escolha do modelo que pretente exprimir as relações do rendimento agrícola ou perdas, e intensidade (\%) de podridãoabacaxi em cana-de-açúcar, deve assumir o condicionamento básico exposto por TENG (1981) quando afirmou que o aperfeiçoamento do modelo ajustado aos dados, como numa regressão polinomial, não muda a natureza inerentemente linear da análise de regressão, embora muitos processos biológicos não sejam lineares; no caso dos dados obtidos de intensidade (\%) de podridão-abacaxi e o rendimento da cana-de-açúcar, observa-se tendência nitidamente linear. Admite-se, dessa forma as equaçōes de "regressão linear simples" construidas com os dados de cana planta e cana-soca, para representar as relações entre intensidade (\%) de podridão-abacaxi aos 70 dias do plantio e os consequentes rendimentos agricolas (t/ha) ou perdas, na cultura da cana-de-açúcar. O coeficiente de determinação $r^{2}=0,836$ para cana-planta, admite que $84 \%$ da variação dos valores do rendimento agrícola foram explicados pela equação construida, o que segundo TENG (1987) define um bom modelo. A regressão apresentou, pelo teste $F$, significância ao nível de $1 \%$ de probabilidade. Da mesma forma pode-se interpretar a equação construida com os dados da cana-soca. 
Para a utilização prática do modelo, transformando-o numa forma mais objetiva, pode-se transformar a variável dependente " $y$ " em perdas provocadas na produçāo agricola, decorrentes dos niveis de intensidade (\%) de podridãoabacaxi encontrados. Para isso as equações de regressão linear assumem os valores apresentados abaixo, e calculados conforme os dados da Tabela 13:

- Para cana-planta $\rightarrow \quad y=0,46 x-20,51$

- Para cana-soca $\rightarrow y=0,22 x-9,90$,

sendo " $y$ " = perdas em t/ha e " $x$ " a intensidade (\%) de podridão-abacaxi aos 70 dias do plantio. Estas equações sintetizam todas as relações doençaperdas de produção desenvolvidas no ensaio de campo, e definem os modelos propostos para quantificarem as perdas provocadas pela podridão-abacaxi em cana-de-açúcar.

Para facilidade de interpretação, os modelos construidos podem ser transferidos para as formas apresentadas a seguir :

- Em cana-planta $\rightarrow y=0,46 x-20,51 \Rightarrow y=0,46(x-44,59)$

- Em cana-soca $\rightarrow y=0,22 x-9,90 \Rightarrow y=0,22(x-45,00)$,

onde os valores 44,59 em cana-planta, e 45,00 em cana-soca, definem a \% de intensidade de infecção considerada como o limiar de dano causado pela podridão-abacaxi em cana-de-açúcar, medida pela sua severidade aos 70 dias após o plantio.

Graficamente estas expressões tem o formato apresentado a seguir. 


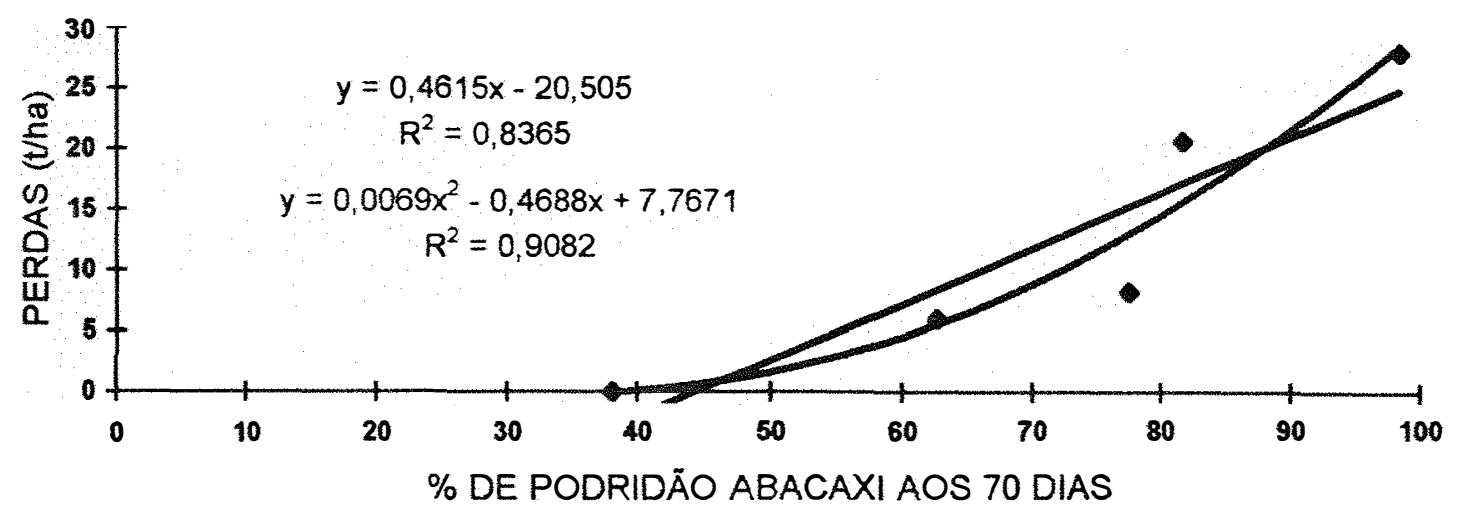

Figura 1: Avaliação de perdas por podridão-abacaxi em cana-planta.

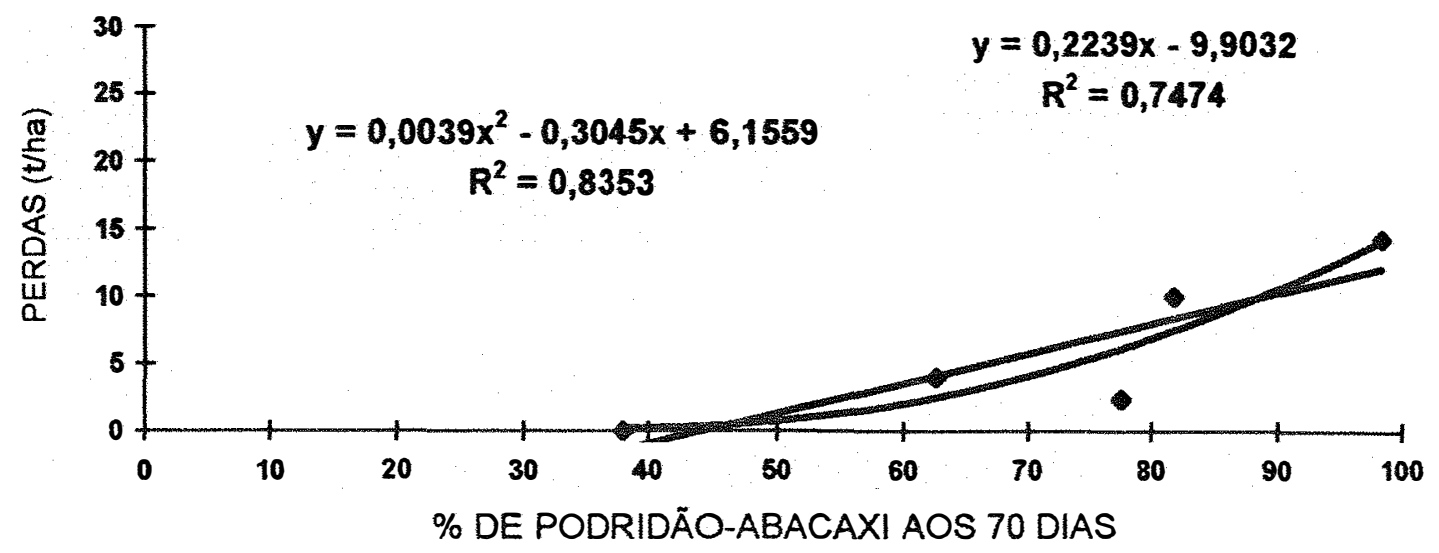

Figura 2: Avaliação de perdas por podridão-abacaxi em cana-soca. 


\subsubsection{Testes dos modelos propostos de perdas por podridão-} abacaxi

Desenvolvidos os modelos empíricos de regressão que relacionam o nivel de doença (Podridão-abacaxi dos toletes da cana-de-açúcar), com as perdas observadas na produção agrícola, $y=0,46 x-20,51$ (cana-planta) e $y=$ 0,22x - 9,90 (cana-soca), com " $y$ " igual a perdas (t/ha) e " $x$ " a intensidade (\%) de doença medida aos 70 dias do plantio, e avaliadas as suas exatidões através da significância do teste $F$ e do coeficiente de determinação $r^{2}$, em relação aos seus dados básicos de desenvolvimento, resta conhecer a habilidade destes modelos em efetuarem previsões de perdas com dados não utilizados como variável independente, na construção das equações de regressão.

Informações de TENG (1981) consideram que o teste do modelo proposto pode ser realizado de duas formas:

a) sua aplicação em amplo programa de avaliação de perdas e medir sua utilização em diversos ciclos da cultura. Isto pode ser admitido em relação a futuras observações, partindo-se do modelo ora disponivel;

b) aplicação de testes estatísticos para se avaliar a adaptação do modelo em relação aos dados de perdas por ele previstos e aqueles observados.

O procedimento de colocar a estimativa do modelo construido, em contraste com os dados de perda observados, analisados segundo a regressão linear dos valores encontrados, fornece indicadores da precisão das estimativas.

Os valores projetados a seguir permitem a definição desta análise, sendo " $x$ " a intensidade (\%) de podridão-abacaxi observada e " $y$ " as perdas em toneladas por hectare encontradas. A estimativa " $y$ ' ", defin as perdas calculadas a partir da aplicação dos modalos propostos : $y=0,46 x-20,51$ para cana-planta, e $y=0,22 x-9,90$ para cana-soca. 


\begin{tabular}{ccc}
\multicolumn{3}{c}{ CANA-PLANTA } \\
\hline $\mathbf{x}$ & $\mathbf{y}$ (observado) & $\mathbf{y}^{\prime}$ (estimado) \\
\hline INT $\%$ & tha & tha \\
\hline 38,1 & 0,0 & $-2,98$ \\
62,6 & 6,0 & 8,28 \\
77,5 & 8,2 & 15,14 \\
81,7 & 20,6 & 17,07 \\
98,3 & 28,0 & 24,71 \\
\hline
\end{tabular}

\begin{tabular}{ccc}
\multicolumn{3}{c}{ CANA-SOCA } \\
\hline $\mathbf{x}$ & $\mathbf{y}$ (observado) & $\mathbf{y}^{\prime}$ (estimado) \\
\hline INT \% & t/ha & t/ha \\
\hline 38,1 & 0,0 & $-1,52$ \\
62,6 & 4,0 & 3,87 \\
77,5 & 2,4 & 7,15 \\
81,7 & 10,0 & 8,07 \\
98,3 & 14,3 & 11,73 \\
\hline
\end{tabular}

As Figuras 3 e 4, a seguir, determinam as regressões lineares dos valores de perdas por podridão-abacaxi observados no campo e estimados através dos modelos propostos. Os coeficientes de determinação $r^{2}=0,84$ (cana-planta) e $r^{2}=0,75$ (cana-soca) observados, admitem concluir que os modelos construidos têm boa capacidade de respostas às "entradas" de intensidade (\%) de ocorrência de podridão-abacaxi mensurado aos 70 dias do plantio da cana-de-açúcar, com ajuste superior daquele desenvolvido para cana-planta. 


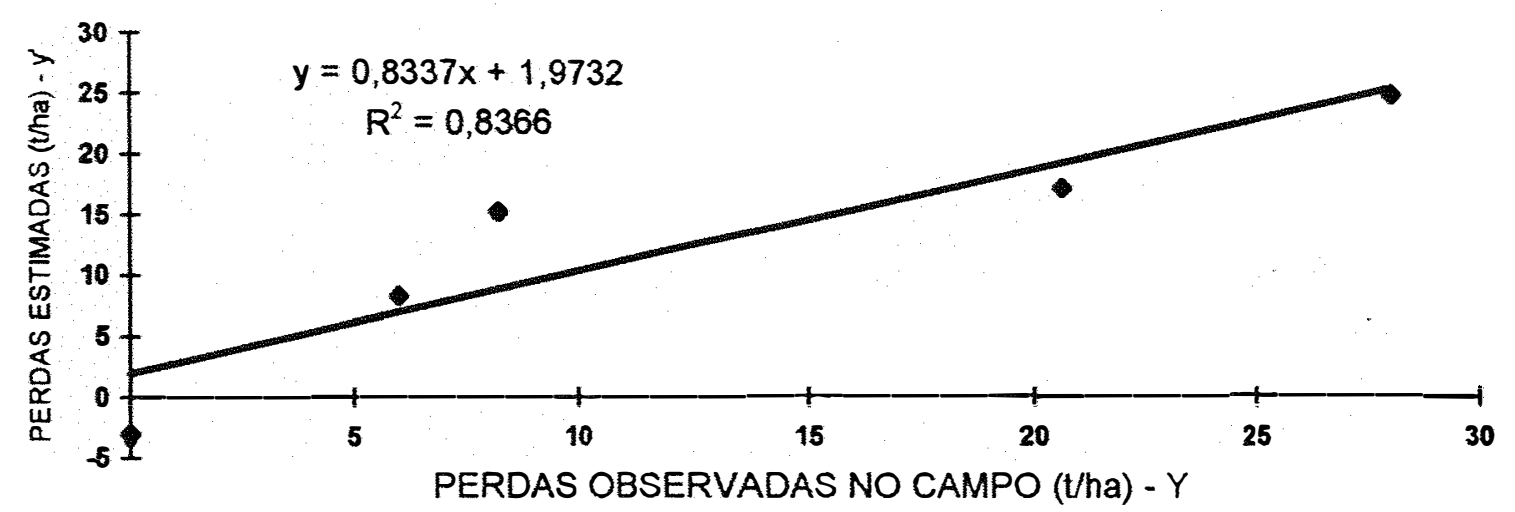

Figura 3: Teste do modelo de previsão de perdas por podridão-abacaxi em cana-planta.

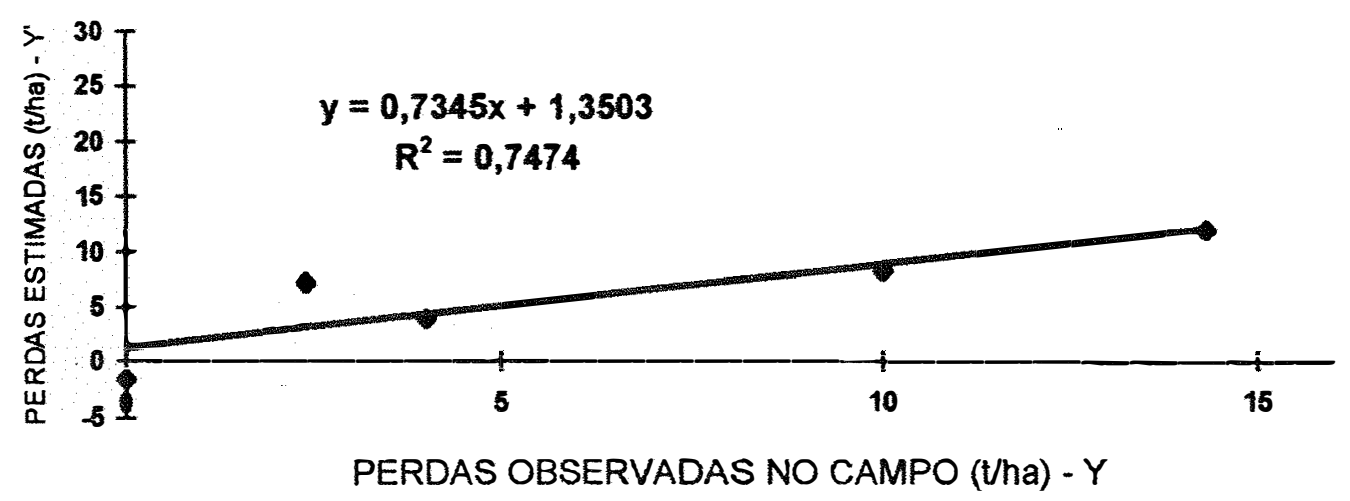

Figura 4: Teste do modelo de previsão de perdas por podridão-abacaxi em cana-soca. 
Conforme esperado, uma vez que as retas de regressão apresentaram bons coeficientes de determinação $\left(r^{2}=0,84\right.$ e $\left.r^{2}=0,75\right)$, o coeficiente angular não diferiu de 1,0 ao nivel de $1 \%$ de probabilidade pelo teste $t$. 


\section{5 - CONCLUSŌES}

Pelas análises e discussões procedidas nos dados obtidos do ensaio de campo conduzido, diante dos objetivos propostos e desenvolvidos neste trabalho, permite-se as seguintes conclusões :

1 - O sistema tradicional de plantio da cana-de-açúcar, com seccionamento dos colmos em toletes de 3 gemas, se realizado em épocas de temperaturas amenas e umidade baixa ou excessiva (outono), proporciona intensidade (\%) de infecção de podridão-abacaxi em praticamente $100 \%$ dos tecidos dos toletes, medido pela severidade observada aos 70 dias após 0 plantio.

2 - A aplicação de proteção química no sistema de plantio em toletes de 3 gemas, em situações climáticas desfavoráveis à brotação inicial, embora apresente ganhos na brotação inicial das gemas, não proporciona aumento de produção agrícola, comparado ao sistema de plantio semelhante e sem a proteção química. 
3 - Mesmo quando não apresenta redução na brotação inicial das gemas, o fungo C. paradoxa exerce clara ação fitotóxica, impedindo o desenvolvimento normal dos colmos, cuja touceira foi anteriormente contaminada.

4 - Como técnica cultural para o controle da podridão-abacaxi, principalmente nos plantios sob condições de temperatura e umidade irregulares, recomenda-se o mínimo seccionamento do colmo utilizado como muda, ou até mesmo o uso da cana inteira. Este procedimento não altera a qualidade do plantio, a população de colmos industrializáveis produzidos e o rendimento agrícola, se a muda utilizada for de idade próxima a 12 meses.

5 - A estimativa dos prejuizos, em cana-planta, relativos à ocorrência de podridão-abacaxi em cana-de- açúcar, pode ser efetuada pela aplicação do modelo empírico linear desenvolvido e representado pela equação $y=0,46(x-44,59)$, onde " $y$ " é a perda de produção em toneladas por hectare e " $x$ " a intensidade $(\%)$ de podridão-abacaxi, medida pela sua severidade aos 70 dias após o plantio. Segundo o presente modelo, as perdas se iniciam na faixa de $40 \%$ de intensidade de infecção ( $44,59 \%$ ), com valores de 0,46 t/ha para cada aumento de $1 \%$ neste indice. Os campos para a aplicação deste modelo devem possuir qualidade mínima de plantio, com indice menor ou igual a $50 \%$ no comprimento total das falhas maiores que 50 centímetros. 


\section{REFERÊNCIAS BIBLIOGRÁFICAS}

AMORIM, L. Avaliação de doenças. In: BERGAMIN FILHO, A.; KIMATI, H.; AMORIM, L., ed. Manual de fitopatologia; principios e conceitos. $3^{\mathrm{a}}$ ed. São Paulo, Agronômica Ceres, 1995. cap. 32, p.647-671.

ARCENEAUX, G. Some practical means of improving stands of sugarcane under Louisiana conditions. Sugar Bulletin, New Orleans, 26(4):404, 411-413, Sept. 1948.

BANZATTO, D.A. \& KRONKA, S.N. Experimentação agricola. Jaboticabal, FUNEP, 1992. 247p.

BERGAMIN FILHO, A. Avaliação de danos e perdas. In: BERGAMIN FILHO, A.; KIMATI, H.; AMORIM, L., ed. Manual de fitopatologia; principios e conceitos. $3^{a}$ ed. São Paulo, Agronômica Ceres, 1995. cap.33, p.672690.

BERGAMIN FILHO, A. \& AMORIM, L. Avaliação de doenças e perdas. Summa Phytopathologica, Jaguariúna, 17(1):57-67, jan./fev. 1991. 
BOYD, H. W. \& GALLI, F. Efeito do armazenamento da cana-de-açúcar sobre a "germinação" e sobre a incidência da podridão-abacaxi, causada por Ceratocystis paradoxa (de Seynes) Moreau. Anais da ESALQ, Piracicaba, 23:229-245, 1966.

BOYD, H. W. \& ALLISON, C.C. Studies of the host-parasite relationship in the pineapple disease of sugarcane. Phytopatology, Lancaster, 58(6):839842, 1968.

BRITO, S.A. Efeito de tamanhos de toletes e de cana inteira com e sem desponte, na produção de cana-de-açúcar. Viçosa, $1988.50 p$. (Mestrado - Universidade Federal de Viçosa).

BURR, G.O.; HARTT, C.E.; BRODIE, H.W.; TANIMOTO, T.; KORTSCHAK, H.P.; TAKAHASHI, D.; ASHTON, F.M.; COLEMAN, R.E. The sugarcane plant. Annual Review of Plant Physiology, Palo Alto, 8:275-308, 1957.

BYTHER, R.S. \& STEINER, G.W. Root inhibition of sugarcane seedpieces by Ceratocystis paradoxa. Phytopathology, Lancaster, 60(9):1287, 1970.

CAMARGO, P.N. Fisiologia da cana-de-açúcar. Piracicaba, ESALQ/DAH, 1970. 38p.

CHESTER, K.S. Plant diseases losses; their appraisal and interpretation. Plant Disease Reporter Supplement, Beltsville, (193):190-362, June 1950.

CHIARAPPA, L.; MOORE, F.J.; STRICKLAND, A.H. Introduction. In: FAO. Rome. Crop loss assessment methods. Farnham Royal, CAB, 1971. Chap. 1, p.1.1-1.3.

CHOW, N.P. Number of buds per seed piece in relation to germination, growth and yield of sugar cane. Report of the Taiwan Sugar Exp. Sta., Tainan, (5):91-108, 1949.

FAO. Rome. Crop loss assessment methods. Farnham Royal, CAB, 1971. p.ir. 
GAUNT, R.E. Measurement of disease and pathogens. In: TENG, P.S. Crop loss assessment and pest management. St. Paul, APS, 1987. Chap. 2 , p.6-18.

HILTON, H.W.; WISMER, C.A.; NOMURA, N.S. Benomyl seedpiece treatment for sugarcane and its analysis. Hawaiian Planter's Record, Honolulu, 58(12):159-164, 1971.

HUGHES, C.G. Diseases of sugarcane; a review. PANS, London, 24(2):143159, 1978.

HUMBERT, R.P. El cultivo de la caña de azucar. México, Continental, 1974. $719 p$.

IAAJPLANALSUCAR. Relatório anual 1972. Rio de Janeiro, 1972. 32p.

IAAJPLANALSUCAR. Relatório anual 1974. Piracicaba, 1974. 68p.

IAAJPLANALSUCAR. Relatório anual 1975. Piracicaba, 1976. 80p.

JAMES, W.C. Assessment of plant diseases and losses. Annual Review of Phytopathology, Palo Alto, 12:27-48, 1974.

JAMES, W.C. \& TENG, P.S. The quantification of production constraints associated with plant diseases. In: COAKER, T.H. ed. Applied biology. London, Academic Press, 1979. v.4, p.201-267.

KANWAR, R.S.; SHARMA, H.L.; AULAKH, M.S. Effect of piece size on germination and yield of sugar cane. Sugar News, Bombay, 6(9):3-11, 1975. Apud Brasil Açucareiro, Rio de Janeiro, 86(3):74, 1975. (Resumo)

KRANZ, J. Measuring plant disease. In: KRANZ, J. \& ROTEM, J., ed. Experimental techniques in plant disease epidemiology. Berlin, Springer-Verlag, 1988. chap.3, p.35-50.

KUO, T.; CHIEN, M.; LI, H. Ethyl acetate produced by Ceratocystis paradoxa and $C$. adiposum and its role in the germination of sugarcane buds. Canadian Journal of Botany, Ottawa, 47(9):1459-1463, 1969. 
LARGE, E.C. Measuring plant diseases. Annual Review of Phytopathology, Palo Alto, 4:9-28, 1966.

LEE, T.S.G. Efeito do plantio de cana inteira na germinação, desenvolvimento e na produção da cana-de-açúcar. Cadernos PLANALSUCAR, Piracicaba, 3(1):13-18, fev. 1984.

LEE, T.S.G.; MARTINS, J.; MATSUOKA, S.; MAGALHÃES, P.M.; SILVA, M.R.; CASTILHO, H.J.; FURLANI NETO, V.L. Plantio de cana inteira; viabilidade e recomendações. Saccharum APC, São Paulo, 9(43):20-23, maio/out. 1986.

LONDSDALE, J.E. Planting deepth and seed material for establishment of sugarcane. In: CONGRESS INTERNATIONAL SOCIETY SUGAR CANE TECHNOLOGISTS, 16, São Paulo, 1977. Proceedings. São Paulo, ISSCT, 1977. v.2, p.945-961.

MA, Y.C. Planting the whole stalk seed cane TSC plantation. Taiwan Sugar, Tainan, 27(4):130, 1980.

MATSUOKA, S. \& GHELLER, A.C.A. Técnica cultural para controle da Podridão Abacaxi ( Ceratocystis paradoxa [Dade] Moreau ) em cana-de açúcar ( Saccharum spp. ). Summa Phytopathologica, Piracicaba, 10(1,2):119 - 121, jan/jun. 1984.

McMARTIN, A. Pineapple disease of sugarcane cuttings and its control. In: ANNUAL CONGRESS SOUTH AFRICAN SUGAR TECHNOLOGISTS ASSOCIATION, 18., Durban, 1944. Proceedings. Mount Edgecombe, SASTA, 1944. p.44-46.

PIMENTEL GOMES, F. Curso de estatística experimental. $\quad 4^{\text {a }}$ ed. Piracicaba, Nobel, 1970. 430p. 
SAH, D.N. \& MACKENZIE, D.R. Methods of generating different levels of disease epidemics in loss experiments. In: TENG, P.S. ed. Crop loss assessment and pest management. St. Paul, APS, 1987. Chap.9, p.9096.

SHANE, W.W. \& TENG, P.S. Generating the database for disease-loss modeling. In: TENG, P.S. ed. Crop loss assessment and pest management. St. Paul, APS, 1987. Chap. 8, p.82-89.

SORDI, R.A. Efeito da podridão abacaxi (Thielaviopsis paradoxa De SeynesV.HOHN) em algumas variedades de cana-de-açúcar (Saccharum spp). In: CONGRESSO PAULISTA DE FITOPATOLOGIA, 6., Araras, 1983. Resumos. Araras, IAAJPLANALSUCAR. COSUL, 1983a. p.28.

SORDI, R.A. Controle preventivo da podridão abacaxi (Thielaviopsis paradoxa) e do carvão (Ustilago scitaminea) da cana-de-açúcar com um mesmo fungicida. In: CONGRESSO PAULISTA DE FITOPATOLOGIA, 6., Araras, 1983. Resumos. Araras, IAAPLANALSUCAR. COSUL, 1983b. p.41.

STOLF, R. Transplantio de soqueira de cana-de-açúcar como técnica de renovação da cultura. Piracicaba, 1983. 100p. (Doutoramento-Escola Superior de Agricultura "Luiz de Queiroz"/USP).

STOLF, R. Metodologia de avaliação de falhas nas linhas de cana-de-açúcar. STAB, Piracicaba, 4(6):22-36, jul./ago. 1986.

STOLF, R.; IAIA, A.M.; LEE, T.S.G. Índice de falha segundo o método de STOLF; correlação com o rendimento agrícola em cana planta. Brasil Açucareiro, Rio de Janeiro, 104(5/6):44-50, 1986.

STOLF, R.; IAIA, M.A.; LEE, T.S.G. Indice de falhas segundo o método STOLF; correlação com o rendimento agrícola em soqueiras de cana-deaçúcar. Álcool \& Açúcar, São Paulo, 11(58):12-16, maio/jun. 1991.

TENG, P.S. Use of regression analysis for developing crop loss models. In: FAO. Rome. Crop loss assessment methods. Farnham Royal, CAB, 1981. p.51-55. (Suppl., 3). 
TENG, P.S. Construction of predictive models; 2. forecasting crop losses. Advances in Plant Pathology, London, 3:179-206, 1985.

TENG, P.S. Quantifying the relationship between disease intensity and yield loss. In: ed. Crop loss assessment and pest management. St. Paul, APS, 1987. chap.11, p.105-113.

TENG, P.S. \& JOHNSON, K.B. Analysis epidemiological components in yield loss assessment. In: KRANZ, J. \& ROTEM, J. ed. Experimental techniques in plant disease epidemiology. Berlin, Springer-Verlag, 1988. chap. 12, p.179-189.

TOKESHI, H. Doenças da cana-de-açúcar. In: GALLI, F., coord. Manual de fitopagologia; doenças das plantas cultivadas. São Paulo, Agronômica Ceres, 1980. cap. 12, p.141-206.

VAN DILLEWIJN, C. The germination of sugarcane. Sugar Journal, New Orleans, 10(12):3-6, 20-23, May 1948.

VAN DILLEWIJN, C. Botany of sugarcane. Waltham, Chronica Botanica, 1952. $371 p$.

WISMER, C.A. Pineapple disease. In: MARTIN, J.P. et al (ed.). Sugar-cane diseases of the world. Amsterdam, Elsevier, 1961. v.1, chap.10, p.223245.

WISMER, C.A. \& BAILEY, R.A. Pineapple disease. In: RICAUD, C. et ali, ed. Diseases of sugarcane; major diseases. Amsterdam, Elsevier, 1989. chap.10, p.145-155.

YANG, P.C.; LO, C.C.; HO, F.W., YIN, S.A. A study of planting whole-stalk seed cane, its germination, growth and sugar cane yield. Report Taiwan Sugar Research Institute, Tainam, (94):19-32, 1981.

ZADOKS, J.C. The concept of thresholds; warning, action and damage thresholds. In: TENG, P.S., ed. Crop loss assessment and pest management. St. Paul, APS, 1987. chap. 18, p.168-175. 
APÊNDICES 
Apêndice 1. a. Dados de precipitação pluvial e temperatura do ar durante o ano de 1983 - Estação Experimental do IAAJPLANALSUCAR, Araras-SP

\begin{tabular}{lcccc}
\hline 1983 & PRECIPITAÇÃO & \multicolumn{3}{c}{$t\left({ }^{\circ} \mathbf{C}\right)$ do ar } \\
\cline { 3 - 5 } & $(\mathbf{m m})$ & MÁXIMA & MÍNIMA & MÉDIA \\
\hline JAN & 300,0 & 28 & 18,4 & 23,2 \\
FEV & 354,6 & 29,8 & 18,2 & 24,0 \\
MAR & 375,6 & 28,4 & 17,4 & 23,0 \\
ABR & 105,0 & 26,6 & 16,6 & 21,6 \\
MAI & 192,8 & 25,6 & 14,9 & 20,2 \\
JUN & 104,1 & 23,4 & 13,0 & 18,2 \\
JUL & 39,8 & 26,3 & 12,9 & 19,6 \\
AGO & 0 & 26,8 & 11,0 & 18,7 \\
SET & 255,6 & 23,7 & 12,7 & 18,2 \\
OUT & 103,3 & 27,2 & 15,7 & 21,4 \\
NOV & 118,8 & 29,0 & 16,7 & 22,8 \\
DEZ & 329,8 & 27,6 & 18,1 & 22,8 \\
\hline TOTAL & $\mathbf{2 . 2 7 9 , 9}$ & & & \\
\hline
\end{tabular}

b. Normais climatólogicas de Araras/SP (Média de 30 anos)

\begin{tabular}{lcccc}
\hline & PRECIPITAÇÃO & \multicolumn{3}{c}{ t ( ${ }^{\circ} \mathbf{C}$ ) do Ar } \\
\cline { 3 - 5 } MÊS & $(\mathbf{m m})$ & MÁXIMA & MÍNIMA & MÉDIA \\
\hline & & & & \\
JAN & 238,5 & 29.3 & 17.8 & 22.6 \\
FEV & 205.6 & 29.2 & 18.0 & 22.5 \\
MAR & 169.1 & 29.0 & 17.1 & 22.0 \\
ABR & 61.4 & 27.5 & 14.5 & 20.1 \\
MAI & 46.4 & 25.5 & 12.2 & 18.1 \\
JUN & 36.4 & 24.6 & 11.0 & 17.0 \\
JUL & 24.5 & 24.8 & 10.4 & 16.7 \\
AGO & 27.9 & 27.2 & 11.7 & 18.6 \\
SET & 59.4 & 28.3 & 13.3 & 20.1 \\
OUT & 133.3 & 28.3 & 14.8 & 20.8 \\
NOV & 146.6 & 28.6 & 15.5 & 21.4 \\
DEZ & 229.4 & 28.8 & 16.8 & 21.9 \\
\hline
\end{tabular}




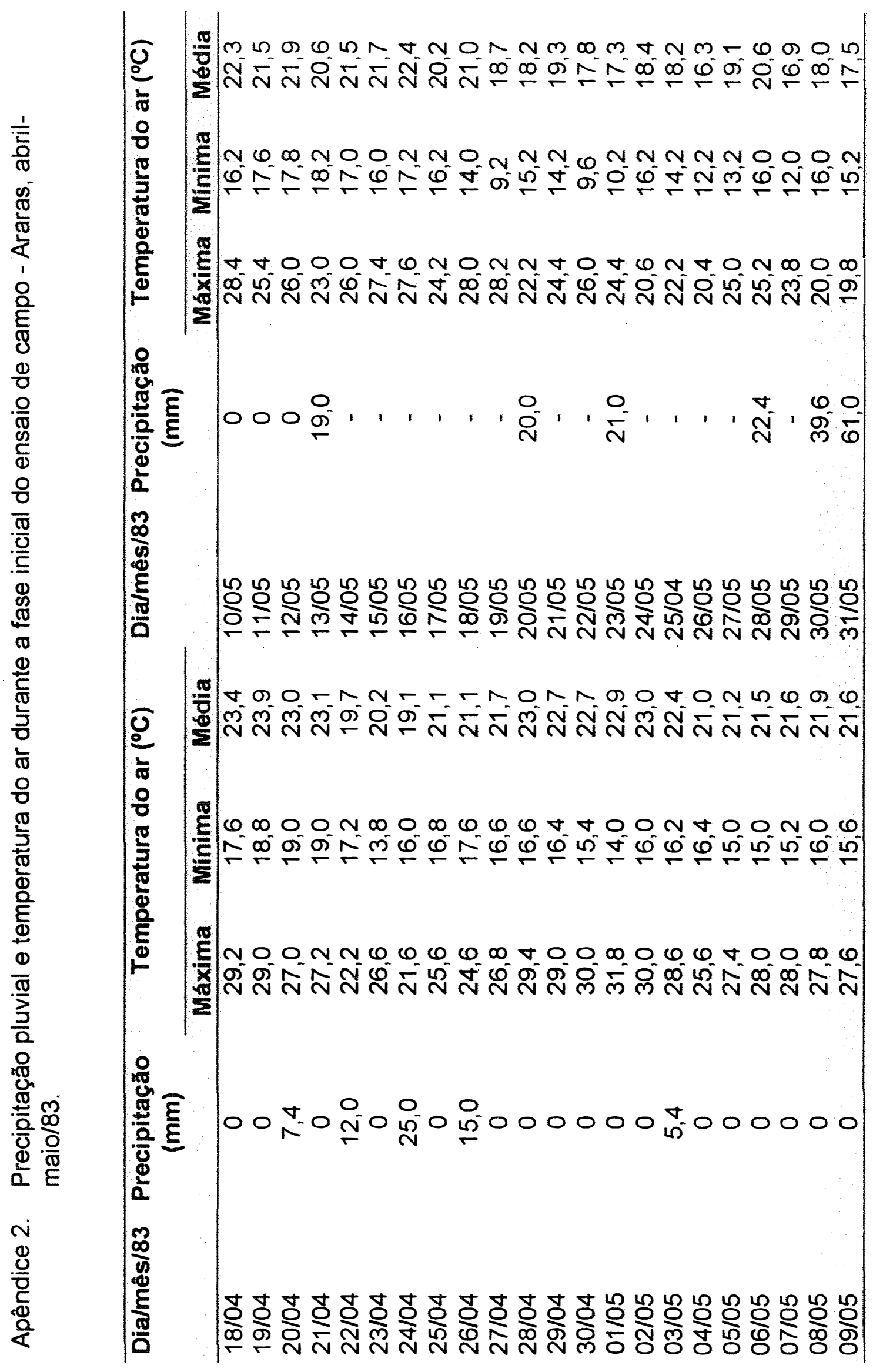


Apêndice 3. Dados coletados e análise de variância para a avaliação da brotação inicial das gemas de cana-de-açúcar aos 50 dias do plantio ( $n^{\circ}$ brotos/parcela).

a) Dados de brotação inicial aos 50 dias

\begin{tabular}{lllllll}
\hline Variedades & Tratamentos & BI & BII & BIII & BIV & M \\
\hline \multirow{5}{*}{ NA56-79 } & 3G & 90 & 60 & 57 & 68 & 69 \\
& 3G + B & 79 & 97 & 112 & 53 & 85 \\
& 6G & 155 & 112 & 110 & 116 & 123 \\
& CTS & 105 & 211 & 117 & 131 & 141 \\
& CINT & 121 & 144 & 161 & 157 & 146 \\
\hline \multirow{5}{*}{ RB725828 } & $3 G$ & 97 & 103 & 88 & 56 & 86 \\
& 3G + B & 119 & 104 & 226 & 174 & 156 \\
& GG & 157 & 135 & 153 & 184 & 157 \\
& CTS & 170 & 187 & 139 & 170 & 166 \\
& CINT & 120 & 126 & 117 & 128 & 123 \\
\hline \multirow{5}{*}{ RB735275 } & GG & 154 & 152 & 130 & 140 & 144 \\
& 3G + B & 121 & 129 & 215 & 302 & 192 \\
& GG & 189 & 229 & 224 & 187 & 207 \\
& CTS & 182 & 220 & 208 & 204 & 203 \\
& CINT & 210 & 190 & 185 & 135 & 180 \\
\hline
\end{tabular}

$3 \mathrm{G}=3$ Gemas; $3 \mathrm{G}+\mathrm{B}=3$ Gemas + Benlate; $6 \mathrm{G}=6$ Gemas; CTS = Corte no

Terço Superior; CINT = Cana Inteira

b) Análise de variância

\begin{tabular}{lcc}
\multicolumn{1}{c}{ C. Variação } & G.L. & QM \\
\hline Blocos & 3 & 380,9944 \\
Variedades $(\mathrm{V})$ & 2 & $27147,6500^{\star \star}$ \\
Residuo (a) & 6 & 372,0278 \\
\hline Parcelas & $(11)$ & - \\
\hline Tratamentos $(\mathrm{T})$ & 4 & $9102,3750^{\star \star}$ \\
Vx & 8 & 1304,7125 \\
Residuo (b) & 36 & 1357,4889 \\
\hline Total & 59 & - \\
\hline
\end{tabular}


c) Médias observadas e respectivas diferenças mínimas significativas, calculadas pelo método de Tukey, para variedades e tratamentos.

\begin{tabular}{cc} 
Médias & $\begin{array}{c}\text { Brotação Inicial } \\
\text { (50 dias) }\end{array}$ \\
\hline Nariedades & 113 \\
RB725-79 & 138 \\
RB735275 & 185 \\
\hline$\Delta(5 \%)$ & 19 \\
\hline Tratamentos & - \\
\hline $3 G$ & 100 \\
$3 G+B$ & 144 \\
$6 G$ & 163 \\
CTS & 170 \\
CINT & 150 \\
\hline$\Delta(5 \%)$ & 43 \\
\hline CV\% $(N)$ & 13,2 \\
CV\% (T) & 25,3 \\
\hline
\end{tabular}


Apêndice 4. Dados coletados e análise de variância para a avaliação do número de perfilhos de cana-de-açúcar aos 110, 200 e 310 dias do plantio.

a) Número de perfilhos/parcela aos 110 dias do plantio

\begin{tabular}{|c|c|c|c|c|c|c|}
\hline Variedades & Tratamentos & BI & BII & BIII & BIV & $\mathbf{M}$ \\
\hline \multirow{5}{*}{ NA56-79 } & $3 G$ & 206 & 189 & 193 & 195 & 196 \\
\hline & $3 G+B$ & 228 & 235 & 303 & 168 & 233 \\
\hline & $6 G$ & 379 & 291 & 270 & 285 & 306 \\
\hline & CTS & 313 & 359 & 340 & 218 & 307 \\
\hline & CINT & 333 & 350 & 413 & 382 & 344 \\
\hline \multirow{5}{*}{ RB725828 } & $3 G$ & 177 & 153 & 179 & 102 & 153 \\
\hline & $3 G+B$ & 203 & 159 & 371 & 258 & 248 \\
\hline & $6 \mathrm{G}$ & 229 & 220 & 224 & 318 & 248 \\
\hline & CTS & 401 & 301 & 296 & 272 & 317 \\
\hline & CINT & 207 & 238 & 224 & 241 & 227 \\
\hline \multirow{5}{*}{ RB735275 } & $3 G$ & 310 & 234 & 245 & 253 & 260 \\
\hline & $3 G+B$ & 223 & 191 & 374 & 600 & 347 \\
\hline & $6 G$ & 349 & 424 & 388 & 339 & 375 \\
\hline & CTS & 374 & 417 & 345 & 483 & 405 \\
\hline & CINT & 446 & 454 & 433 & 297 & 407 \\
\hline \multicolumn{7}{|c|}{ b) Número de perfilhos/parcela aos 200 dias do plantio } \\
\hline \multirow[t]{2}{*}{ Variedades } & Tratamentos & BI & BII & BIII & BIV & M \\
\hline & $3 G$ & 635 & 578 & 636 & 662 & 628 \\
\hline \multirow{4}{*}{ NA56-79 } & $3 G+B$ & 697 & 643 & 777 & 531 & 662 \\
\hline & 6G & 795 & 723 & 865 & 803 & 797 \\
\hline & CTS & 693 & 718 & 865 & 758 & 759 \\
\hline & CINT & 737 & 813 & 766 & 676 & 748 \\
\hline \multirow{5}{*}{ RB725828 } & $3 G$ & 554 & 425 & 520 & 343 & 461 \\
\hline & $3 G+B$ & 673 & 612 & 824 & 817 & 732 \\
\hline & 6G & 784 & 701 & 700 & 859 & 761 \\
\hline & CTS & 915 & 785 & 833 & 695 & 807 \\
\hline & CINT & 676 & 704 & 603 & 704 & 672 \\
\hline \multirow{5}{*}{ RB735275 } & $3 \mathrm{G}$ & 923 & 791 & 762 & 691 & 792 \\
\hline & $3 G+B$ & 746 & 736 & 937 & 1023 & 861 \\
\hline & $6 \mathrm{G}$ & 923 & 855 & 605 & 908 & 823 \\
\hline & CTS & 878 & 842 & 864 & 783 & 842 \\
\hline & CINT & 745 & 879 & 1000 & 779 & 851 \\
\hline
\end{tabular}


c) Número de perfilhos/parcela aos 310 dias do plantio

\begin{tabular}{llllllc}
\hline Variedades & Tratamentos & BI & BII & BIII & BIV & M \\
\hline \multirow{5}{*}{ NA56-79 } & $3 G$ & 540 & 523 & 524 & 568 & 538 \\
& 3G + B & 521 & 512 & 563 & 521 & 529 \\
& 6G & 617 & 577 & 561 & 600 & 588 \\
& CTS & 520 & 512 & 520 & 592 & 536 \\
& CINT & 577 & 583 & 564 & 547 & 567 \\
\hline \multirow{5}{*}{ RB725828 } & 3G & 520 & 463 & 487 & 449 & 479 \\
& 3G + B & 611 & 544 & 627 & 591 & 593 \\
& GG & 662 & 597 & 624 & 607 & 622 \\
& CTS & 694 & 463 & 609 & 673 & 609 \\
& CINT & 654 & 603 & 593 & 639 & 622 \\
\hline & 3G & 576 & 509 & 552 & 501 & 534 \\
RB735275 & 3G + B & 543 & 472 & 576 & 566 & 539 \\
& 6G & 591 & 575 & 574 & 597 & 584 \\
& CTS & 581 & 572 & 579 & 623 & 588 \\
& CINT & 594 & 585 & 604 & 569 & 588 \\
\hline
\end{tabular}

d) Análise de variância

\begin{tabular}{|c|c|c|c|c|}
\hline \multirow[t]{2}{*}{ C.Variaçao } & \multirow[t]{2}{*}{ G.L. } & \multicolumn{3}{|c|}{ Quadrados Médios } \\
\hline & & 110 dias & 200 dias & 310 dias \\
\hline Blocos & 3 & 1645,17 & 7593,73 & 6229,52 \\
\hline Variedades & 2 & $74131,71^{\star \star}$ & $119678,21^{\star \star}$ & 5600,61 \\
\hline Residuo (a) & 6 & 2912,89 & 3595,08 & 1611,99 \\
\hline Parcelas & (11) & - & - & - \\
\hline Tratamentos $(\mathrm{T})$ & 4 & $38815,10^{\star \star}$ & $59452,02^{\star \star \star}$ & $13121,01^{\text {th }}$ \\
\hline$V \times T$ & 8 & 4151,57 & 18436,11 & $3507,67^{\text {** }}$ \\
\hline Resíduo (b) & 36 & 5432,90 & 9410,82 & 1078,15 \\
\hline Total & 59 & - & - & - \\
\hline
\end{tabular}


e) Médias observadas e respectivas diferenças mínimas significativas calculadas pelo método de Tukey, para variedades e tratamentos.

\begin{tabular}{lccc}
\multicolumn{1}{c}{ Médias } & \multicolumn{3}{c}{ Número de Perfilhos (dias) } \\
\hline \multicolumn{1}{c}{ Variedades } & $\mathbf{1 1 0}$ & $\mathbf{2 0 0}$ & $\mathbf{3 1 0}$ \\
\hline NA56-79 & 282 & 719 & 552 \\
RB725828 & 239 & 686 & 586 \\
RB735275 & 359 & 834 & 567 \\
\hline$\Delta(5 \%)$ & 52 & 58 & 39 \\
\hline Tratamentos & & & \\
\hline $3 G$ & 203 & 627 & 518 \\
$3 G+B$ & 276 & 751 & 554 \\
6G & 310 & 793 & 598 \\
CTS & 343 & 802 & 578 \\
CINT & 335 & 757 & 593 \\
\hline$\Delta(5 \%)$ & 87 & 114 & 39 \\
\hline CV\% (V) & 18,4 & 8,0 & 7,0 \\
CV\% (T) & 25,1 & 13,0 & 5,8 \\
\hline
\end{tabular}

$3 G=3$ Gemas; $3 G+B=3$ Gemas + Benlate; $6 \mathrm{G}=6$ Gemas; $\mathrm{CTS}=$ Corte no Terço Superior; CINT = Cana Inteira 
Apêndice 5. Dados coletados e análise de variância para a avaliação do número de falhas observadas - dados transformados para $\sqrt{x+1}$, exceto para número total de falhas, onde os dados nao sofreram transformaçao.

a) Número de falhas em três classes, observadas aos 195 dias do plantio

\begin{tabular}{|c|c|c|c|c|c|c|c|c|c|c|c|c|c|c|c|}
\hline \multirow[t]{2}{*}{ Rep } & \multicolumn{3}{|c|}{$3 G$} & \multicolumn{3}{|c|}{$3 G+B$} & \multicolumn{3}{|c|}{ 6G } & \multicolumn{3}{|c|}{ CTS } & \multicolumn{3}{|c|}{ CINT } \\
\hline & $\begin{array}{l}50 \\
80 \mathrm{~cm}\end{array}$ & 81 & $i_{n a m}$ & 50 & 81 & $i_{120 \mathrm{~cm}}$ & $\begin{array}{l}50 \\
80 \mathrm{~cm}\end{array}$ & 81 & $720 \mathrm{~cm}$ & $\begin{array}{l}50 \\
80 \mathrm{~cm}\end{array}$ & ${ }_{18}^{81}$ & 20 & $\begin{array}{l}50 \\
80 \mathrm{~cm}\end{array}$ & 81 & $300 \mathrm{~cm}$ \\
\hline & \multicolumn{15}{|c|}{ NA56-79 } \\
\hline 1 & 13 & 3 & 0 & 9 & 2 & 0 & 14 & 2 & 0 & 15 & 7 & 1 & 7 & 10 & 5 \\
\hline 2 & 11 & 4 & 1 & 16 & 2 & 0 & 20 & 4 & 0 & 12 & 5 & 1 & 13 & 10 & 4 \\
\hline 3 & 13 & 0 & 0 & 7 & 2 & 0 & 13 & 2 & 0 & 14 & 4 & 0 & 11 & 5 & 7 \\
\hline 4 & 12 & 5 & 1 & 13 & 0 & 0 & 9 & 2 & 0 & 15 & 5 & 1 & 16 & 4 & 4 \\
\hline \multirow[t]{2}{*}{ Total } & 49 & 12 & 2 & 45 & 6 & 0 & 56 & 10 & 0 & 56 & 21 & 3 & 47 & 29 & 20 \\
\hline & \multicolumn{15}{|c|}{ RB725828 } \\
\hline 1 & 10 & 6 & 4 & 13 & 4 & 2 & 14 & 4 & 0 & 11 & 2 & 0 & 9 & 13 & 0 \\
\hline 2 & 18 & 5 & 3 & 10 & 4 & 4 & 17 & 0 & 0 & 4 & 2 & 0 & 9 & 4 & 8 \\
\hline 3 & 13 & 1 & 4 & 5 & 4 & 0 & 19 & 0 & 0 & 14 & 2 & 0 & 11 & 8 & 0 \\
\hline 4 & 14 & 9 & 7 & 4 & 0 & 0 & 9 & 1 & 0 & 11 & 3 & 0 & 12 & 7 & 2 \\
\hline Tolal & 55 & 21 & 18 & 32 & 12 & 6 & 59 & 5 & 0 & 40 & 9 & 0 & 41 & 32 & 10 \\
\hline \multicolumn{16}{|c|}{ RB735275 } \\
\hline 1 & 12 & 9 & 0 & 18 & 4 & 3 & 17 & 1 & 1 & 15 & 1 & 1 & 12 & 0 & 1 \\
\hline 2 & 5 & 6 & 6 & 12 & 8 & 1 & 6 & 2 & 0 & 8 & 2 & 0 & 12 & 3 & 1 \\
\hline 3 & 11 & 7 & 0 & 9 & 1 & 0 & 7 & 1 & 1 & 5 & 0 & 0 & 4 & 3 & 1 \\
\hline 4 & 14 & 3 & 3 & 3 & 0 & 1 & 16 & 1 & 0 & 9 & 3 & 0 & 10 & 1 & 1 \\
\hline Total & 42 & 25 & 9 & 42 & 13 & 5 & 46 & 5 & 2 & 37 & 6 & 1 & 38 & 7 & 4 \\
\hline
\end{tabular}

b) Análise de Variância

\begin{tabular}{lccccc}
\hline C.Variacăo & G.L. & \multicolumn{5}{c}{ Quadrados Médios } \\
\cline { 3 - 6 } & & $\mathbf{5 0 - 8 0 \mathbf { c m }}$ & $\mathbf{8 1 - 1 2 0} \mathbf{c m}$ & $\mathbf{1 2 0} \mathbf{c m}$ & $\mathbf{N}^{\circ}$ Total \\
\hline Blocos & 3 & 0,31 & 0,67 & 0,26 & 60,33 \\
Variedades (V) & 2 & 0,72 & 0,51 & 0,10 & 75,80 \\
Residuo (a) & 6 & 0,57 & 0,25 & 0,08 & 19,33 \\
\hline Parcelas & $(11)$ & - & - & - & - \\
\hline Tratamentos & 4 & 0,49 & $1,61^{\star \star}$ & $1,47^{\star \star}$ & $89,90^{\star \star}$ \\
Vx T & 8 & 0,18 & $0,91^{\star \star}$ & $0,69^{\star \star}$ & $61,73^{\star}$ \\
Resíduo (b) & 36 & 0,33 & 0,24 & 0,17 & 20,34 \\
\hline Total & 59 & - & - & - & - \\
\hline
\end{tabular}


c) Médias observadas e respectivas diferenças minimas significativas calculadas pelo método de Tukey, para variedades e tratamentos, relativas ao número de falhas de plantio.

\begin{tabular}{|c|c|c|c|c|}
\hline \multirow{2}{*}{$\begin{array}{c}\text { Médias } \\
\text { Variedades }\end{array}$} & \multicolumn{3}{|c|}{$\sqrt{N^{0} \text { falhas }+1}$} & \multirow{2}{*}{$\begin{array}{c}\text { Número } \\
\text { Total }\end{array}$} \\
\hline & $50-80 \mathrm{~cm}$ & $81-120 \mathrm{~cm}$ & $>120 \mathrm{~cm}$ & \\
\hline NA56-79 & 4 & 2 & 1 & 18 \\
\hline RB725828 & 4 & 2 & 2 & 17 \\
\hline RB735275 & 3 & 2 & 1 & 14 \\
\hline$\Delta(5 \%)$ & 1 & 1 & 1 & 4 \\
\hline \multicolumn{5}{|l|}{ Tratamentos } \\
\hline $3 G$ & 4 & 2 & 2 & 19 \\
\hline $3 G+B$ & 3 & 2 & 1 & 13 \\
\hline 6G & 4 & 2 & 1 & 15 \\
\hline CTS & 3 & 2 & 1 & 14 \\
\hline CINT & 3 & 3 & 2 & 19 \\
\hline$\Delta(5 \%)$ & 1 & 1 & 1 & 5 \\
\hline CV\% (V) & 21,8 & 24,9 & 20,5 & 26,9 \\
\hline CV\% (T) & 16,6 & 24,5 & 29,0 & 27,6 \\
\hline
\end{tabular}

$3 G=3$ Gemas; $3 G+B=3$ Gemas + Benlate $6 \mathrm{G}=6$ Gemas $; C T S=$ Corte no Terço Superior; CINT = Cana Inteira 
Apêndice 6. Dados coletados e análise de variância para a avaliação do comprimento das falhas observadas - dados transformados em $\sqrt{x+1}$, exceto para comprimento total de falhas, onde os dados não sofreram transformação.

a) Comprimento total $(\mathrm{cm})$ das falhas observadas aos 195 dias do plantio

\begin{tabular}{|c|c|c|c|c|c|c|c|c|c|c|c|c|c|c|c|}
\hline \multirow[t]{2}{*}{ Rep } & \multicolumn{3}{|c|}{$3 G$} & \multicolumn{3}{|c|}{$3 G+B$} & \multicolumn{3}{|c|}{$6 \mathrm{G}$} & \multicolumn{3}{|c|}{ CTS } & \multicolumn{3}{|c|}{ CINT } \\
\hline & $\begin{array}{l}50 \\
80 \mathrm{~cm}\end{array}$ & $\begin{array}{l}81 \\
120 \mathrm{~cm}\end{array}$ & $120 \mathrm{~cm}$ & $\begin{array}{l}50 \\
80 \mathrm{~cm} \\
\end{array}$ & $\begin{array}{l}81 \\
120 \mathrm{~cm}\end{array}$ & $120 \mathrm{~cm}$ & $\begin{array}{l}50 \\
80 \mathrm{~cm}\end{array}$ & $\begin{array}{l}81 \\
120 \mathrm{~cm}\end{array}$ & $120 \mathrm{~cm}$ & $\begin{array}{l}50 \\
80 \mathrm{~cm}\end{array}$ & $\begin{array}{l}81 \\
120 \mathrm{~cm}\end{array}$ & $120 \mathrm{~cm}$ & $\begin{array}{l}50 \\
80 \mathrm{~cm}\end{array}$ & $\begin{array}{l}81 \\
120 \mathrm{~cm}\end{array}$ & $\begin{array}{l}720 \mathrm{~cm} \\
\end{array}$ \\
\hline & \multicolumn{15}{|c|}{ NA56-79 } \\
\hline 1 & 822 & 272 & 0 & 620 & 217 & 0 & 886 & 219 & 0 & 965 & 689 & 132 & 423 & 947 & 956 \\
\hline 2 & 707 & 369 & 128 & 1009 & 196 & 0 & 1300 & 367 & 0 & 770 & 406 & 146 & 825 & 1026 & 627 \\
\hline 3 & 798 & 0 & 0 & 407 & 191 & 0 & 776 & 195 & 0 & 913 & 373 & 0 & 7003 & 457 & 1066 \\
\hline & 770 & 500 & 140 & 770 & 0 & 0 & 520 & 225 & 0 & 892 & 412 & 130 & 980 & 405 & $6 \infty 0$ \\
\hline \multirow[t]{2}{*}{ Total } & 3097 & 1141 & 268 & 2806 & $\infty 04$ & 0 & 3482 & 1006 & 0 & 3540 & 1880 & 408 & 2931 & 2835 & 3300 \\
\hline & \multicolumn{15}{|c|}{ RB725828 } \\
\hline 1 & 619 & 499 & 581 & 851 & 384 & 499 & 829 & 349 & 0 & 686 & 200 & 0 & 610 & 1347 & 0 \\
\hline 2 & 115 & 484 & 487 & 658 & 407 & 579 & 1000 & 0 & 0 & 215 & 179 & 0 & $\approx 24$ & 426 & 1319 \\
\hline 3 & 817 & 100 & $\$ 30$ & 234 & 409 & 0 & 1092 & 0 & 0 & 866 & 179 & 0 & 723 & 758 & 0 \\
\hline & 901 & 890 & 1131 & 283 & 0 & 0 & 533 & 100 & 0 & 629 & 245 & 0 & 833 & 675 & 270 \\
\hline \multirow[t]{2}{*}{ Total } & 3490 & 1973 & 2879 & 2026 & 1200 & 1078 & 3584 & 449 & 0 & 2306 & 812 & 0 & 2790 & 3206 & 1589 \\
\hline & \multicolumn{15}{|c|}{ RB735275 } \\
\hline 1 & $7 \sqrt[3]{ }$ & 817 & 0 & 1075 & 396 & 501 & 1008 & 81 & 121 & 992 & 90 & 132 & 742 & 0 & 138 \\
\hline 2 & 328 & 538 & 866 & 783 & 760 & 250 & 348 & 172 & 0 & 467 & 192 & 0 & 638 & 303 & 150 \\
\hline 3 & 695 & 675 & 0 & 603 & 84 & 0 & 445 & 83 & 130 & 328 & 0 & 0 & 265 & 279 & 134 \\
\hline 4 & 878 & 292 & 431 & 176 & 0 & 134 & 1055 & 83 & 0 & 533 & 273 & 0 & 645 & 94 & 234 \\
\hline Total & 2664 & 2372 & 1297 & 2637 & 1240 & 885 & 2856 & 419 & 251 & 2320 & 555 & 132 & 2290 & 676 & 656 \\
\hline
\end{tabular}

b) Análise de Variância

\begin{tabular}{lccccc}
\hline C.Variaçao & G.L. & \multicolumn{5}{c}{ Quadrados Médios } \\
\cline { 3 - 6 } & & $\mathbf{5 0 - 8 0 \mathbf { c m }}$ & $\mathbf{8 1 - 1 2 0} \mathbf{c m}$ & $\mathbf{1 2 0} \mathbf{c m}$ & $\mathbf{N}^{\circ}$ Total \\
\hline Blocos & 3 & 25,81 & 114,34 & 118,79 & 720501,12 \\
Variedades (V) & 2 & 59,02 & 83,65 & 17,89 & $541706,31^{\star \star}$ \\
Residuo (a) & 6 & 37,43 & 39,48 & 22,00 & 40510,89 \\
\hline Parcelas & $(11)$ & - & - & - & - \\
\hline Tratamentos & 4 & 33,59 & $230,82^{\star \star}$ & $539,10^{\star \star}$ & $1273286,47^{\star \star}$ \\
V $\times$ T & 8 & 13,63 & $139,11^{\star \star}$ & $246,30^{\star \star}$ & $676771,83^{\star \star}$ \\
Resíduo (b) & 36 & 26,55 & 45,00 & 61,89 & 161549,75 \\
\hline Total & 59 & - & - & - & - \\
\hline
\end{tabular}


c) Médias observadas e respectivas diferenças mínimas significativas calculadas pelo método de Tukey, para variedades e tratamentos, relativas ao comprimento total das falhas do plantio.

\begin{tabular}{|c|c|c|c|c|}
\hline Médias & \multicolumn{3}{|c|}{$\sqrt{\text { comprimento das falhas }+1}$} & \multirow{2}{*}{$\begin{array}{c}\text { Comprimento } \\
\text { Total }(\mathrm{cm})\end{array}$} \\
\hline Variedades & $50-80 \mathrm{~cm}$ & $81-120 \mathrm{~cm}$ & $>120 \mathrm{~cm}$ & \\
\hline NA56-79 & 28 & 18 & 9 & 1320 \\
\hline RB725828 & 26 & 17 & 11 & 1369 \\
\hline RB735275 & 25 & 14 & 10 & 1062 \\
\hline$\Delta(5 \%)$ & 7 & 7 & 5 & 195 \\
\hline \multicolumn{5}{|l|}{ Tratamentos } \\
\hline $3 G$ & 28 & 20 & 15 & 1598 \\
\hline $3 G+B$ & 24 & 14 & 9 & 1040 \\
\hline 6G & 28 & 11 & 3 & 996 \\
\hline CTS & 26 & 15 & 5 & 1004 \\
\hline CINT & 26 & 22 & 18 & 1615 \\
\hline$\Delta(5 \%)$ & 4 & 5 & 6 & 472 \\
\hline CV\% (V) & 23,2 & 38,4 & 47,1 & 16,1 \\
\hline CV\% (T) & 19,6 & 41,0 & 79,0 & 32,1 \\
\hline
\end{tabular}

$3 G=3$ Gemas; $3 G+B=3$ Gemas + Benlate; $6 \mathrm{G}=6$ Gemas; CTS = Corte no Terço Superior; CINT = Cana Inteira 
Apêndice 7. Medidas para a análise do número de colmos industrializáveis ( $n^{\circ}$ de colmos por parcela).

\begin{tabular}{|c|c|c|c|c|c|c|}
\hline \multicolumn{7}{|c|}{ CANA-PLANTA } \\
\hline Variedade & Tratamentos & B1 & B2 & B3 & B4 & Média \\
\hline \multirow{5}{*}{ NA56-79 } & $3 G$ & 479 & 463 & 485 & 517 & 486 \\
\hline & $3 G+B$ & 455 & 483 & 528 & 477 & 486 \\
\hline & $6 \mathrm{G}$ & 564 & 548 & 530 & 519 & 540 \\
\hline & CTS & 479 & 480 & 485 & 531 & 494 \\
\hline & CINT & 534 & 538 & 574 & 473 & 530 \\
\hline \multirow{5}{*}{ RB725828 } & $3 G$ & 493 & 419 & 453 & 418 & 446 \\
\hline & $3 G+B$ & 570 & 525 & 616 & 570 & 570 \\
\hline & $6 G$ & 586 & 574 & 576 & 594 & 583 \\
\hline & CTS & 645 & 560 & 590 & 631 & 607 \\
\hline & CINT & 594 & 586 & 553 & 600 & 583 \\
\hline \multirow{5}{*}{ RB735275 } & $3 G$ & 557 & 471 & 526 & 457 & 503 \\
\hline & $3 G+B$ & 495 & 466 & 555 & 538 & 514 \\
\hline & $6 G$ & 573 & 547 & 545 & 547 & 553 \\
\hline & CTS & 527 & 550 & 564 & 600 & 560 \\
\hline & CINT & 560 & 565 & 583 & 553 & 565 \\
\hline \multicolumn{7}{|c|}{ CANA-SOCA } \\
\hline \multirow{5}{*}{ NA56-79 } & $3 G$ & 573 & 624 & 636 & 638 & 618 \\
\hline & $3 G+B$ & 605 & 637 & 655 & 658 & 639 \\
\hline & $6 \mathrm{G}$ & 654 & 636 & 649 & 644 & 646 \\
\hline & CTS & 618 & 579 & 601 & 612 & 603 \\
\hline & CINT & 600 & 602 & 670 & 579 & 613 \\
\hline \multirow{5}{*}{ RB725828 } & $3 G$ & 643 & 505 & 561 & 645 & 589 \\
\hline & $3 G+B$ & 629 & 628 & 724 & 691 & 668 \\
\hline & $6 G$ & 655 & 637 & 688 & 600 & 645 \\
\hline & CTS & 721 & 665 & 663 & 627 & 669 \\
\hline & CINT & 679 & 613 & 647 & 636 & 644 \\
\hline \multirow{5}{*}{ RB735275 } & $3 G$ & 695 & 608 & 671 & 593 & 642 \\
\hline & $3 G+B$ & 653 & 580 & 752 & 673 & 665 \\
\hline & $6 G$ & 697 & 661 & 666 & 668 & 673 \\
\hline & CTS & 664 & 657 & 690 & 664 & 669 \\
\hline & CINT & 732 & 709 & 714 & 690 & 711 \\
\hline
\end{tabular}

$3 G=3$ Gemas; $3 G+B=3$ Gemas + Benlate $6 \mathrm{G}=6$ Gemas $; C T S=$ Corte no Terço Superior; CINT = Cana Inteira 
Apêndice 8. Dados coletados e análise de variância para número de colmos industrializáveis ( $n^{\circ}$ colmos/parcela).

a) Análise de Variância - Cana-Planta

\begin{tabular}{lcc}
\hline \multicolumn{1}{c}{ C. Variação } & G.L. & Q.M. \\
\hline Blocos & 3 & \\
Variedades (V) & 2 & $12431,45^{\star \star}$ \\
Residuo (a) & 6 & 700,65 \\
\hline Parcelas & 11 & $15393,80^{\star \star}$ \\
\hline Tratamentos (T) & 4 & $4271,84^{\star \star}$ \\
V $\times$ T & 8 & 904,91 \\
Residuo (b) & 36 & \\
\hline Total & 59 & \\
\hline
\end{tabular}

b) Análise de Variância - Cana-Soca

\begin{tabular}{lcc}
\multicolumn{1}{c}{ C. Variação } & G.L. & Q.M. \\
\hline Blocos & 3 & \\
Variedades (V) & 2 & $11843,81^{\star}$ \\
Residuo (a) & 6 & 1120,57 \\
\hline Parcelas & 11 & \\
\hline Tratamentos (T) & 4 & $3586,18^{\star}$ \\
V X T & 8 & 2265,04 n.s. \\
Residuo (b) & 36 & 1227,25 \\
\hline Total & 59 & \\
\hline
\end{tabular}


c) Médias observadas e respectivas diferenças mínimas significativas calculadas pelo método de Tukey, para variedades e tratamentos, relativas ao número de colmos industrializáveis $\left(n^{\circ}\right.$ colmos/parcela).

\begin{tabular}{lcc}
\hline & \multicolumn{2}{c}{ Número de colmos industrializáveis } \\
\cline { 2 - 3 } Variedades & Cana-Planta & Cana-Soca \\
\hline RB725828 & 556 & 643 \\
RB735275 & 539 & 672 \\
NA56-79 & 507 & 624 \\
\hline$\Delta(5 \%)$ & 26 & 33 \\
\hline Tratamentos & & \\
\hline $3 G$ & 559 & 656 \\
3G + B & 559 & 655 \\
6G & 554 & 647 \\
CTS & 523 & 657 \\
CINT & 476 & 616 \\
\hline$\Delta(5 \%)$ & 35 & 41 \\
\hline CV\% (V) & 2,2 & 2,3 \\
CV\% (T) & 5,6 & 5,4 \\
\hline
\end{tabular}

$3 G=3$ Gemas; $3 G+B=3$ Gemas + Benlate; $6 \mathrm{G}=6$ Gemas; $C T S=$ Corte no Terço Superior; $\mathrm{CINT}=$ Cana Inteira 
Apêndice 9. Medidas para a análise do rendimento agrícola - t/ha (peso das parcelas em $\mathrm{kg}$ )

\begin{tabular}{|c|c|c|c|c|c|c|}
\hline \multicolumn{7}{|c|}{ CANA-PLANTA } \\
\hline Variedade & Tratamentos & B1 & B2 & B3 & B4 & Média \\
\hline \multirow{5}{*}{ NA56-79 } & $3 G$ & 650 & 635 & 700 & 715 & 675 \\
\hline & $3 G+B$ & 650 & 695 & 725 & 620 & 673 \\
\hline & $6 G$ & 825 & 810 & 775 & 815 & 806 \\
\hline & CTS & 705 & 705 & 785 & 810 & 751 \\
\hline & CINT & 890 & 810 & 915 & 695 & 828 \\
\hline \multirow{5}{*}{ RB725828 } & $3 G$ & 615 & 425 & 595 & 475 & 528 \\
\hline & $3 G+B$ & 675 & 660 & 785 & 690 & 703 \\
\hline & $6 G$ & 750 & 740 & 750 & 680 & 730 \\
\hline & CTS & 855 & 690 & 765 & 775 & 771 \\
\hline & CINT & 830 & 740 & 705 & 765 & 760 \\
\hline \multirow{5}{*}{ RB735275 } & $3 G$ & 955 & 775 & 855 & 760 & 836 \\
\hline & $3 G+B$ & 815 & 735 & 890 & 845 & 821 \\
\hline & $6 G$ & 965 & 905 & 890 & 920 & 920 \\
\hline & CTS & 945 & 910 & 1030 & 1035 & 980 \\
\hline & CINT & 1120 & 1030 & 1050 & 960 & 1040 \\
\hline \multicolumn{7}{|c|}{ CANA-SOCA } \\
\hline \multirow{5}{*}{ NA56-79 } & $3 G$ & 779 & 832 & 888 & 918 & 854 \\
\hline & $3 G+B$ & 794 & 842 & 930 & 886 & 863 \\
\hline & $6 \mathrm{G}$ & 941 & 947 & 893 & 906 & 922 \\
\hline & CTS & 850 & 749 & 825 & 948 & 843 \\
\hline & CINT & 852 & 865 & 971 & 823 & 878 \\
\hline \multirow{5}{*}{ RB725828 } & $3 G$ & 838 & 625 & 788 & 745 & 749 \\
\hline & $3 G+B$ & 844 & 856 & 949 & 802 & 863 \\
\hline & 6G & 833 & 899 & 932 & 819 & 871 \\
\hline & CTS & 995 & 847 & 895 & 905 & 911 \\
\hline & CINT & 932 & 801 & 905 & 925 & 891 \\
\hline \multirow{5}{*}{ RB735275 } & $3 G$ & 980 & 1088 & 950 & 905 & 961 \\
\hline & $3 G+B$ & 972 & 877 & 969 & 895 & 928 \\
\hline & $6 \mathrm{G}$ & 1024 & 1019 & 1002 & 1034 & 1020 \\
\hline & CTS & 975 & 1005 & 1034 & 1088 & 1026 \\
\hline & CINT & 1125 & 1103 & 1061 & 1089 & 1095 \\
\hline
\end{tabular}

$3 G=3$ Gemas; $3 G+B=3$ Gemas + Benlate; $6 G=6$ Gemas; $C T S=$ Corte no Terço Superior; CINT = Cana Inteira 
Apêndice 10. Dados coletados e análise de variância para rendimento agrícola (peso das parcelas em $\mathrm{kg}$ ).

a) Análise de Variância - Cana-Planta

\begin{tabular}{lcc}
\multicolumn{1}{c}{ C. Variação } & G.L. & Q.M. \\
\hline Blocos & 3 & \\
Variedades (V) & 2 & $270695,41^{\star \star}$ \\
Resíduo (a) & 6 & 1866,52 \\
\hline Parcelas & 11 & $77017,29^{\star \star}$ \\
\hline Tratamentos (T) & 4 & $8906,35^{\star}$ \\
V $\times$ T & 8 & 3520,27 \\
Residuo (b) & 36 & \\
\hline Total & 59 & \\
\hline
\end{tabular}

b) Análise de Variância - Cana-Soca

\begin{tabular}{lcc}
\multicolumn{1}{c}{ C. Variação } & G.L. & Q.M. \\
\hline Blocos & 3 & \\
Variedades (V) & 2 & $134448,26^{\star \star \star}$ \\
Residuo (a) & 6 & 4001,13 \\
\hline Parcelas & 11 & $20029,35^{\star \star}$ \\
\hline Tratamentos (T) & 4 & $8048,41^{\star}$ \\
V x T & 8 & 2921,26 \\
Resíduo (b) & 36 & \\
\hline Total & 59 & \\
\hline
\end{tabular}


c) Médias observadas e respectivas diferenças mínimas significativas calculadas pelo método de Tukey, para variedades e tratamentos, relativas à produtividade agrícola (peso das parcelas em $\mathrm{kg}$ )

\begin{tabular}{lcc} 
& Produtividade Agrícola (peso/parcela-kg) \\
\cline { 2 - 3 } Variedades & Cana-Planta & Cana-Soca \\
\hline RB735275 & 919,50 & 1005,75 \\
NA56-79 & 746,50 & 871,95 \\
RB725828 & 698,25 & 856,75 \\
\hline$\Delta(5 \%)$ & & 61 \\
\hline Tratamentos & & \\
\hline CINT & 875,83 & 954,33 \\
CTS & 834,16 & 926,33 \\
6G & 818,75 & 937,41 \\
3G +B & 732,08 & 884,66 \\
3G & 679,58 & 854,66 \\
\hline$\Delta(5 \%)$ & 67 & 63 \\
\hline CV\% (V) & 2,5 & 3,1 \\
CV\% (T) & 7,2 & 5,0 \\
\hline
\end{tabular}

$3 G=3$ Gemas; $3 G+B=3$ Gemas + Benlate; $6 G=6$ Gemas; $C T S=$ Corte no Terço Superior; CINT = Cana Inteira 
Apêndice 11. Análises de Variância para Estudo de Regressão

a) Para Cana-Planta

\begin{tabular}{|c|c|c|c|c|}
\hline \multirow{3}{*}{$\begin{array}{l}\text { Causas da } \\
\text { Variação }\end{array}$} & \multirow{3}{*}{ G.L. } & \multicolumn{3}{|c|}{ Variedades } \\
\hline & & NA56-79 & RB725828 & RB735275 \\
\hline & & Q.M. & Q.M. & Q.M. \\
\hline Regressão & 1 & $51886,50^{\star \star}$ & $82521,11^{\star \star}$ & $120308,31^{\text {** }}$ \\
\hline Resíduo & 18 & 4542,69 & 7510,70 & 4629,81 \\
\hline Total & 19 & & & \\
\hline
\end{tabular}

b) Para Cana-Soca

\begin{tabular}{lcccc} 
Causas da & & \multicolumn{3}{c}{ Variedades } \\
\cline { 3 - 5 } Variação & G.L. & NA56-79 & RB725828 & RB735275 \\
\cline { 3 - 5 } & & Q.M. & Q.M. & Q.M. \\
\hline Regressão & 1 & 267,16 n.S. & $32664,69^{\star}$ & $53832,48^{\star \star}$ \\
Resíduo & 18 & 3951,65 & 5470,72 & 1939,84 \\
\hline Total & 19 & & & \\
\hline
\end{tabular}

c) Para Cana-Planta - Média Geral das Variedades

\begin{tabular}{lcc}
\hline Causas da Variação & G.L. & Q.M. \\
\hline Regressão & 1 & $87682,94^{\text {*ૌ }}$ \\
Resíduo & 18 & 2768,82 \\
\hline Total & 19 & \\
\hline
\end{tabular}

d) Para Cana-Soca - Média Geral das Variedades

\begin{tabular}{lcc}
\hline Causas da Variação & GL & QM \\
\hline Regressão & 1 & $20460,24^{\star \star}$ \\
Resíduo & 18 & 1264,38 \\
Total & 19 & \\
\hline
\end{tabular}

